\title{
An Archaeological Survey of 90 Acres at Camp Bowie, Brown County, Texas
}

\author{
Raymond P. Mauldin \\ Center for Archeological Research, University of Texas at San Antonio
}

Cory J. Broehm

Follow this and additional works at: https://scholarworks.sfasu.edu/ita

Part of the American Material Culture Commons, Archaeological Anthropology Commons, Environmental Studies Commons, Other American Studies Commons, Other Arts and Humanities Commons, Other History of Art, Architecture, and Archaeology Commons, and the United States History Commons

Tell us how this article helped you.

This Article is brought to you for free and open access by the Center for Regional Heritage Research at SFA ScholarWorks. It has been accepted for inclusion in Index of Texas Archaeology: Open Access Gray Literature from the Lone Star State by an authorized editor of SFA ScholarWorks. For more information, please contact cdsscholarworks@sfasu.edu. 


\section{An Archaeological Survey of 90 Acres at Camp Bowie, Brown County, Texas}

Creative Commons License

(c) (i) (8)

This work is licensed under a Creative Commons Attribution-NonCommercial 4.0 International License 


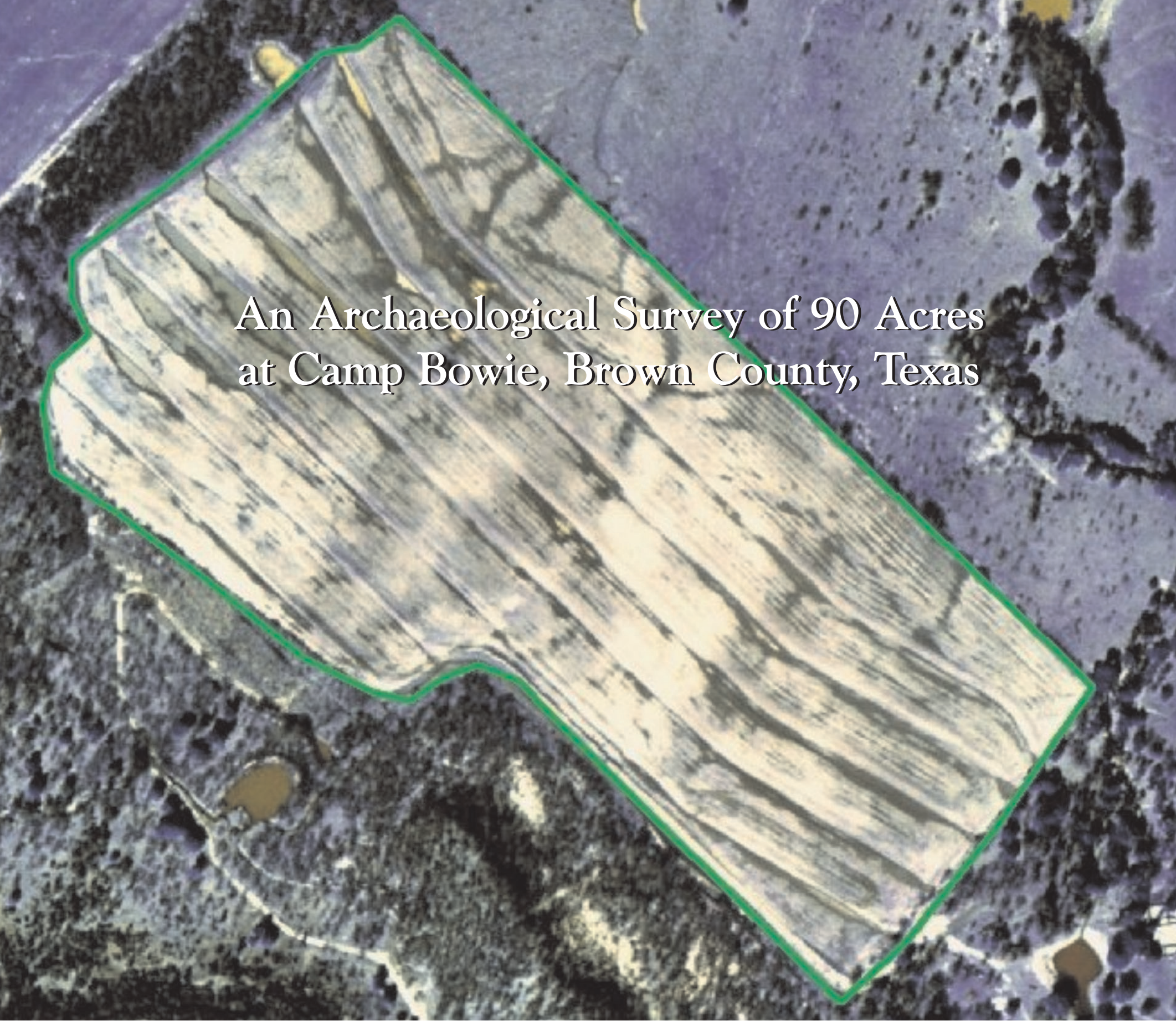

by

Raymond P. Mauldin and Cory J. Broehm

The Adjutant General's Department of Texas Directorate of Facilities and Engineering Environmental Branch, Austin, Texas
Center for Archaeological Research The University of Texas at San Antonio Archaeological Survey Report, No. 319 


\title{
An Archaeological Survey of 90 Acres at Camp Bowie, Brown County, Texas
}

\author{
Raymond P. Mauldin and Cory J. Broehm
}

\author{
Raymond P. Mauldin \\ Principal Investigator
}

Texas Antiquities Permit No. 2310

Prepared for:

The Adjutant General's Department of Texas

Directorate of Facilities and Engineering Environmental Branch, Austin, Texas
Prepared by:

Center for Archaeological Research The University of Texas at San Antonio Archaeological Survey Report, No. 319 
The following information is provided in accordance with the General Rules of Practice and Procedure, Chapter 41.11 (Investigative Reports), Texas Antiquities Committee:

1. Type of investigation: Pedestrian survey and shovel testing

2. Project name: Camp Bowie 90-acre Survey

3. County: Brown

4. Principal investigator: Raymond P. Mauldin

5. Name and location of sponsoring agency: Adjutant General's Department of Texas, Cultural Resources Program, Austin, Texas.

6. Texas Antiquities Permit No.: 2310

7. Published by the Center for Archaeological Research, The University of Texas at San Antonio, 6900 N. Loop 1604 W., San Antonio, Texas 78249-0658, 2001

A list of publications offered by the Center for Archaeological Research is available. Call (210) 458-4378; write to the Center for Archaeological Research, The University of Texas at San Antonio, 6900 N. Loop 1604 W., San Antonio, Texas 78249-0658; e-mail to car@lonestar.utsa.edu; or visit CAR's web site at http://car.utsa.edu. 


\begin{abstract}
In February, March, and May of 2001, personnel from the Center for Archaeological Research (CAR), The University of Texas at San Antonio, conducted a cultural resource inventory survey, involving pedestrian survey and shovel testing, of an approximately 90 -acre $\left(364,060 \mathrm{~m}^{2}\right)$ tract of land in a plowed field on Camp Bowie, Brown County, Texas. A total of 104 shovel tests were systematically placed within the 90 -acre area. The survey identified three prehistoric sites, all lithic scatters defined by surface material. Twelve additional shovel tests were placed on these three sites. An arrow point fragment, collected from the surface of 41BR499, suggests a Late Prehistoric affiliation for this site. Dart points collected from 41BR500 suggest a Late Archaic use of this area. Finally, an arrow point, collected from 41BR501, suggests a Late Prehistoric component at this site. In addition, a single whole mano was collected from the surface of 41BR500.

Based on the results of the pedestrian survey and the overall condition of the sites, CAR suggests that two of the sites (41BR499 and 41BR501) lack data of sufficient quality or quantity to address regional research questions. In the case of both 41BR499 and 41BR501, the sites appear to be primarily surface phenomena that have been impacted by plowing and are not recommended for inclusion in the National Register of Historic Places, or for designation as State Archeological Landmarks. In the case of 41BR500, while much of the site appears to be disturbed by plowing and trenching activities, a portion of the site situated along the edge of the field has not been disturbed. Subsurface deposits are present in this unplowed area and shovel test results, supported by high soil susceptibility values, suggest the presence of a buried feature. In addition, 41BR500 contains both high artifact density and variety, and the recovery of diagnostic projectile points suggest a Late Archaic temporal placement. As such, CAR recommends that 41BR500 is potentially eligible for inclusion to the National Register of Historic Places, and designation as a State Archeological Landmark. Further testing of this site in the undisturbed portion is recommended to determine final eligibility status.
\end{abstract}




\section{Contents}

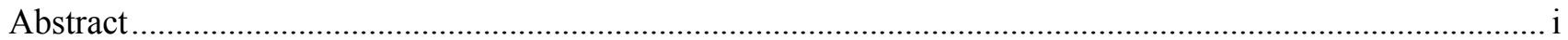

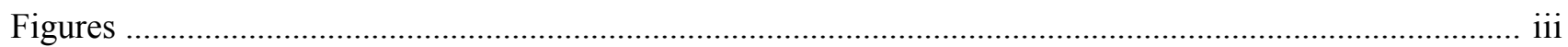

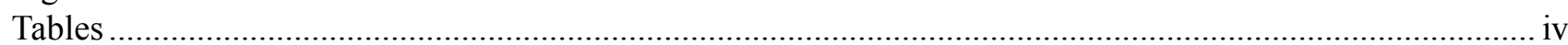

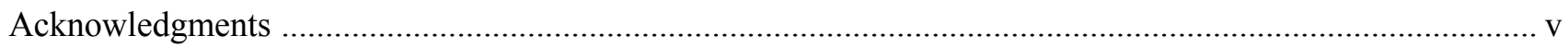

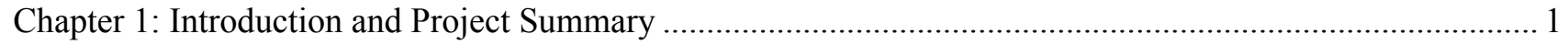

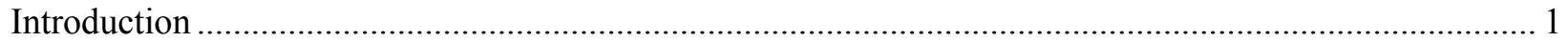

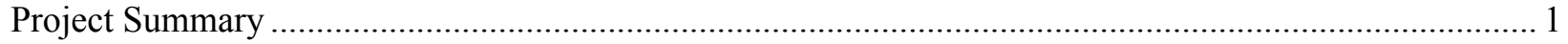

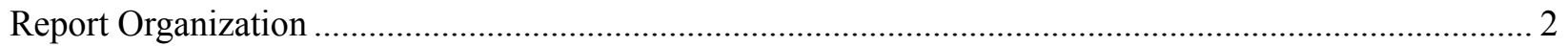

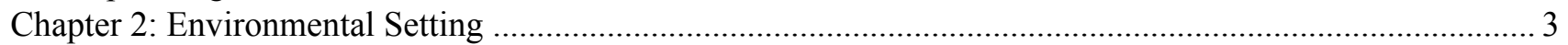

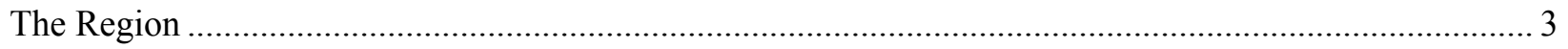

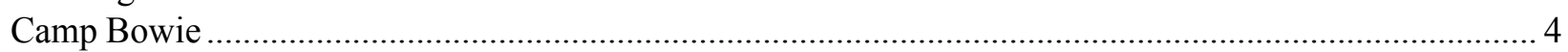

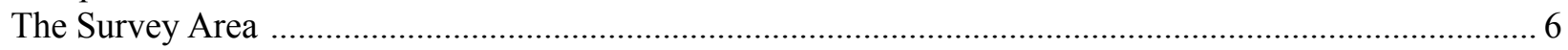

Chapter 3: Prehistoric Cultural Background and Previous Research at Camp Bowie ..................................... 9

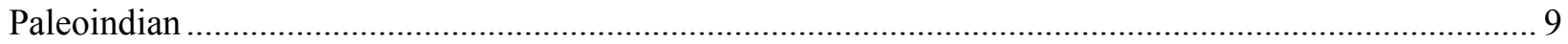

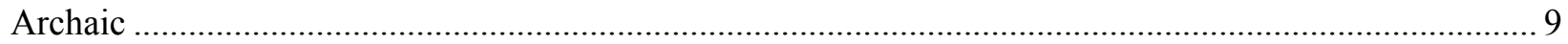

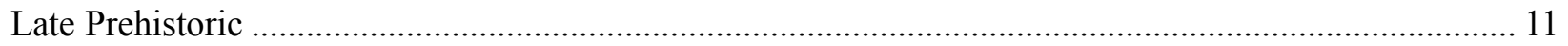

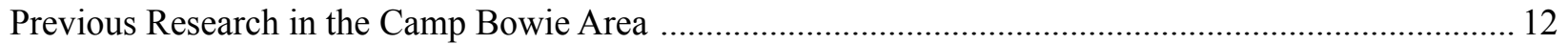

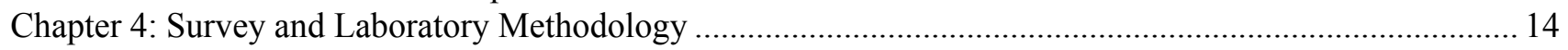

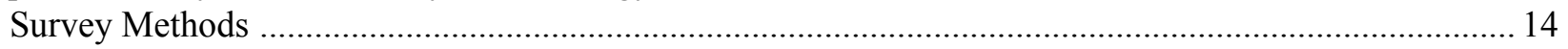

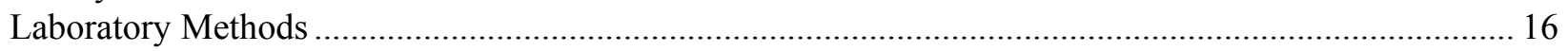

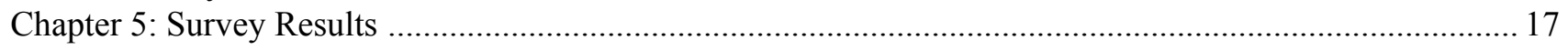

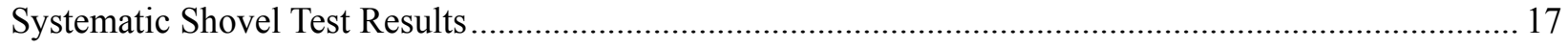

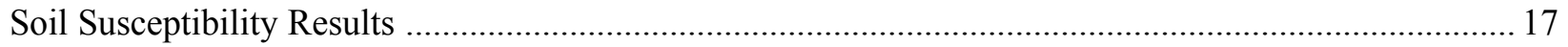

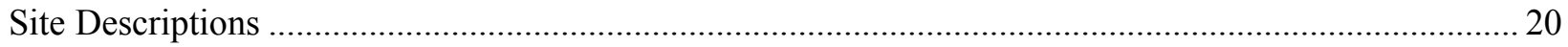

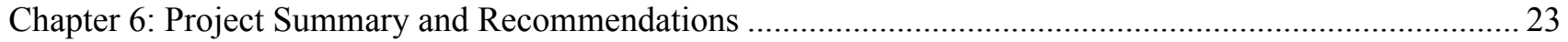

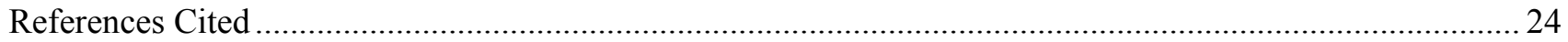

Appendix A

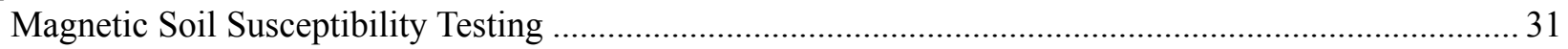




\section{Figures}

Figure 1. General location of the project area.

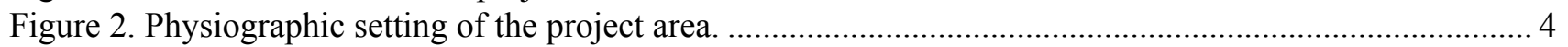

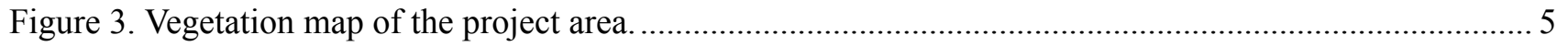

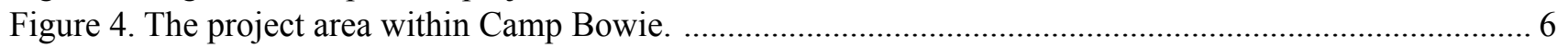

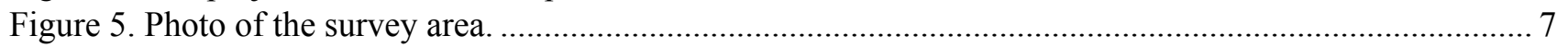

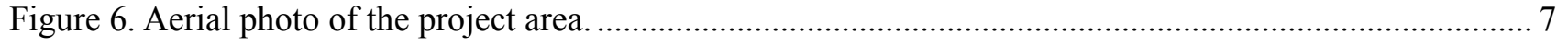

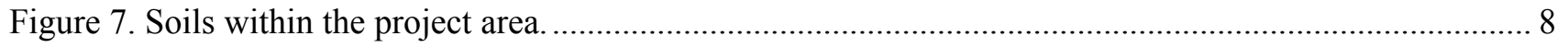

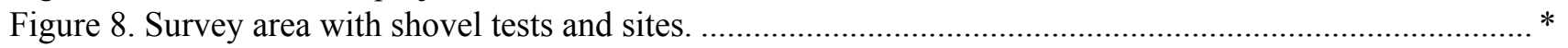

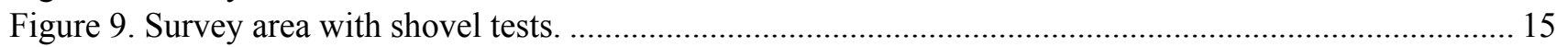

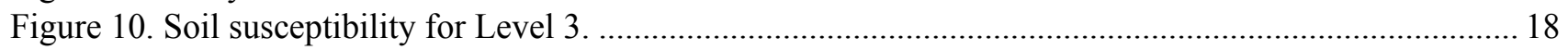

Figure 11. Comparison of soil susceptibility values for all sites with values for 41BR500, ST-7 ................ 20

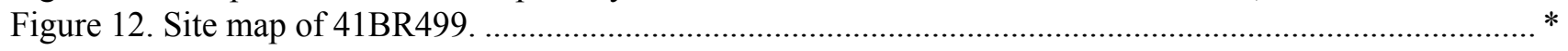

Figure 13. Selected artifacts collected from sites 41BR499, 41BR500, and 41BR501............................. 21

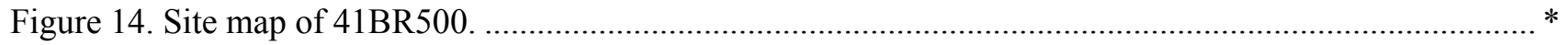

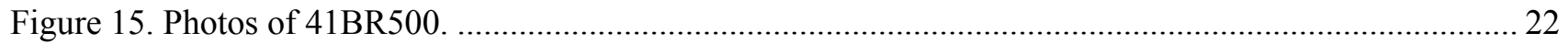

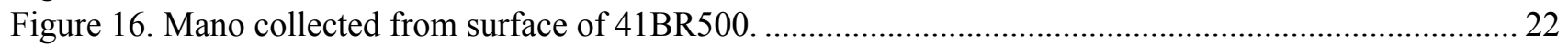

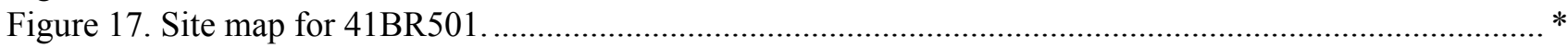

* These maps are not included in this report because of the sensitivity issues involved with archaeological sites. For those readers who are interested, these maps may be obtained by calling (512) 782-6194, or writing to AGTX-EV, Cultural Resources, P.O. Box 5218, Austin, TX 78763-5218. 


\section{Tables}

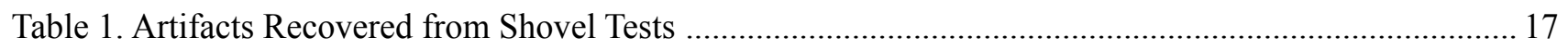

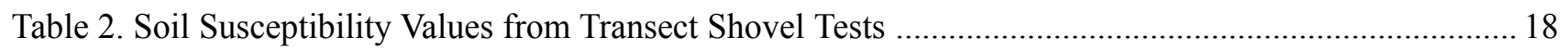

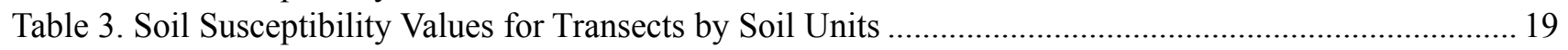

Table 4. Soil Susceptibility Values for Sites and Non-sites within the Ab Soil Unit ................................... 19

Table A-1. Magnetic Soil Susceptibility Data for a Variety of Substances ................................................... 33

Table A-2. Cultural Material and Mass Specific Soil Susceptibility Values for 41BR473 ........................... 34

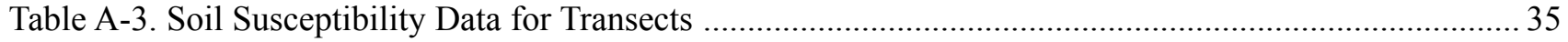

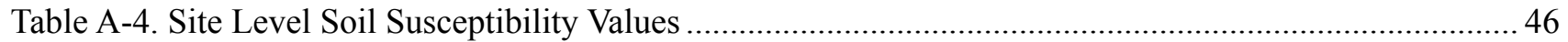




\section{Acknowledgments}

The archaeological survey was conducted by Rick Robinson, Cory Broehm, Lisa Shaddox, Raymond Mauldin, Jason Weston, Ruth Mathews, and Jennifer Logan, all of the Center for Archaeological Research (CAR) at The University of Texas at San Antonio. Raymond Mauldin directed the fieldwork and was the Principal Investigator. Rick Robinson served as crew chief. Cory Broehm and Raymond Mauldin conducted the soil susceptibility analysis. The CAR Laboratory staff, under the direction of Marybeth Tomka, processed and cataloged the artifacts. Dr. Steve Tomka assisted with projectile point identification. Rick Young and Bruce Moses produced the maps and illustrations, and the manuscript was edited by Maryanne King, Johanna Hunziker, and Jennifer Logan. Sergeant Major M. Pilkington and the Security Staff at Camp Bowie were extremely helpful in all aspects of the work. Shellie Sullo-Prewitt of the Texas Army National Guard Environmental Affairs Division provided invaluable support for this project. 



\section{Chapter 1: Introduction and Project Summary}

In February, March, and May of 2001, personnel from the Center for Archaeological Research (CAR) at The University of Texas at San Antonio (UTSA) conducted a pedestrian survey and shovel testing of an estimated 90 -acre tract of previously unsurveyed plowed land at Camp Bowie, Brown County, Texas. This work was carried out pursuant to a Specification of Services and Scope of Work produced by the Adjutant General's Department of Texas (AGTX). That document called for a cultural resource inventory survey of the tract. The survey involved locating and recording all cultural resources within the survey area, and assessing the eligibility of any sites discovered for inclusion in the National Register of Historic Places (NRHP) or as a State Archeological Landmark (SAL).

\section{Introduction}

Located in Brown County south of Brownwood, Texas, on Brownwood and Indian Creek USGS 7.5' quadrangles, Camp Bowie was developed by the Army as a training site just prior to World War II. Construction of the camp began in 1940, and by 1947, when the U.S. Army began to liquidate property, the camp was approximately 123,000 acres in size. Currently, Camp Bowie is approximately 9,000 acres in size and serves as a training site for the Texas Army National Guard (TXARNG). The 9,000-acre facility is divided between state and federally-owned land, with state acreage accounting for just over 50 percent of the camp.

Camp Bowie hosts a variety of military training activities, including tank maneuvering, small arms training, and air-drops. In addition to military uses, state owned acreage is used for cattle and sheep grazing and hunting. The construction and maintenance of stock ponds, earthen dams, firebreaks, roads, and livestock support facilities has resulted in landscape modification (Nature Conservancy of Texas 1996; Wormser and Sullo-Prewitt 2001).

\section{Project Summary}

The investigation reported here involved the survey of approximately 90 acres of previously unsurveyed, state-owned land. A total of 104 shovel tests were systematically placed within the 90 -acre survey area. During the survey three prehistoric sites, all lithic scatters with surface manifestations, were identified. Twelve additional shovel tests were placed on these three sites to explore the potential for buried deposits. Of the 116 shovel tests, only six (5.2 percent) contained prehistoric artifacts, and only 12 artifacts were recovered from subsurface context. Note that roughly 92 percent of all artifacts recovered from shovel tests were within the upper $30 \mathrm{~cm}$.

The three archaeological sites identified in the project area were defined by surface distributions of chipped and ground stone artifacts. An arrow point fragment collected from the surface of 41BR499 suggests a Late Prehistoric affiliation for this site. Three dart points collected from 41BR500 suggest a Late Archaic use of this area. Finally, an arrow point collected from 41BR501 suggests a Late Prehistoric component at this site. In all three cases, the site surfaces have been extensively disturbed by plowing, and in one case (41BR500), trenching and other earth moving activities are evident.

Based on the results of the pedestrian survey, and the overall condition of the sites, CAR suggests that two of the three sites lack data of sufficient quality or quantity to address regional research questions. Therefore, 41BR499 and 41BR501 are not recommended for inclusion in the National Register of Historic Places, or for designation as State Archeological Landmarks. In the case of 41BR500, while much of the site appears to be disturbed by plowing and trenching activities, a portion of the site is situated along the edge of the field, and thus has not been significantly disturbed. Subsurface deposits are present in this unplowed area 
and shovel test results, supported by high soil susceptibility values, suggest the presence of at least one buried feature. In addition, diagnostic projectile points recovered from the site suggest a Late Archaic temporal affiliation. The site also has high artifact density and variety. As such, CAR recommends that 41BR500 is potentially eligible for inclusion to the National Register of Historic Places, and designation as a State Archeological Landmark. Further testing of this site in the undisturbed portions is recommended to determine the eligibility status of 41BR500.

\section{Report Organization}

This report is divided into six chapters and an appendix. In addition to the current chapter, Chapter 2 provides an overview of the environment of the area. Chapter 3 provides a cultural background and a summary of recent work at Camp Bowie. Chapter 4 discusses the survey and laboratory procedures. Chapter 5 presents the results of the survey. Chapter 6 provides a summary of the project and recommendations on the three archaeological sites discovered. The results of a magnetic soil susceptibility study of sediments from shovel tests are in Appendix A.

Project maps with site-specific locations are not included within this report due to the sensitivity issues involved with archaeological sites. These maps are located in a pocket at the back of this report. If the maps are not present they may be obtained by contacting the Environmental Affairs Division of the Adjutant General's Department of Texas, Camp Mabry, Austin, Texas. 


\section{Chapter 2: Environmental Setting}

This chapter provides an introduction to the general environment of the region, as well as information on Camp Bowie and the immediate survey area. More detailed information on the climate, geology, and soils can be found in Gould (1975), Nance and Wermund (1993), and Wormser and Sullo-Prewitt (2001). Reviews of paleoenvironmental data, which are primarily available for areas farther to the south, can be found in Bousman (1998) and Johnson and Goode (1994).

\section{The Region}

The project area is located in north-central Texas, in Brown County, just south of the town of Brownwood (Figure 1). Brown County covers an area of roughly 615,000 acres (Clower 1980). The major hydrological feature is Pecan Bayou, a river that enters the county from the northwest and exits in the southeast into the Colorado River. The Colorado River forms the southern boundary of the county. Very shallow to deep, loamy and clayey soils cover the uplands of Brown County, while deep loamy and clayey soils cover the floodplains (Clower 1980).

Physiographically, the area is within the Rolling Plains subdivision (Figure 2), with the Edwards Plateau located just to the east, and the Llano Uplift located to the south (see Gould 1975; Nance and Wermund 1993). The terrain of the Rolling Plains is characterized as gently sloping to hilly as a result of varying erosion of primarily Paleozoic rock formations (Fenneman 1931:54). The Edwards Plateau has a more rugged, stream-eroded topography underlain by Cretaceous limestone. The Llano Uplift is essentially an eroded basin composed of Precambrian granitic and metamorphic rock (Swanson 1995).

Characterized as subtropical sub-humid, the climate of the area is one of hot summers and mild winters with an average yearly temperature of 65 degrees. The growing season averages about 239 days a year, with the average first freeze occurring on November 16 and the last freeze happening on March 21. Annual precipitation at Brownwood is approximately 26.1 inches $(66 \mathrm{~cm})$. The highest annual rainfall was recorded in 1959 when 42.3 inches $(107.4 \mathrm{~cm})$ of precipitation was recorded, while the driest year was 1954 with only 12.8 inches $(32.5 \mathrm{~cm})$. Within a year, rainfall tends to be bimodal, with peaks in May and September. December and January are, on average, the driest months of the year (Nance and Wermund 1993).

Figure 3 presents the regional, modern vegetation of the general area. A Live Oak, Mesquite, Ashe Juniper Parkway dominates the southwestern portion of the county, with an Oak, Mesquite, Juniper Parkway bracketing the Pecan Bayou drainage area. Silver bluestem and Texas wintergrass are present along the eastern edge of the county. Much of the county has been cleared for crops and grazing.

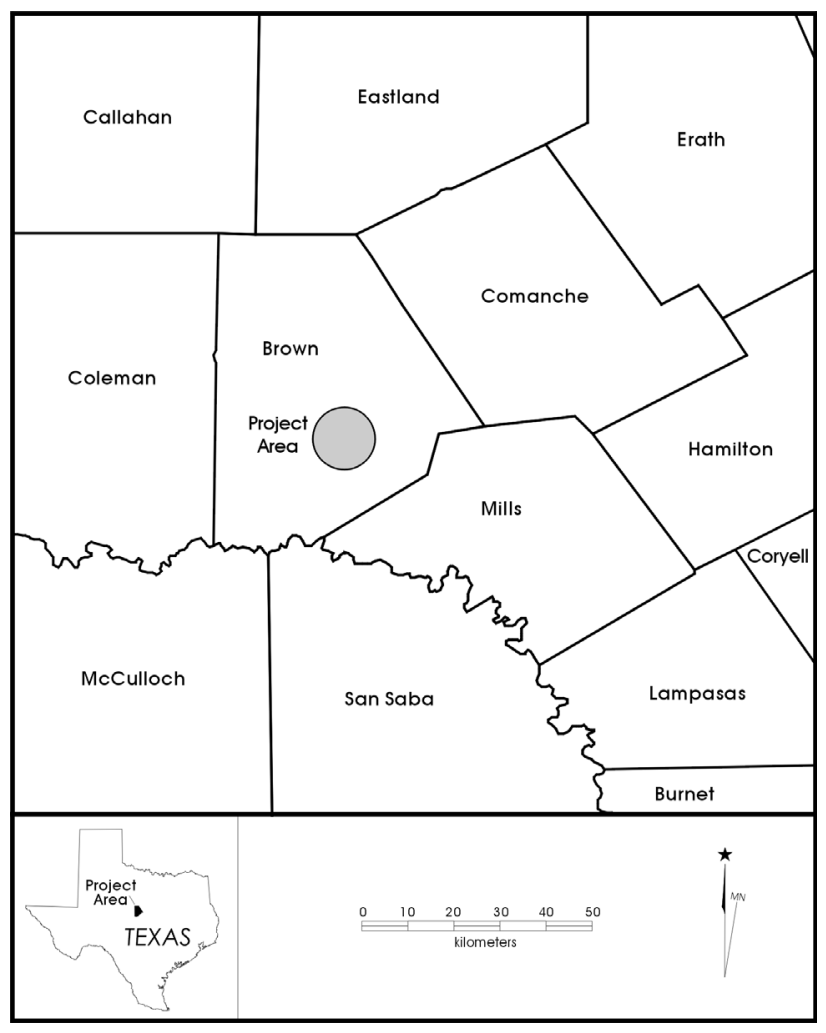

Figure 1. General location of the project area. 


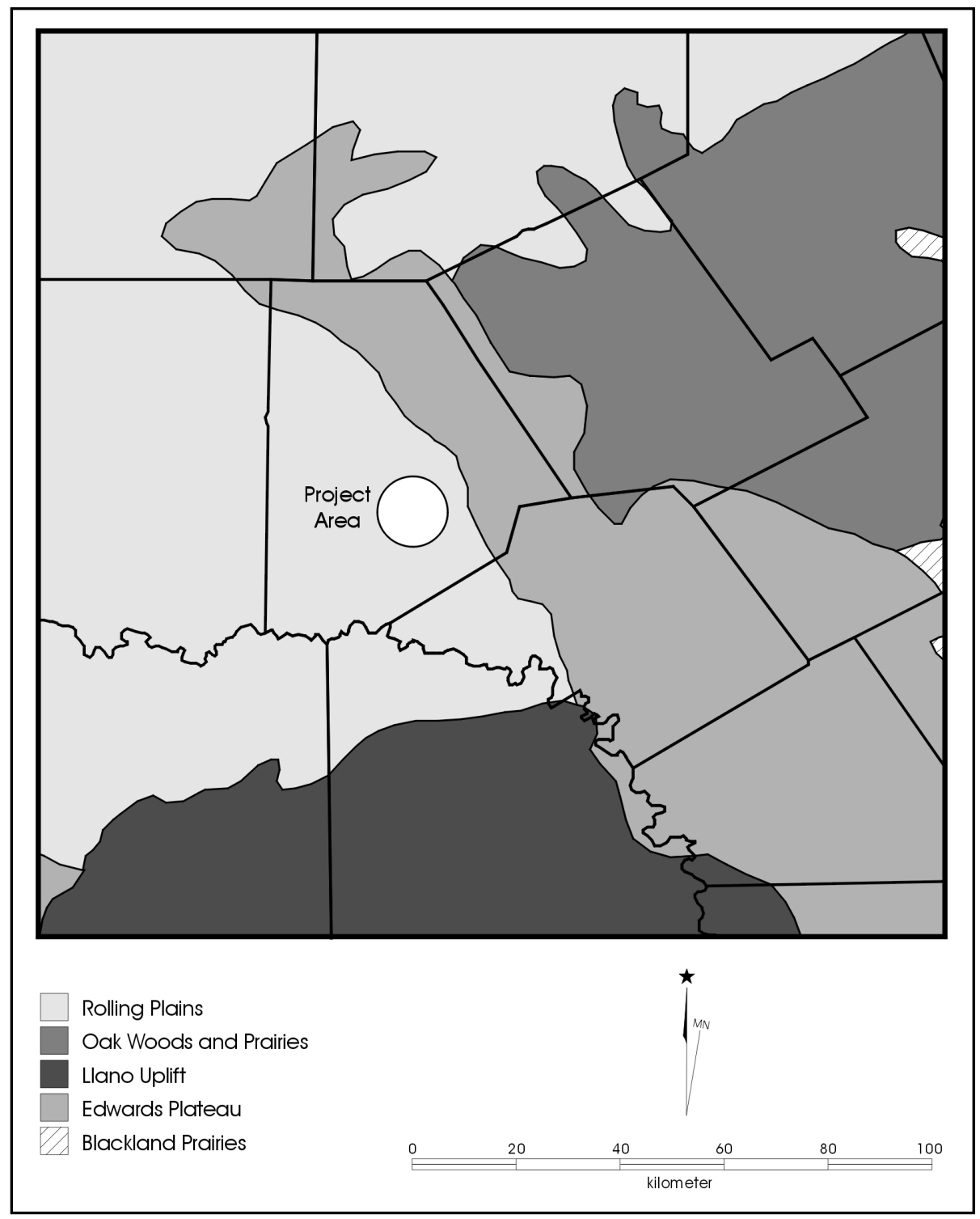

Figure 2. Physiographic setting of the project area.

\section{Camp Bowie}

Camp Bowie covers an area of approximately 9,000 acres. Elevation within the camp itself ranges from 1,290 feet (393 m) above sea level (ASL) to just over 1,590 feet (485 m) ASL. A major topographic feature of the area is a northwest to southeast oriented high ridge of Cretaceous age deposits identified as the Travis Peak Formation (Wormser and Sullo-Prewitt 2001). This major sedimentary deposit includes limestone, sandstone, and conglomerate. Underlying Permian and Pennsylvanian formations, referred to as the
Strawn Group, are exposed at various points on the landscape (Nance and Wermund 1993).

Soils of the Camp Bowie area are calcareous sandy loams, silty loams, and clay loams. Upland soils are thin and sandier, with low water-holding capacity. Lowland soils tend to be dominated by clay, with low permeability and high water-holding capacity (Nance and Wermund 1993; Wormser and Sullo-Prewitt 2001). Wormser and Sullo-Prewitt (2001) classified 


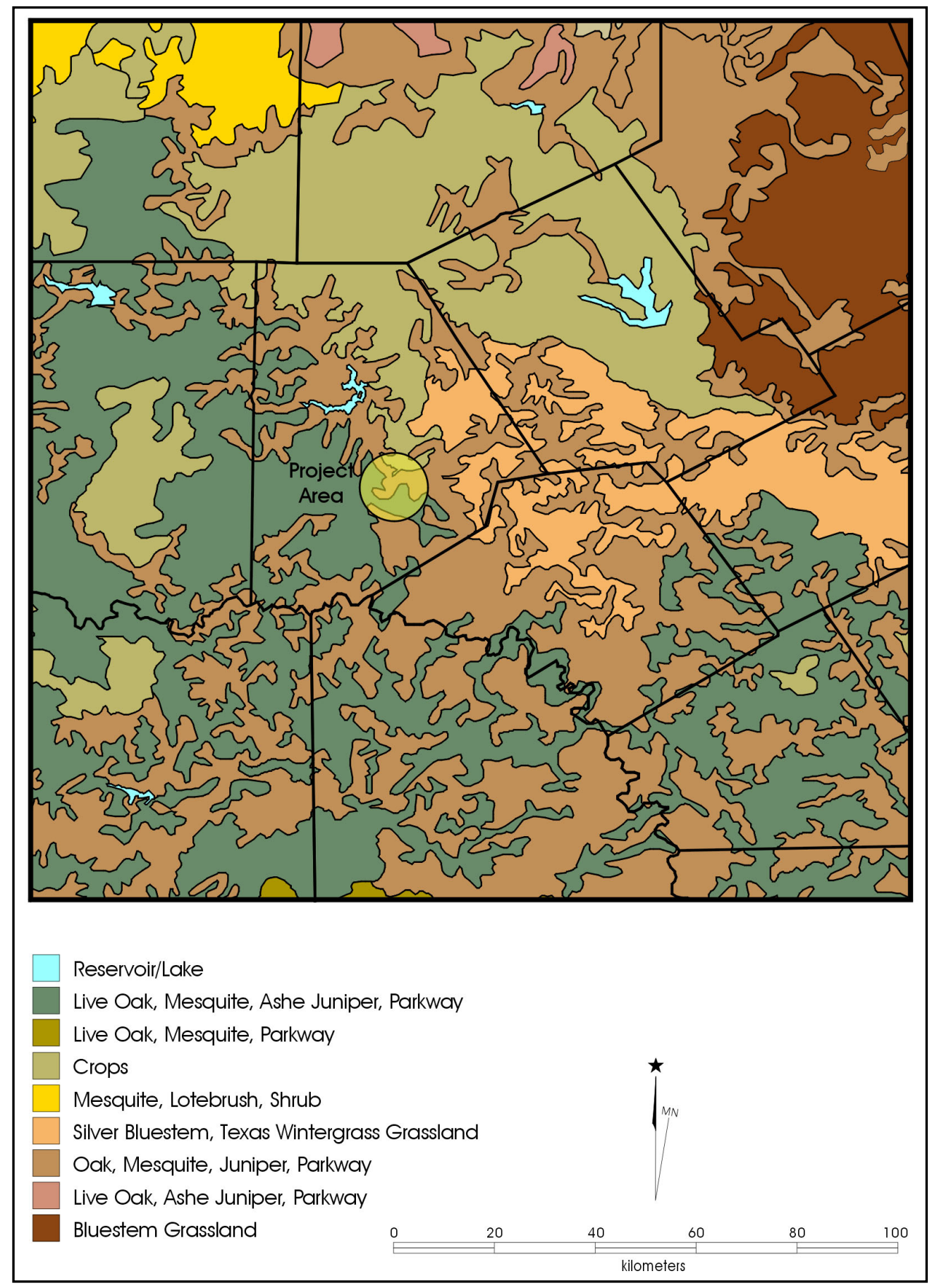

Figure 3. Vegetation map of the project area.

the USDA soil units at Camp Bowie into three general groups designed to monitor their potential to contain buried, intact cultural deposits. The tripartite distinction was based on their evaluation of the soil age and formation history. They suggest that sites on or in the Deleon, Frio, Winters, and Nukrum soils have a moderate-to-high potential for buried archeological material. Soils with low-to-moderate potential for buried, intact sites include Pedernales fine sandy loam and Sagerton clay loam. The remaining soils have a 
low probability of containing buried cultural deposits with integrity.

Streams in the Camp Bowie area make up a portion of the Colorado River drainage basin and are small and seasonally active. Drainages to the west of the northwest-southeast trending ridge that cuts through the center of the camp flow into Lewis Creek and eventually into Pecan Bayou to the north, while on the east side of the dividing ridge, drainage is generally into Devils River.

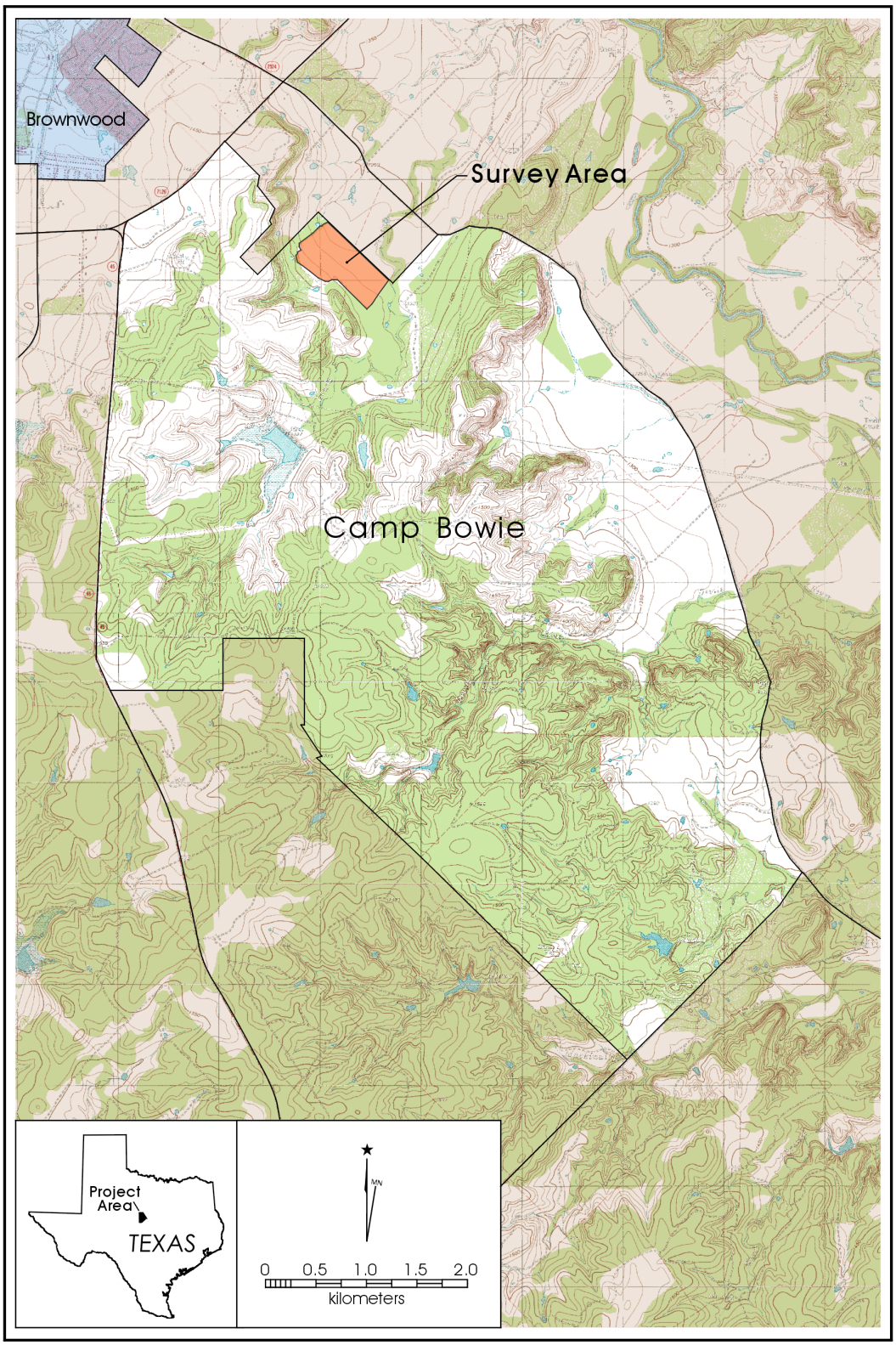

Figure 4. The project area within Camp Bowie.
A biological inventory of Camp Bowie, prepared by the Texas Parks and Wildlife Department (TPWD 1994), provides an extended discussion of plants and animals observed, or expected to be present, at Camp Bowie. The extant plant communities appear to have been altered by a variety of land uses, including attempts to increase grass cover for livestock. Much of the area can be characterized as a Live Oak, Mesquite, Ashe Juniper community. Major tree and shrub species present include a variety of oaks, ashe juniper, mesquite, pecan, cedar elm, American elm, lotebush, and whitebush. Grasses, including Texas grama and buffalo grass, and a variety of cacti are also present. Major mammalian fauna include whitetailed deer, jackrabbit, and cottontail (Adjutant General's Department of Texas 1992; Nature Conservancy of Texas 1996; TPWD 1994).

\section{The Survey Area}

The survey area consists of approximately 90 acres (ca. 38 ha.) that was under cultivation during the original Camp Bowie survey conducted by Wormser and Sullo-Prewitt (2001). Figure 4 identifies the survey area within Camp Bowie. The survey area is a roughly rectangular shaped block, measuring approximately $900 \mathrm{~m}$ by $425 \mathrm{~m}$. The relatively flat survey parcel ranges in elevation from 1,400 feet (427 m) ASL on the southwestern side to just below 1,370 feet (418 m) ASL on the north. At the time of the survey ground visibility was good, with the primary vegetation consisting of small mesquite bushes and short grass (Figure 5). As noted above, the survey tract had been plowed, and a series of berms are clearly present on the ground. Figure 6, an aerial photo of the survey area taken in 1995, shows these berms. 


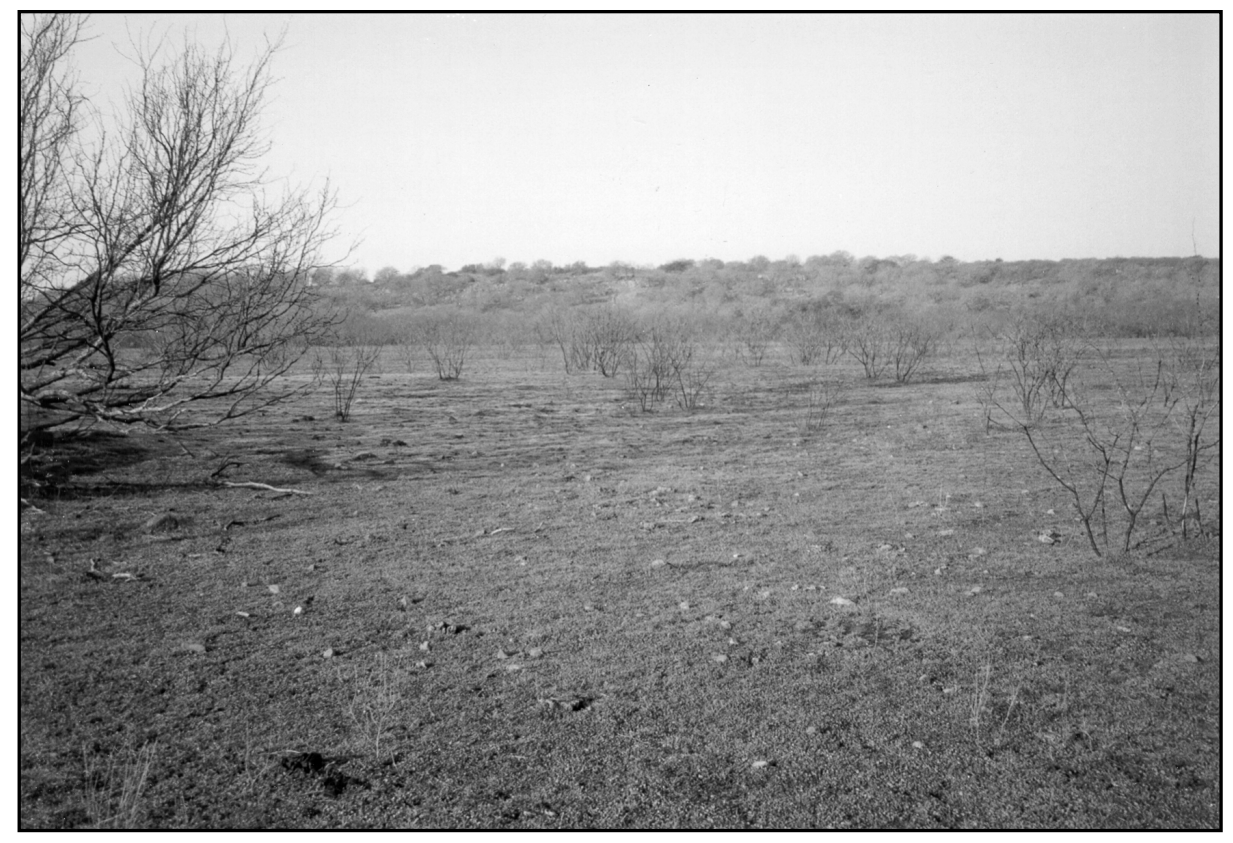

Figure 5. Photo of the survey area.

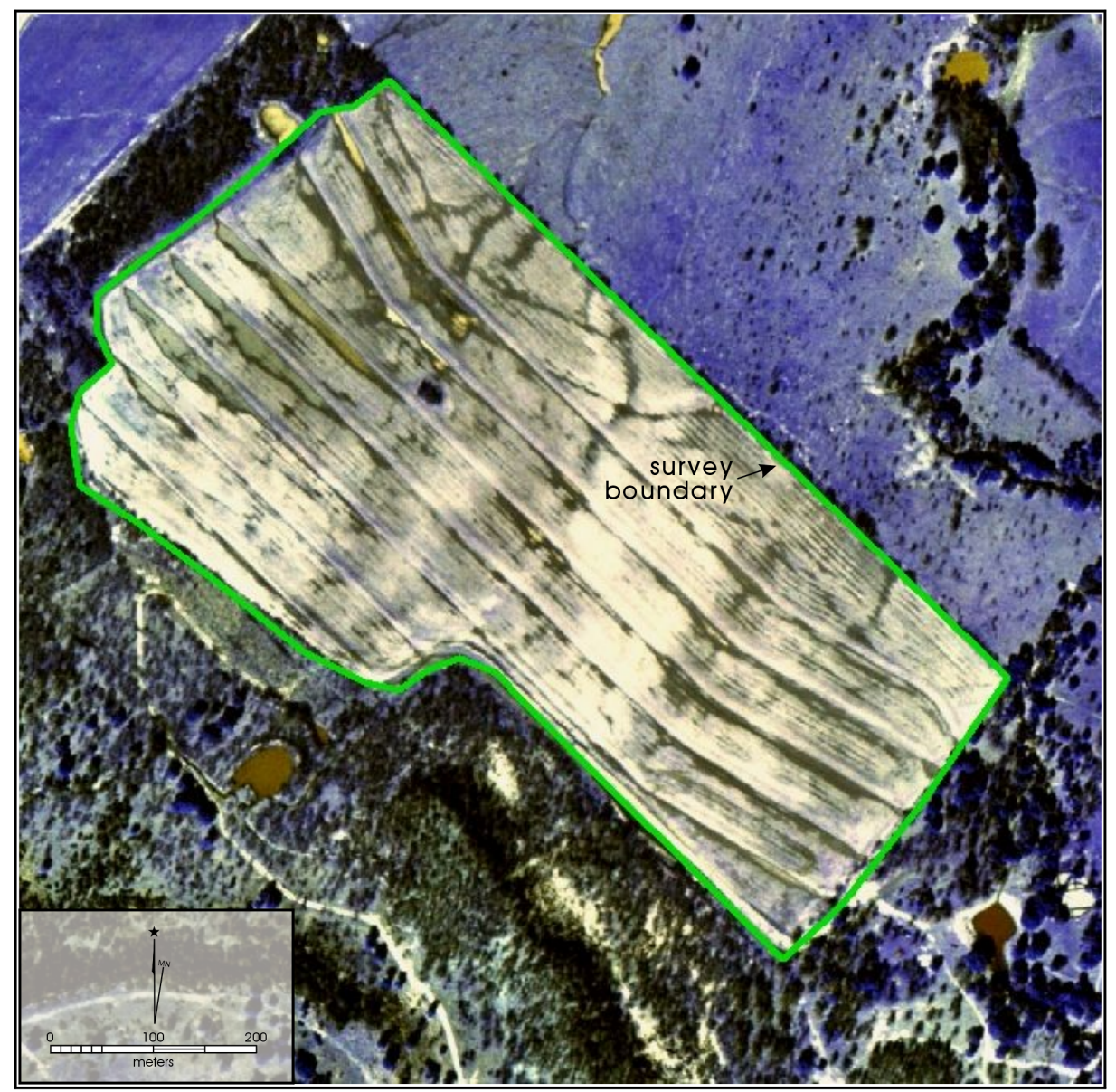

Figure 6. Aerial photo of the project area. 


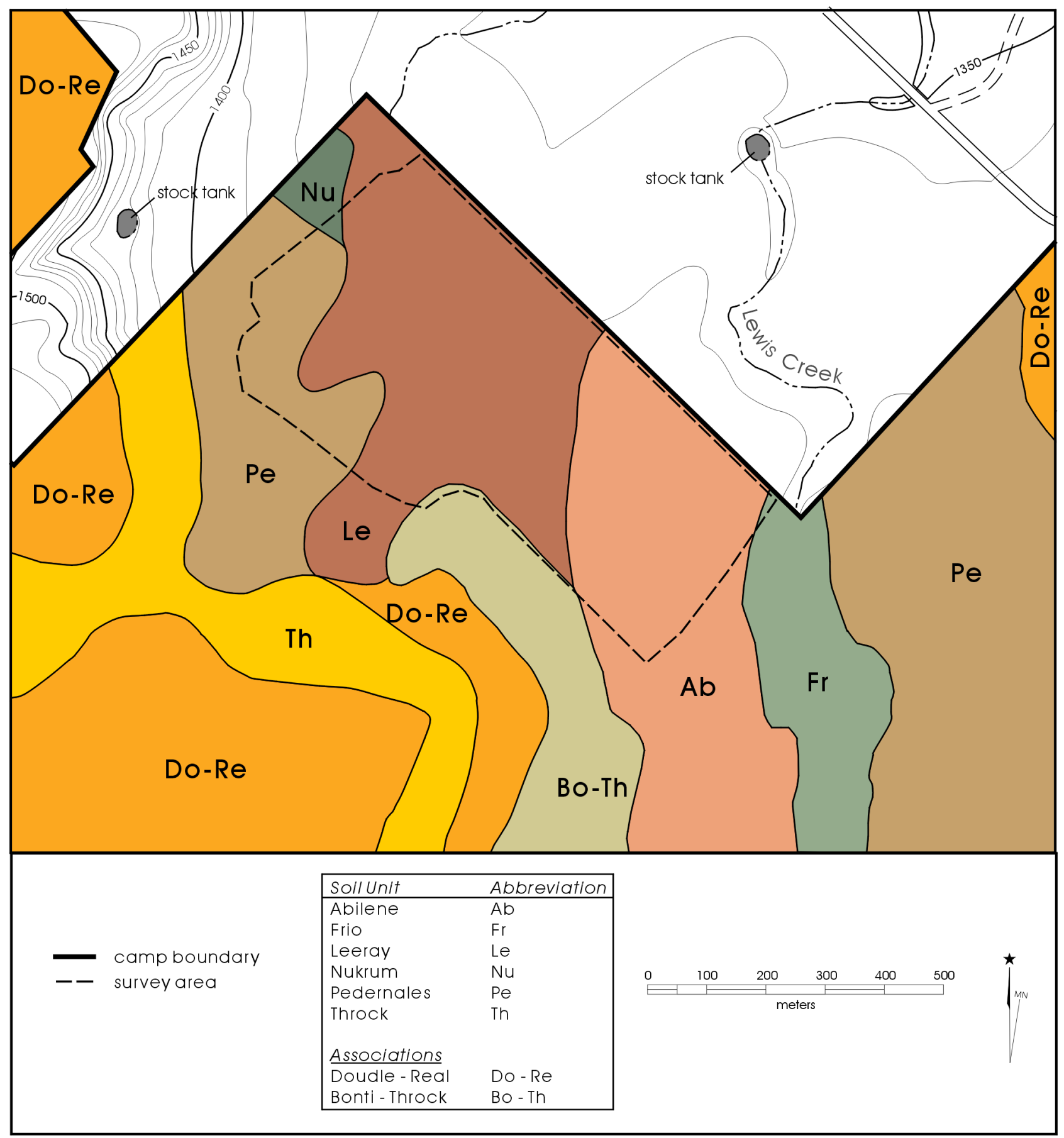

Figure 7. Soils within the project area.

Figure 7 presents a grouping of soils within the project area. From roughly east to west, soil units found within the project area are Frio, Abilene, Leeray, BontiThrock, Nukrum, and Pedernales. Abilene and Leeray soils, which have low potential for buried cultural deposits according to Wormser and Sullo-Prewitt
(2001), predominate. Bonti-Throck and Pedernales soils have low, and low to moderate probability for buried, potentially intact deposits, respectively. Soils with moderate to high probability, Frio and Nukrum, minimally intrude into the project area (Wormser and Sullo-Prewitt 2001). 


\section{Chapter 3: Prehistoric Cultural Background and Previous Research at Camp Bowie}

This chapter provides an overview of the archaeological record for the Brown County area, along with a summary of previous archaeological research conducted at Camp Bowie. While a brief summary is provided of all prehistoric periods, the focus of the cultural background is on the Archaic and Late Prehistoric periods, the two time frames represented by archaeological material recovered on the current project. No historic material was recovered on the current project. A detailed summary of the Historic period on Camp Bowie can be found in Wormser and Sullo-Prewitt (2001).

The Brown County/Camp Bowie area lies in the northwest corner of the Central Texas archaeological region (Collins 1995; Turner and Hester 1993). The major cultural periods defined for this region are briefly described below. Additional information can be found in Collins (1995) and Johnson and Goode (1994).

\section{Paleoindian}

The Paleoindian period marks the first appearance of humans in the New World, although the exact date for their arrival is unclear. Traditionally, the Paleoindian period is first marked by the appearance of Clovis points, which in turn are followed by Folsom points. The later Paleoindian period (10,000-8000 B.P.) is characterized by a variety of dart points, including Plainview, Dalton, Angostura, Scottsbluff, and Golondrina (Black 1989a, 1989b). Despite changes in these various projectile point types through time, their geographic range is widespread.

Paleoindian artifacts, particularly projectile points, are often recovered only as isolated finds, though camp, lithic procurement, kill, cache, ritual, and burial sites are known (Collins 1995). Early Paleoindian peoples have generally been conceptualized as hunter-gatherers ranging over wide areas in pursuit of now extinct megafauna, such as mammoths and Bison antiquus. This view of Paleoindian peoples, much like the dating of this period, is now being reassessed. While certainly exploiting Late Pleistocene megafauna, these peoples are perhaps better characterized as more generalized hunter-gatherers. By the later Paleoindian time frame, after the extinction of these megafauna, the hunting aspect of subsistence shifted to exploitation of large herbivores such as deer and Bison bison.

\section{Archaic}

The Archaic period can be broadly defined by changes in projectile point types, an increase in the number and types of sites (including burned rock hearths and middens), and by an increase in the variety of artifact styles, with many artifacts having more limited geographical distribution. While a number of finer subdivisions exist for the Archaic (e.g., Prewitt 1981; Weir 1976), this period can be broadly divided into the Early, Middle and Late Archaic.

\section{Early Archaic}

Collins (1995:383) dates the Early Archaic from 8800 to 6000 B.P. in Central Texas, with three divisions based on projectile point types. Hester (1995:436-438) identifies the Early Archaic with Early Corner Notched and Early Basal Notched dart points roughly dating between 7950 to 4450 B.P. On the Southern Great Plains the Early Archaic is approximated at 8000-5000 B.P. (Hofman 1989), although Johnson and Holliday (1986) offer more fine-grained dates of 8500-6400 B.P. for the Llano Estacado, based on data from the Lubbock Lake site. The extinction of large herds of megafauna and the changing climate at the beginning of the Holocene appears to have stimulated a behavioral change by the prehistoric inhabitants of Texas. While basic hunter-gatherer adaptations probably remained intact, an economic shift away from big game hunting was necessary. In general, more intensive exploitation of local resources in central Texas, such as deer, fish, and plant bulbs, is indicated by greater densities of ground stone artifacts, fire-cracked rock 
cooking features, and more specialized tools such as Clear Fork gouges and Guadalupe bifaces (Turner and Hester 1993:246, 256). Weir (1976) speculates that Early Archaic groups were small and highly mobile, an inference based on the fact that Early Archaic sites are thinly distributed and that diagnostic projectile point types are seen across a wide area, including most of Texas and northern Mexico. Hurt (1980) suggests that the decline in the number of bison on the plains forced the inhabitants to broaden their diets to include plants and animals that would produce the same amount of calories and protein with the same or slightly more effort expended. Story (1985) also suggests that population densities were low during this period, and that groups consisted of related individuals in small bands with "few constraints on their mobility" (Story 1985:39). Their economy was based on diffuse utilization of a wide range of resources, especially such year-round resources as prickly pear and lechugilla, as well as rodents, rabbits, and deer (Story 1985:38).

\section{Middle Archaic}

Collins (1995:383) defines this intermediate interval of the Archaic as lasting from about 6000-4000 B.P. in Central Texas, while Hester (1995:438-441) suggests that the period between 4450-2350 B.P. more correctly reflects the Middle Archaic in South Texas. The Southern Plains Middle Archaic complex as derived from changes in climate and subsistence, is recognized generally as the period between $5000-3000$ B.P. (Hofman 1989:45-47), and more specifically as 6400-4500 в.P. on the Llano Estacado (Johnson and Holliday 1986:46). The Middle Archaic appears to have been a time of increasing population densities, based on the large number of sites from this period in South and Central Texas (Story 1985:40; Weir 1976:125, 128). The reasons for this increase are not known, but the amelioration of a very dry period (Altithermal) during the Early Archaic is often seen as the prime mover (Story 1985:40). A wide variation in projectile point styles at the Jonas Terrace site suggests "a time of ethnic and cultural variety, as well as group movement and immigration" (Johnson 1995:285). Hurt (1980) posits that the quantity of diversified game animals on the Southern Great Plains decreased, and thus led to an intensified, less broad diet. On the South
Texas Plains, exploitation of widely scattered, yearround resources such as prickly pear continued (Campbell and Campbell 1981:13-15), as did hunting deer and rabbit. However, a shift to concentrated, seasonal nut harvests in the riverine environments of the Balcones Escarpment seems to have occurred (Black 1989a; 1989b). Weir (1976) believes that an expansion of oak on the Edwards Plateau and Balcones Escarpment led to intensive plant gathering and acorn processing. He also believes that the widely scattered bands prevalent in the Early Archaic now began to coalesce, at least during the acorn-gathering season, into larger groups who shared the intensive work of gathering and processing the acorn harvest (Weir 1976:126). Many researchers believe burned rock middens are a result of this endeavor (Creel 1986; Prewitt 1991; Weir 1976). Other investigators doubt this conclusion (Black et al. 1997; Goode 1991), but the exact processes that formed the burned rock middens are still a matter of controversy (see Hester 1991; Leach and Bousman 2001).

The common presence of deer remains in some burned rock middens encourages the view that deer processing took place at burned rock midden sites (Black and McGraw 1985:278; Nickels et al. 2001; Weir 1976:125). Bison bone is encountered in archaeological sites in Central and South Texas, at least occasionally, during all but the earliest part of the Middle Archaic (Dillehay 1974). There has been a tendency to equate presence of burned rock middens with absence of bison (Prewitt 1981); however, examinations of several recent faunal reports show that after about 4500 B.P. bison and burned rock middens are contemporaneous, though not at the same sites, at least in the southern Edwards Plateau and northern South Texas Plains (Meissner 1993).

\section{Late Archaic}

Collins (1995:384) dates the final interval of the Archaic in Central Texas to approximately 4000-800 B.P. Hester believes the Late Archaic in South Texas may better be defined as between 2350-1250 B.P., while Hofman's (1989:45) synthesis of these data places the Late Archaic on the Southern Plains as 3000-2000 B.P., and possibly later. Johnson and Holliday (1986:46) 
specify 4500-2000 B.P. as the Late Archaic period on the Llano Estacado. Some researchers believe populations increased throughout the Late Archaic (Prewitt 1985), while others feel populations remained the same or fell during this period (Black 1989a). Prewitt (1981:80-81) asserts that the accumulation of burned rock middens nearly ceased during the course of this period; however, excavations at a number of sites (e.g., Houk and Lohse 1993:193-248; Johnson 1995) provide evidence that large cooking features up to $15 \mathrm{~m}$ in diameter were still very much in use. Subsistence is assumed to have become less specialized (Black 1989a:30). Hurt (1980) asserts that bison began returning to the Southern Great Plains area, and we see an increase in intensive processing of bison, as well as mussel shells during the Late Archaic. However, by about 1450 B.P., bison had again disappeared (Dillehay 1974).

A proliferation of distinguishable human cemeteries has been attributed to this period, with the earliest occurrences dating to the South Texas Middle Archaic (Hester 1995:439-440). At Loma Sandia, these date between ca. 2550 and 2750 B.P. (Taylor and Highley 1995). Story (1985:44-45) believes the presence of cemeteries at sites such as Ernest Witte (Hall 1981), Hitzfelder Cave (Givens 1968), and Olmos Dam (Lukowski 1988) indicates that Late Archaic populations in Central and South Texas were increasing and becoming more territorial.

Although inhabitants of the South Texas Plains near Brownsville and Rockport had begun to make pottery by about 1750 B.P., the northern part of the plain was still "pre-ceramic" until 1,000 years later (Story 1985:45-47). Late Archaic points tend to be much smaller than Middle Archaic points. The most common are Ensor and Frio types both of which are short, triangular points with side notches (Turner and Hester 1993:114, 122). The Frio point also has a notched base (Turner and Hester 1993:122).

A late subperiod or interval of the Late Archaic is frequently referred to as the Terminal Archaic or Transitional Archaic. Weir (1976) defines the Terminal Archaic as 1650-1150 B.P., while Turner and Hester (1993) cite data placing the Transitional Archaic as 2250-1250 в.P. Although Hester may lump current data into a Late Archaic period, he cautions that more evidence will likely result in what may be termed as a "Terminal Archaic" period during the latter part of the Late Archaic in South Texas. This Terminal Archaic period is represented by diagnostics such as Ensor, Frio, and Matamoras points which appear to overlap the Late Archaic and Late Prehistoric periods (Hester 1995:442). Weir (1976) believes this marked a transition period to localized area sites, a disappearance of burned rock middens and bison, and a reappearance of highly mobile hunters and gatherers. Others (Black and McGraw 1985; Skelton 1977) argue that in some locations burned rock middens did not disappear and sites were more intensely occupied during the Transitional Archaic period. During the Early Neo-Indian period on the Southern Great Plains (ca. 950-1450 в.P.), Hurt (1980) presents evidence for a decrease in bison processing. This decrease is consistent with Dillehay's (1974) contention that there were fewer bison available in the area during this time period due to climatic changes.

\section{Late Prehistoric}

The term Late Prehistoric is commonly used to designate the period following the Late Archaic in Central and South Texas. Collins (1995:385) recognizes that the commonly used date of 1200 B.P. for the end of the Archaic and beginning of the Late Prehistoric in Central Texas is arbitrary, and Hester (1995:442) acknowledges the problematic issue of selected tools appearing at both Late Archaic and Late Prehistoric sites. A series of distinctive traits mark the shift from the Archaic to the Late Prehistoric period, including the technological shift to the bow and arrow and the introduction of pottery to Central Texas and the northern portion of the South Texas Plains (Black 1989a:32; Story 1985:45-47). Two complexes following the Late Archaic in the Southern Great Plains region are the Plains Woodland from about 2000-1150 B.P., and the Plains Village from 1150-450 B.P. (Hofman 1989:6190). Most researchers agree the early Late Prehistoric period was a time of population decrease (Black 1989a:32). Though small burned rock middens associated with Scallorn and Edwards points have been found (Goode 1991:71; Houk and Lohse 1993:193-248), most researchers argue that they are 
rare. Settlement shifts into rockshelters such as Scorpion Cave in Medina County (Highley et al. 1978) and Classen Rockshelter in northern Bexar County (Fox and Fox 1967) have been noted (Skinner 1981). Cemeteries from this period often reveal evidence of conflict (Black 1989a:32).

Beginning rather abruptly at about 650 B.P., a shift in technology occurred. This shift is characterized by the introduction of blade technology, the first ceramics in Central Texas (bone-tempered plainwares), the appearance of Perdiz arrow points, and alternately beveled bifaces (Black 1989a:32; Huebner 1991:346). Prewitt (1985) suggests this technology encroached from North Central Texas. Patterson (1988), however, notes the Perdiz point was first seen in Southeast Texas by about 1350 B.P., and was introduced to the west some 600-700 years later. Hester (1995:444) recognizes this phase as the "best documented Late Prehistoric pattern" throughout South Texas, with dates ranging between ca. $650 / 700$ to $300 / 350$ B.P.

Steele and Assad Hunter (1986) argue for the occurrence of a distinct change in diet between the Late Archaic and the Late Prehistoric components in two sites in the Choke Canyon Reservoir area of South Texas. Analysis of the number of identified specimens (NISP) shows a marked increase in artiodactyl elements during the late Late Prehistoric, an increase largely due to the addition of bison to the "menu" (Steele and Assad Hunter 1986:468). Huebner (1991) suggests that the sudden return of bison to South and Central Texas resulted from a more xeric climate in the plains north of Texas, and increased grass in the Cross-Timbers and Post Oak Savannah in north-central Texas, forming a "bison corridor" into the South Texas Plains along the eastern edge of the Edwards Plateau (Huebner 1991:354-355). Sites from this period frequently have associated bison (Black 1986; Black and McGraw 1985; Prewitt 1974).

\section{Previous Research in the Camp Bowie Area}

A review of archaeological literature for the Camp Bowie area produced limited results. Only a handful of excavation projects have been conducted, and with the exception of the recent survey of Camp Bowie
(Wormser and Sullo-Prewitt 2001), few small surveys have been carried out. Archaeological research in Brown County dates to the early portion of this century with the excavations by Pearce at the burned rock midden site of Pitman (41BR3) conducted in 1919 (Campbell 1952; Kirby and Moir 1976). Pearce trenched two middens, both of which appeared to have been ring or crescent shaped. While both contained large quantities of charcoal and fire-cracked limestone and a few fragments of bone and shell, no artifacts were recovered from either midden (Campbell 1952).

From the early work of Pearce in 1919 until the 1970s, no substantial archaeological investigations seem to have occurred in Brown County. Beginning in the early 1970 s, a series of survey projects were conducted, including two by archaeologists from Texas A\&M University (Shafer et al. 1975a, 1975b), a survey of Cordell and Camp Bowie City Park sites in Brownwood completed by Kegley and Black (1978), a survey by Southern Methodist University along Pecan Bayou north of Brownwood (Kirby and Moir 1976), and a survey by Prewitt and Associates for the City of Brownwood sanitary landfill site (Prikryl 1983). All of these surveys consistently recorded lithic scatters and burned rock features, including the presence of large ring and dome shaped middens.

In 1979, the Texas Archeological Society field school was located near Cross Cut in the far northwest corner of Brown County. Gearhart and Voellinger (1986) report that work was conducted on both ring and mound shaped burned rock middens. In addition, Howard (1991) references excavations of three burned rock midden sites in Brown County (41BR72, 41BR105, and 41BR110). However, additional information on these projects could not be located.

In 1986, Espey, Huston \& Associates conducted testing at 41BR313 and 41BR314 (Gearhart and Voellinger 1986), two sites originally documented by Prikryl (1983) during the sanitary landfill survey mentioned previously. A total of four 1 x 1-m units were excavated at these two sites. Testing did not reveal stratified deposits, and no additional work was conducted.

Prior to the 1993-1998 inventory survey of Camp Bowie (Wormser and Sullo-Prewitt 2001), little systematic work had been conducted on the installation. 
A tract of land within the Brownwood Laterals Watershed survey, conducted by Texas A\&M University in 1975 (Shafer et al. 1975b), was acquired by Texas Army National Guard. Three sites (41BR65, 41BR66, and 41BR68) were incorporated into Camp Bowie as a result of that acquisition. In addition, Wormser and Sullo-Prewitt (2001) reference smallscale survey work on the camp conducted by Briggs (1992), as well as two AGTX staff reports (Wormser et al. 1994, 1997).

AGTX archaeologists conducted an inventory survey of Camp Bowie between 1993-1998 (Wormser and Sullo-Prewitt 2001). A total of 186 prehistoric and historic sites were recorded. A variety of prehistoric site types were identified, including open campsites, lithic workshops, lithic procurement sites, and burned rock midden sites. The 90 -acre project area discussed in this report was under cultivation at the time and was not surveyed.

Figure 8 (not included in the text - see Report Organization in Chapter 1) presents the survey area, along with the location of all shovel tests, the three newly identified sites, and sites surrounding the current project area. A total of 10 sites, all of which were identified by Wormser and Sullo-Prewitt (2001), are within $500 \mathrm{~m}$ of the current survey area. Two of these sites (41BR423 and 41BR494) are historic, two (41BR462 and 41BR475) are Late Archaic, and the remaining six (41BR420, 41BR463, 41BR465, 41BR474, 41BR476, and 41BR492) are classified as temporally unknown. Two of the eight prehistoric sites have burned rock middens (41BR420 and 41BR492). Wormser and Sullo-Prewitt (2001) classify the remaining prehistoric sites as open campsites. 


\section{Chapter 4: Survey and Laboratory Methodology}

As noted in the introduction, the Specification of Services and Scope of Work produced by the Adjutant General's Department of Texas calls for the cultural resource inventory survey of approximately 90 acres (ca. $364,060 \mathrm{~m}^{2}$ ) of previously unsurveyed land. The survey area has been disturbed by activities associated with cultivation, though surface visibility was good with up to 80 percent of the ground surface visible.

The 90 -acre project area is bounded on all sides by well-defined landmarks. The northeast boundary is a fence line paralleled by a grass-covered dirt road just inside the project area. The southeast and southwest boundaries are marked by a grass-covered, continuous dirt road. On the southeast side, just beyond the road, is a seasonal creek. Beyond the road on the southern part of the southwest boundary is a large berm and channel that drains into the above-mentioned creek. Beyond the road on the northern part of the southwest boundary is a tree line. A tree line also forms the northwest boundary of the project.

As noted previously, a number of berms cross the field, running northwest to southeast, roughly parallel to the long axis of the field. These berms provide evidence for the former cultivation of this area. Plowing has resulted in extensive disturbance of the upper portion of the field, and the presence of many pieces of sandstone on the ground surface. In a small number of cases, this sandstone may be burned, but given the amount of material and the ubiquity of the distribution, it was not recorded as cultural. Also present in the area are several cases of burns, probably associated with clearing of mesquite. Piles of mesquite are present, and in several instances it appears that charcoal encountered in the upper levels of shovel tests may be the result of modern burning of these piles. Currently, the area is leased out for cattle grazing. Military activities associated with this field before its use as agricultural land are largely unknown. However, a large number of bullet slugs with no casings, particularly concentrated on the southwestern portion of the field, may suggest at least part of it was used as a firing range.

\section{Survey Methods}

Consistent with the Specification of Services, CAR personnel, in February, March, and May of 2001, conducted a pedestrian survey. Transects were spaced at $30-\mathrm{m}$ intervals and were oriented perpendicular to a northwest to southeast running fence line that demarcated the northeast boundary of the project area. A total of 27 transects spanned the field. Shovel tests were spaced at 60-m intervals on selected transects. Shovel tests were defined as $30-\mathrm{cm}$ diameter units. The shovel tests were excavated in 10-cm levels. Deposits from these tests were screened through $1 / 4$-inch mesh screens, all artifacts were collected, and observations on the shovel tests were recorded on standardized forms. All shovel test locations were recorded using a Trimble GeoExplorer II Global Positioning System (GPS) unit. A total of 104 shovel tests were excavated on transects, with the number of shovel tests per transect ranging from 5 to 8 (Figure 9). Shovel tests were always excavated to $50 \mathrm{~cm}$ below surface ( $\mathrm{cm} \mathrm{bs}$ ), and in selected cases, tests were taken to $70 \mathrm{~cm}$ bs.

For the purpose of this survey, sites were defined as locations having at least five artifacts within a $30 \mathrm{~m}^{2}$ area or as a location containing a single cultural feature such as a hearth. All other artifacts were classified as isolated occurrences, though no such occurrences were present on the current survey. When an artifact concentration was identified as a site, crew members established a datum, consisting of a length of rebar hammered into the ground at the site's center. Using GPS units, CAR surveyors took readings from the datum of the site and from enough points along the perimeter to define the estimated site boundary. A standardized form containing observations concerning site disturbance, vegetation, estimated artifact counts by category, and observations on features were completed. Diagnostic artifacts were collected when found, and their location recorded with a GPS unit. In addition, sketch maps, showing site boundaries, datum locations, shovel tests, collected items, features, areas of high artifact density, and physical features on the landscape, were recorded. Archival quality 35-mm 
black-and-white prints were made of all sites and artifacts where appropriate. Texas site forms were prepared for all new sites encountered on the project.

As noted previously, three sites were recorded on the current project. Additional shovel tests were excavated within or around these site boundaries to clarify the nature and extent of subsurface deposits. A total of 12 additional shovel tests were excavated. The excavation of these shovel tests followed the procedure outlined previously for the transects.

In the majority of shovel tests, CAR archaeologists collected soil samples from all levels. These samples were subsequently analyzed for magnetic susceptibility. Several authors have demonstrated that the potential for magnetization of a sediment can be enhanced by the addition of organic material, including charcoal and ash that would commonly be associated with archaeological sediments (see Gose and Nickels 2001; McClean and Kean 1993; Singer and Fine 1989). Sediments with higher organic content tend to have higher magnetic susceptibility values, probably as a result of the production of maghemite, an iron oxide, during organic decay (Reynolds and King 1995). The magnetic susceptibility samples were analyzed at CAR, and a complete discussion of the results is presented in Appendix A.

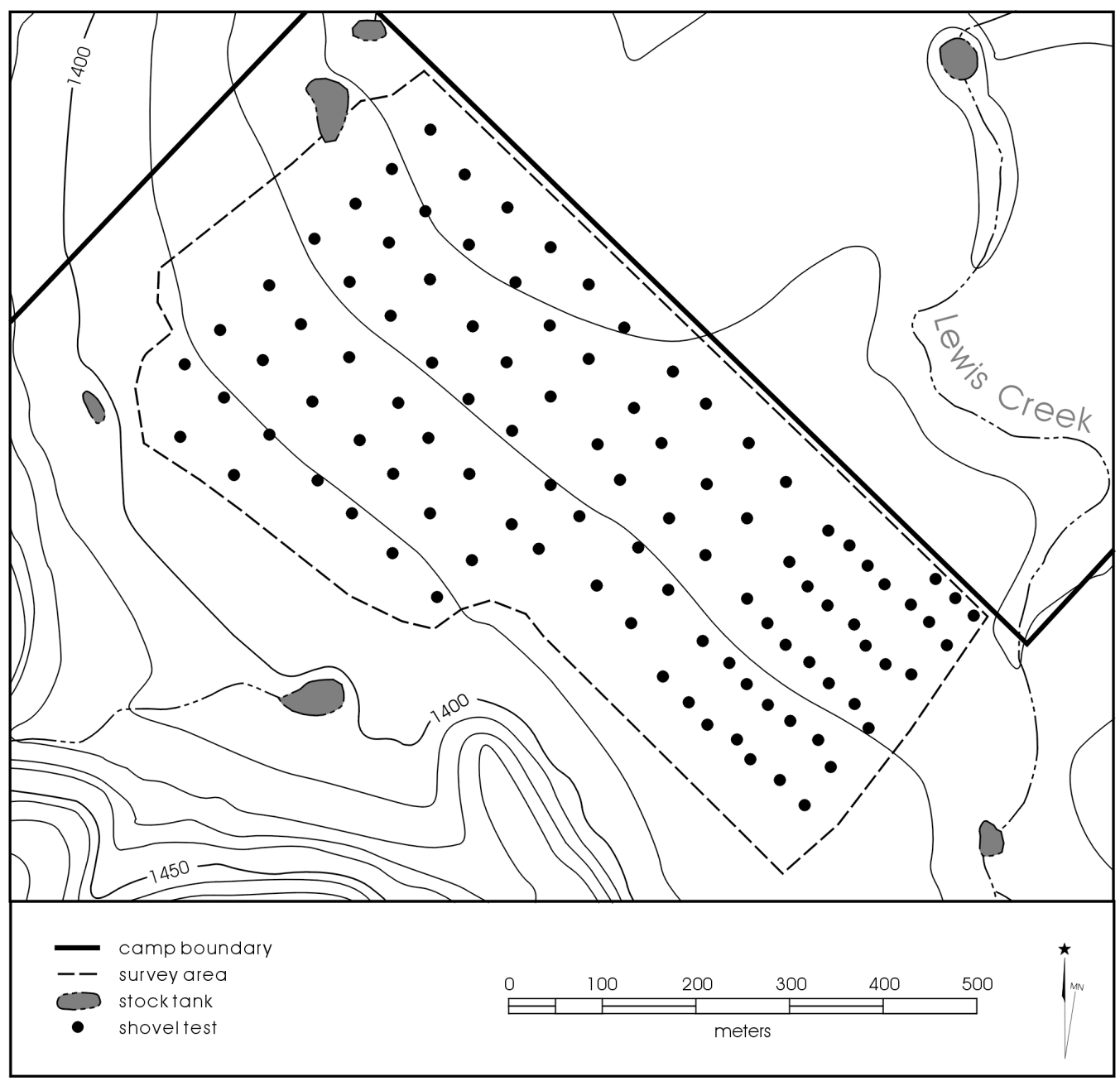

Figure 9. Survey area with shovel tests. 


\section{Laboratory Methods}

All cultural material collected during the survey was prepared in accordance with federal regulation 36 CFR, part 79, and in accordance with current guidelines of the Texas Archeological Research Laboratory (TARL). Artifacts processed in the CAR laboratory were washed, air-dried, sorted into appropriate categories (e.g., debitage, projectile points, bifaces, unifaces, cores), analyzed, and stored in archival-quality bags. Acid-free labels were placed in all artifact bags. Each label contained a provenience or corresponding lot number. Tools were labeled with permanent ink and covered by a clear coat of acrylic. In addition, a small sample of unmodified debitage from each lot was labeled with the appropriate provenience data. All artifacts were stored in acid-free boxes. Boxes were labeled with standard labels. Field notes, forms, photographs, and drawings were placed in labeled notebooks. Photographs, slides, and negatives were placed in archival-quality sleeves. All materials were stored in acid-free boxes. Documents and forms were printed on acid-free paper. Upon completion of the project, all cultural materials and records will be sent to the Texas Archeological Research Laboratory for permanent storage. 


\section{Chapter 5: Survey Results}

This chapter summarizes the survey and shovel testing results, including discussions of the soil susceptibility results and descriptions of all sites recorded within the survey area. The survey and shovel testing revealed three prehistoric sites in the project area (see Figure 8).

\section{Systematic Shovel Test Results}

As noted previously, a total of 104 shovel tests were systematically excavated across the survey area. The survey consisted of 27 transects, numbered from southeast to northwest, and shovel test rows were numbered from 1 to 9 . Within the plowed field, sediments were consistent throughout the shovel tests, consisting of a hard to compact, blocky, dark brown to gray clay or silty clay. Inclusions were not common, but when present consisted of small amounts of gravels and pebbles. Only in the southwestern portion of the field, in areas of transects 17-27, shovel test rows 5-9, did this pattern change. Here, the upper $20 \mathrm{~cm}$ of sediment frequently consisted of sandy clay. Below $20 \mathrm{~cm}$, these deposits were similar to those noted elsewhere. In addition to the 104 transect shovel tests, 12 shovel tests were placed within sites 41BR499, 41BR500, and 41BR501. In all cases where these shovel tests were placed within the plowed field, the sediments were the same as those described above.
Overall, a surprisingly low frequency of artifacts were recovered from these shovel tests. Only six shovel tests were positive, and only 12 artifacts were recovered. All positive shovel tests were within sites. Data for these positive shovel tests are summarized in Table 1.

\section{Soil Susceptibility Results}

As noted in the previous chapter, in the majority of shovel tests, CAR collected soil samples from all levels that were subsequently analyzed for magnetic susceptibility. A total of 513 samples from 101 transect shovel tests were analyzed for susceptibility. This total was supplemented by an additional 60 samples collected from the 12 shovel tests placed specifically within site boundaries. Appendix A presents detailed information regarding the samples, laboratory procedures, and individual results.

Table 2 presents summary data, by level, for the 101 transect shovel tests for levels one through five. The values reflect the corrected magnetic soil susceptibility values. Included in the table are the mean values for a level, the standard deviation, the minimum and maximum values for a level, and the median value. Considering the summaries of central tendencies (i.e., mean and median values), it is clear that levels two and three have slightly higher overall values,

Table 1. Artifacts Recovered from Shovel Tests

\begin{tabular}{|c|c|c|c|l|}
\hline Transect & Shovel Test & Depth & Site & \multicolumn{1}{|c|}{ Recovery } \\
\hline 3 & 2 & 10 to $20 \mathrm{~cm}$ & $41 \mathrm{BR} 499$ & 1 chert tertiary flake \\
\hline na & 7 & 0 to $10 \mathrm{~cm}$ & $41 \mathrm{BR} 500$ & 3 chert tertiary flakes \\
\hline na & 7 & 10 to $20 \mathrm{~cm}$ & $41 \mathrm{BR} 500$ & 1 chert secondary flake. 1 chert tertiary flake \\
\hline na & 7 & 20 to $30 \mathrm{~cm}$ & $41 \mathrm{BR} 500$ & 2 chert tertiary flakes \\
\hline 5 & 5 & 0 to $10 \mathrm{~cm}$ & $41 \mathrm{BR} 500$ & 1 chert tertiary flake \\
\hline na & 5 & 10 to $20 \mathrm{~cm}$ & $41 \mathrm{BR} 500$ & 1 chert tertiary flake \\
\hline 5 & 6 & 10 to $20 \mathrm{~cm}$ & $41 \mathrm{BR} 500$ & Broken Darl chert projectile point \\
\hline 11 & 5 & 40 to $50 \mathrm{~cm}$ & $41 \mathrm{BR} 501$ & 1 chert marginally retouched tool \\
\hline
\end{tabular}


Table 2. Soil Susceptibility Values from Transect Shovel Tests

\begin{tabular}{|c|c|c|c|c|c|c|}
\hline Level & No. of Samples & Mean & St. Dev. & Min. & Max. & Median \\
\hline 1 & 101 & 42.9 & 16.67 & 14.8 & 81.6 & 38.2 \\
\hline 2 & 101 & 44.1 & 17.94 & 10.6 & 86.3 & 40.7 \\
\hline 3 & 101 & 43.5 & 19.19 & 13.5 & 88.2 & 40.7 \\
\hline 4 & 101 & 41.4 & 19.88 & 11.2 & 86.2 & 37.9 \\
\hline 5 & 100 & 40.8 & 20.74 & 12.7 & 84.6 & 39.4 \\
\hline
\end{tabular}

suggesting that material with higher potential for magnetism are slightly greater in these levels. As noted in Appendix A, these higher scores could result from a variety of processes, including both a higher frequency of organic material as well as the presence of ash and charcoal possibly associated with human occupation. Note, however, that there is considerable variability in the scores as reflected both by the standard deviation values and the overall range.

Figure 10 presents the results of the magnetic susceptibility values for one of these higher levels, level three $(20-30 \mathrm{~cm})$, of the survey area. Darker reds denote areas of high magnetic susceptibility values, while

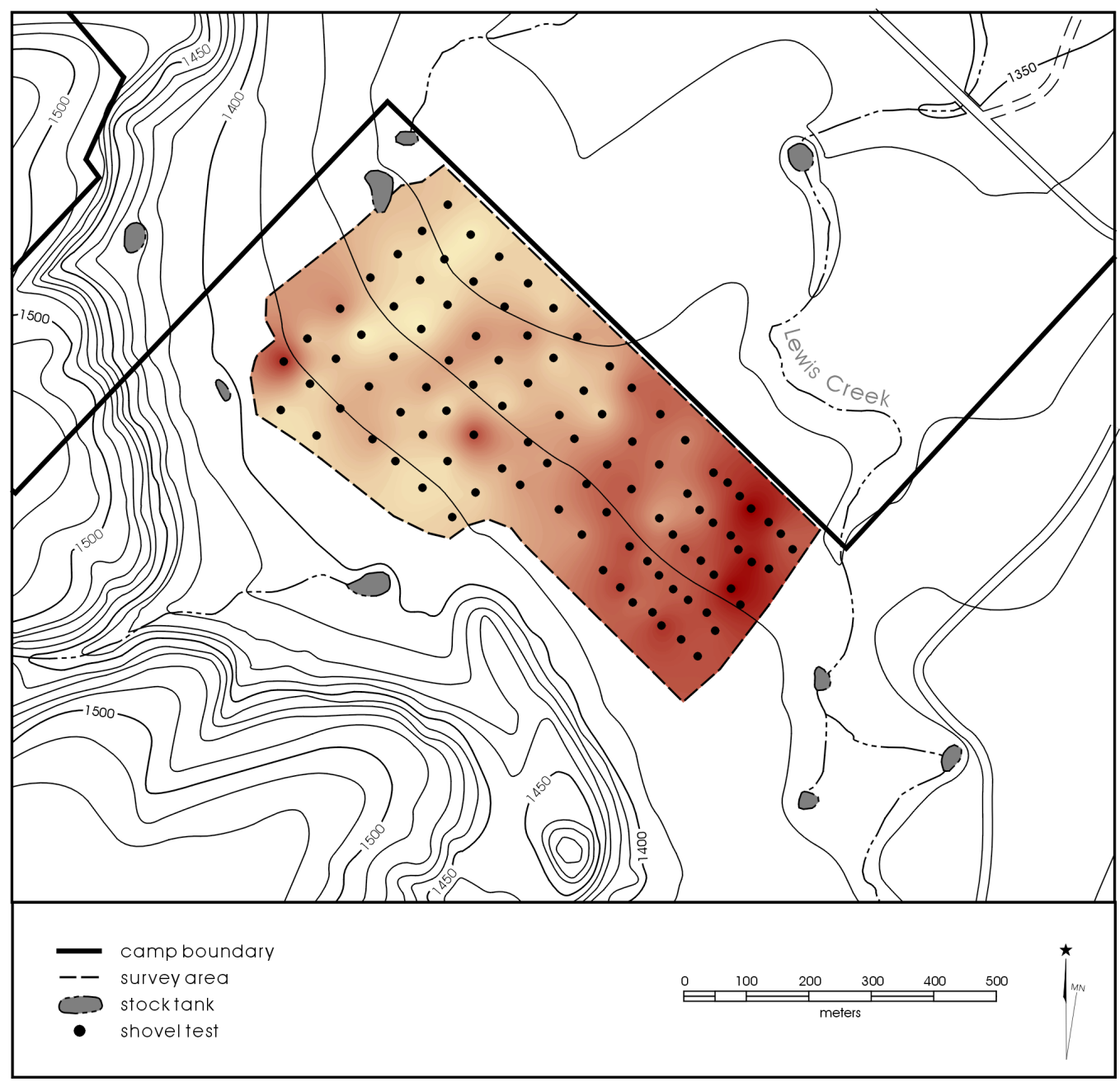

Figure 10. Soil susceptibility for Level 3. 
lighter color ranges denote lower values. With two exceptions, higher values are confined primarily to the southeastern portion of the survey area. This area, then, has consistently higher values, values that may be indicative of increased cultural activity within this zone. However, several different elements can contribute to higher values. One such potential impact can be seen by comparing Figure 10 with Figure 7, the distribution of soils within the project area, presented in Chapter 2. Such a comparison will suggest that higher values closely parallel the distribution of the Abilene soil unit.

Table 3 presents a comparison of the mean, minimum, and maximum values for the Abilene soils with those from the remaining portion of the project area. Clearly, the Abilene soil unit has significantly higher values, regardless of the level. This suggests that the differences reflected in Figure 10 are primarily related to differences in the magnetic potential of the parent material.

As discussed previously, in addition to the transect shovel tests, additional shovel tests were placed on sites. Using both the transect shovel tests that fell within site boundaries, as well as these additional shovel tests, a total of 22 shovel tests were placed within the three sites. All three sites fell primarily within the Abilene soils. Table 4 presents a comparison of mean, standard deviation, and the minimum and maximum values of those shovel tests that fell within site boundaries, as well as those shovel tests for the Abilene soils that were outside of the sites. Note that the mean values for the site and non-site contexts do not appear to be significantly different, though levels two and three within the site boundaries are slightly higher. Focusing on the standard deviation and the maximum scores for these two levels suggest that extremely high values are present for at least some of the shovel tests on site. Reference to data presented in Appendix A will demonstrate that these high values are the result of a single case, Shovel Test (ST) 7 on 41BR500.

Figure 11 presents the magnetic susceptibility values for this anomalous case on 41BR500 along with the range of values for the remaining samples from sites. Note the extremely high values for levels two and three. These values account for the higher overall scores in Table 4. These values are also consistent with the presence of a feature or buried surface at 10 to 30 $\mathrm{cm}$ below the surface. Reference to Table 1 will demonstrate that this shovel test also had cultural material between 0 and $30 \mathrm{~cm}$ below surface. Also noted were several occurrences of sandstone. The presence of sandstone, artifacts, and high soil susceptibility values clearly suggest that either a buried feature or surface is present at this location.

Table 3. Soil Susceptibility Values for Transects by Soil Units

\begin{tabular}{|c|cccc|cccc|}
\hline \multirow{2}{*}{ Level } & \multicolumn{4}{|c|}{ Ab Soils } & \multicolumn{4}{c|}{ Other Soils } \\
\cline { 2 - 9 } & $\mathbf{n}$ & mean & min. & $\mathbf{m a x}$ & $\mathbf{n}$ & mean & min. & $\mathbf{m a x}$. \\
\hline 1 & 43 & 59.4 & 42.2 & 81.6 & 58 & 30.8 & 14.8 & 62 \\
\hline 2 & 43 & 61.2 & 38.4 & 86.3 & 58 & 31.5 & 10.6 & 62.7 \\
\hline 3 & 43 & 61.4 & 36.3 & 88.2 & 58 & 30.3 & 13.5 & 75.9 \\
\hline 4 & 43 & 61 & 34.9 & 86.2 & 58 & 26.9 & 11.2 & 55.5 \\
\hline 5 & 43 & 60.6 & 34.5 & 84.6 & 57 & 25.9 & 12.7 & 65.3 \\
\hline
\end{tabular}

Table 4. Soil Susceptibility Values for Sites and Non-sites within the Ab Soil Unit

\begin{tabular}{|c|ccccc|ccccc|}
\hline \multirow{2}{*}{ Level } & \multicolumn{4}{|c|}{ Non-Site } & \multicolumn{4}{c|}{ Site } \\
\cline { 2 - 11 } & $\mathbf{N}$ & Mean & Sd & Min. & Max. & N & Mean & Sd & Min. & Max. \\
\hline 1 & 33 & 60.4 & 10.77 & 42.2 & 81.6 & 22 & 54.6 & 9.95 & 26.3 & 72.4 \\
\hline 2 & 33 & 61.6 & 10.83 & 38.4 & 86.3 & 22 & 66.6 & 31.7 & 37.4 & 201.4 \\
\hline 3 & 33 & 61.9 & 11.68 & 36.3 & 88.2 & 22 & 63.7 & 15 & 48.9 & 116.9 \\
\hline 4 & 33 & 61.6 & 12.14 & 34.9 & 86.2 & 22 & 59.7 & 11.3 & 34.8 & 80.8 \\
\hline 5 & 33 & 60.3 & 12.33 & 34.5 & 84.6 & 22 & 60.4 & 10.7 & 42.9 & 79.9 \\
\hline
\end{tabular}




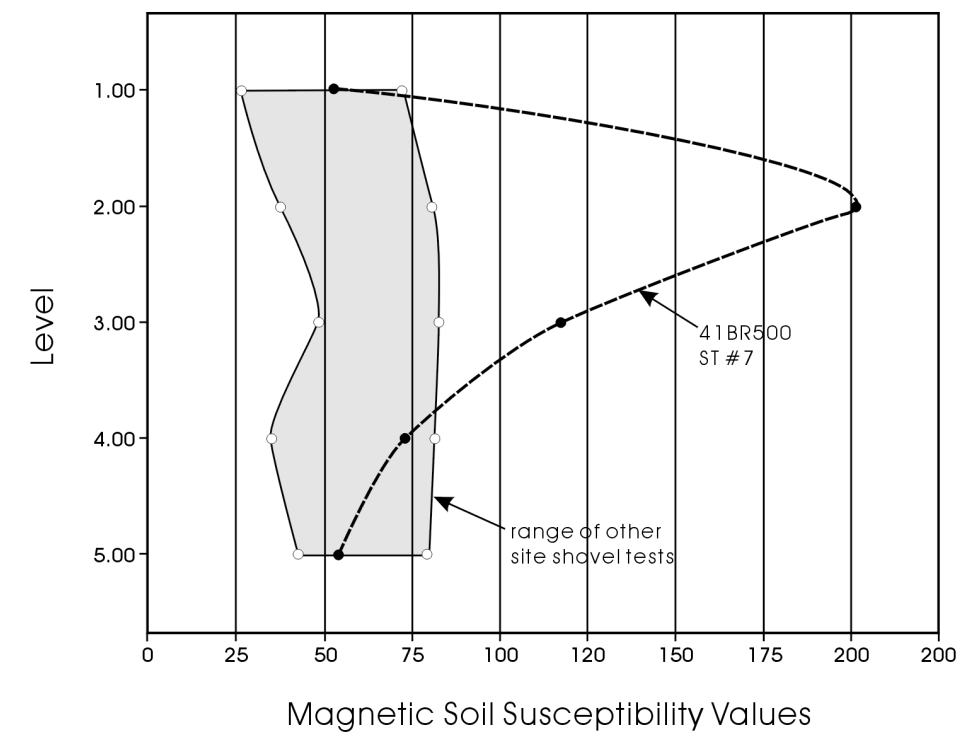

Figure 11. Comparison of soil susceptibility values for all sites with values for 41 BR500, ST-7.

\section{Site Descriptions}

Three archaeological sites were recorded on the current survey. Each of these is discussed separately. Maps showing site-specific locations (Figures 12, 14, and 17) are not presented in the text (see Report Organization in Chapter 1). Recommendations for these sites are presented in the following chapter.

\section{BR499}

41BR499 (Figure 12) is located close to the southeast corner of the project area. The site covers an area of approximately $3,850 \mathrm{~m}^{2}$. The site measures about 80 $\mathrm{m}$ north/south by $60 \mathrm{~m}$ east/west, and is located at an elevation of about 1,375 feet ASL. The site is on Abilene soils. These soils are described as having low probability in terms of potential for buried cultural deposits (Wormser and Sullo-Prewitt 2001). However, the site lies just north and west of a zone of Frio soils, which have a moderate to high potential for buried cultural deposits. Surface visibility ranged from 0 to 80 percent, depending on grass cover. Numerous small, young mesquite trees dot the site. Two berms cross the site and the dirt road that forms the project area's southeast boundary is also the southeast boundary of the site.

41BR499 is a small, surface lithic scatter consisting of at least two cores or tested cobbles, three bifaces, one retouched flake, and about 30 flakes (approximately 24 tertiary, five secondary, and one primary), and a single projectile point. No burned rock or features were identified, though angular chunks of sandstone are present on the surface. Only the projectile point, an untypeable arrow point fragment, was collected (Figure 13).

Three shovel tests excavated on the transects fell within the site boundary. These were Transect 1 , Shovel Test 2 (T1-ST2), Transect 2, Shovel Test 2 (T2-ST2), and Transect 3, Shovel Test 2 (T3ST2). Only in T3-ST2 were any artifacts recovered (Table 1). Subsequently, two additional shovel tests were excavated within the site, neither of which produced any artifacts.

\section{BR500}

41BR500 (Figure 14), located along the southwest boundary of the project area, covers an area of approximately $19,860 \mathrm{~m}^{2}$. The site measures about 315 $\mathrm{m}$ northwest/southeast by $120 \mathrm{~m}$ northeast/southwest, and is at an elevation of between 1,380 and 1,390 feet ASL. The southeastern 75 percent of the site lies on Abilene soils, while the remaining northwest portion lies on Bonti-Throck and Leeray soils. All three of these soil types are considered to have a low probability for buried cultural deposits (Wormser and Sullo-Prewitt 2001). Surface visibility was generally about 75 percent. A large berm, probably associated with an old road or channel, is present along the southwestern edge of the site. Numerous artifacts were present on this berm. The channel is approximately 
$7-12 \mathrm{~m}$ in width and about $1-1.5 \mathrm{~m}$ in depth. This channel runs the entire length of the site, and was filled with water at the time the site was recorded. Small mesquite trees covered the berm. Figure 15 provides two photos of the channel and berm, taken in May of 2001, when the water had receded.

41BR500 is a large lithic scatter. Artifacts observed on the surface included three bifaces, one uniface, one retouched flake, sandstone fragments (some of which are burned), over 100 tertiary flakes, over $100 \mathrm{sec}-$ ondary flakes, and 10 primary flakes. Many spent bullets were also observed. None of these artifacts were collected. A single quartzite mano, approximately 11.4 $\mathrm{cm} \times 7.6 \mathrm{~cm}$ in size with grinding on both faces and hammering on both ends, was collected (Figure 16). In addition, two projectile points, a Darl and a Pedernales (Figure 13), were collected from the surface of the western edge of the site, on the west side of the channel. Darl and Pedernales points both date to the Late Archaic (Collins 1995; Johnson and Goode 1994; Turner and Hester 1993), and suggest this temporal affiliation for the site.

\section{BR501}

41BR501 (Figure 17), located just southeast of the center of the project area, covers an area of approximately $12,190 \mathrm{~m}^{2}$ and measures about $190 \mathrm{~m}$ north/ south by $88 \mathrm{~m}$ east/west. The site is at an elevation of 1,380 feet ASL. The eastern half of the site lies on Abilene soils, while the western half lies on Leeray soils. Both of these soil types are considered to have a low probability for buried cultural deposits (Wormser and Sullo-Prewitt 2001). Surface visibility ranged from 20 to 100 percent depending on grass cover, with grass sparse or absent on the berms and dense in between. Numerous small, young mesquite trees dot the site.

The site is a large lithic scatter. Artifacts observed on the surface included one core or tested cobble, three bifaces, a medial section of an arrow point, over 60 tertiary flakes, over 25 secondary flakes, and over ten primary flakes. An almost complete Scallorn arrow point (Figure 13) was collected from the surface along the northwest edge of the site. The Scallorn point, as well as the medial arrow point section observed on
Five shovel tests, excavated on transects, fell within the site's boundaries: T3-ST6, T4-ST5, T4-ST6, T5-ST5, and T5-ST6. Artifacts were recovered from two of these. A single tertiary flake was recovered from T5-ST5 at 0-10 cm. A dart point, a Darl (Figure 13), was recovered from T5-ST6 at $10-20 \mathrm{~cm}$ bs. As noted, Darl points date to the Late Archaic (Collins 1995; Turner and Hester 1993). A total of eight additional shovel tests were excavated, six of which fell on site. Artifacts were recovered from two of these. A single tertiary flake was recovered from ST 5 at $10-20 \mathrm{~cm}$ bs. Shovel Test 7 recovered seven flakes between 0 and $30 \mathrm{~cm}$ bs. Note this shovel test also had sandstone present and had high soil susceptibility values for levels two and three (10 to $30 \mathrm{~cm} \mathrm{bs).} \mathrm{These} \mathrm{values} \mathrm{and} \mathrm{the} \mathrm{pres-}$ ence of artifacts and sandstone suggest that a buried feature or surface may be present at this location.

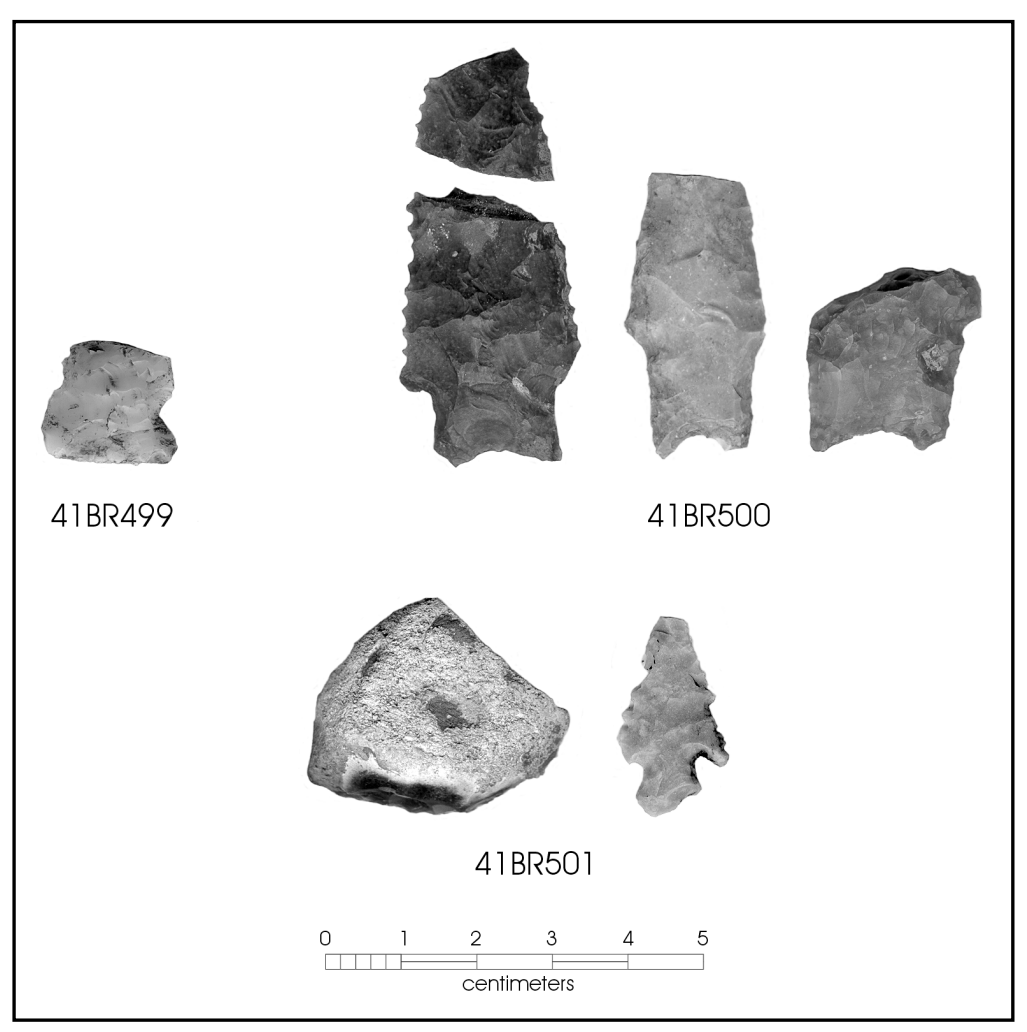

Figure 13. Selected artifacts collected from sites 41BR499, $41 B R 500$, and $41 B R 501$. 
the surface, suggests a Late Prehistoric component to this site, with the Scallorn falling within the early part of the Late Prehistoric (Collins 1995; Hester 1995; Turner and Hester 1993). Historic artifacts observed at the site included four pieces of purple "solarized" glass, and a few unidentified metal fragments. Spent bullets are also common in this area.

Four shovel tests excavated on the transects fell within the site's boundaries: T9-ST5, T9ST6, T11-ST4, and T11-ST5. In addition, two shovel tests fell just on the site's edges: T7ST5 and T11-ST6. A unifacially modified primary flake, worked along one edge, was the only artifact recovered from these shovel tests. The artifact came from T11-ST5, at 40$50 \mathrm{~cm}$ bs. Subsequently, two additional shovel tests were excavated within the site, neither of which contained any artifacts.
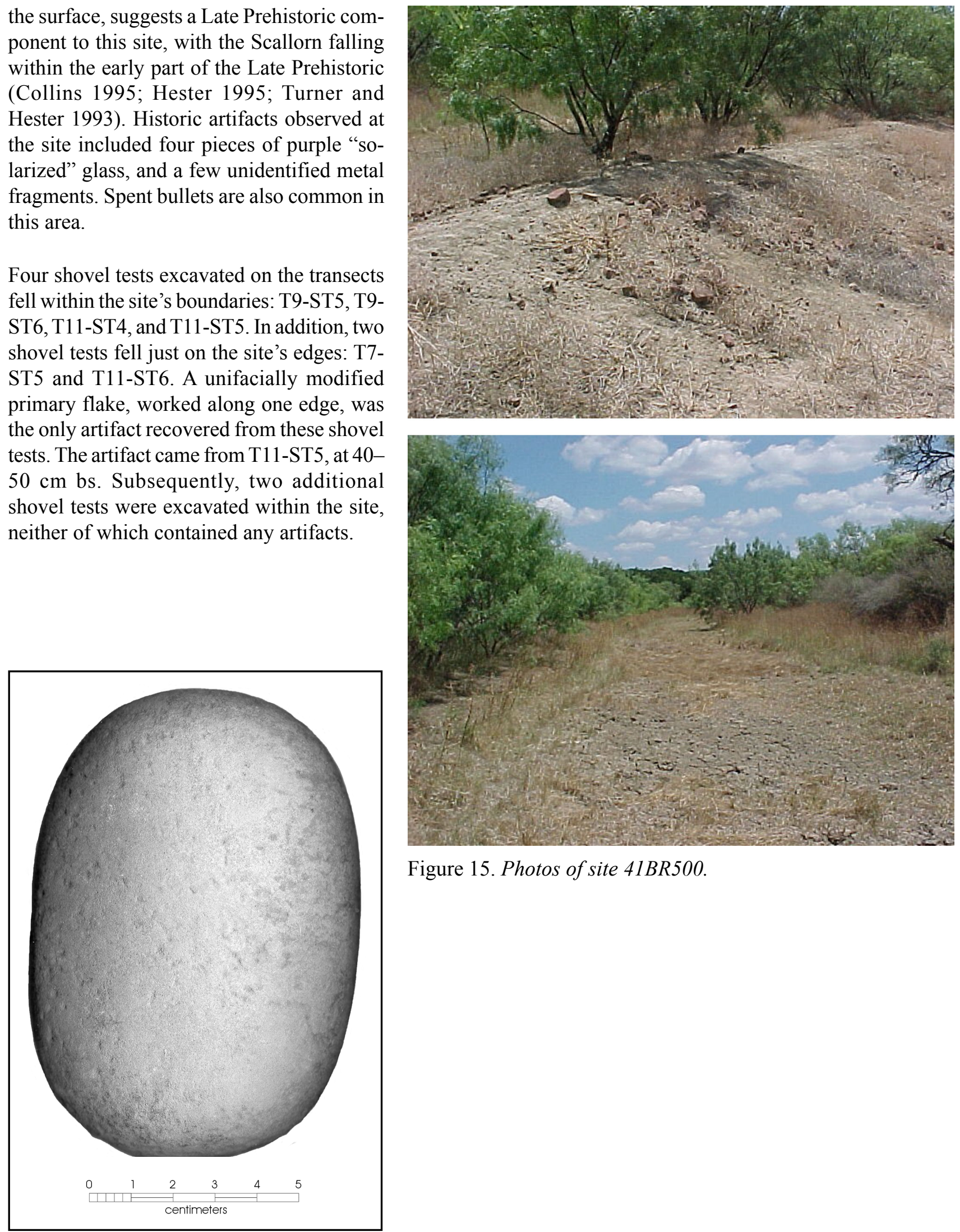

Figure 15. Photos of site 41 BR500.

Figure 16. Mano collected from surface of 41BR500. 


\section{Chapter 6: Project Summary and Recommendations}

In February, March, and May of 2001, personnel from the Center for Archaeological Research, The University of Texas at San Antonio, conducted a cultural resource inventory survey, involving pedestrian survey and shovel testing, of a 90 -acre $\left(364,060 \mathrm{~m}^{2}\right)$ tract of land on Camp Bowie, Brown County, Texas. A total of 104 shovel tests were systematically placed within the 90 -acre area. The survey identified three prehistoric sites, all lithic scatters defined by surface material, and twelve additional shovel tests were placed on these three sites. An arrow point fragment and nearly complete arrow point, collected from the surface of 41BR499 and 41BR501 respectively, suggest a Late Prehistoric affiliation for these sites. Dart points collected from 41BR500 suggest a Late Archaic temporal affiliation. In addition, a single whole mano was collected from the surface of 41BR500.

A total of five shovel tests were placed within 41BR499. Only one of the five was positive with the recovery of a single chert flake from Level 2, 10-20 $\mathrm{cm}$ bs. No features were observed at the site. Plowing of the field has impacted the distribution of surface artifacts. While a single projectile point was collected from the surface, the remaining surface artifacts are debitage. Recording of the surface artifacts has exhausted the data potential of this site. As such, we recommend that this site is not eligible for inclusion to the National Register of Historic Places, or for designation as a State Archeological Landmark.

In the case of 41BR500, a total of 11 shovel tests were placed within the site. Four of these were positive, with recovery limited to the upper $30 \mathrm{~cm}$. While much of the site appears to be disturbed by plowing and possibly trenching activities, some portion of the site is located on the edge of the field. This portion has not been disturbed. Subsurface deposits are present in this unplowed area, and shovel test results, supported by high soil susceptibility values, suggest the presence of a buried feature or surface around ST 7. In addition, 41BR500 contains both high artifact density and variety. Diagnostic projectile points, including one recovered from a buried context, suggest a Late Archaic temporal placement. CAR recommends that 41BR500 is potentially eligible for inclusion to the National Register of Historic Places, and designation as a State Archeological Landmark. Further testing of 41BR500 in the undisturbed portions, centered near ST 7, is necessary to determine the eligibility status of this site.

A total of eight shovel tests were placed on 41BR501. Only one of these shovel tests were positive with the recovery of a single marginally retouched flake from Level 5, 40-50 cm bs. No features were observed at the site. Plowing has impacted the surface distribution of artifacts. While a single projectile point was collected from the surface, the remaining surface artifacts are debitage. As such, recording of the surface artifacts has exhausted the data potential of this site. We recommend that this site is not eligible for inclusion to the National Register of Historic Places, or for designation as a State Archeological Landmark. 


\section{References Cited}

Black, S. L.

1986 The Clemente and Herminia Hinojosa Site, 41JW8: A Toyah Horizon Campsite in Southern Texas. Special Report No. 18. Center for Archaeological Research, The University of Texas at San Antonio.

1989a Central Texas Plateau Prairie. From the Gulf Coast to the Rio Grande: Human Adaptation in Central, South and Lower Pecos Texas, by T. R. Hester, S. L. Black, D. G. Steele, B. W. Olive, A. A. Fox, K. J. Reinhard, and L. C. Bement, pp. 17-38. Research Series No. 33. Arkansas Archeological Survey, Fayetteville.

1989b South Texas Plains. From the Gulf Coast to the Rio Grande: Human Adaptation in the Central, South, and Lower Pecos Texas, by T. R. Hester, S. L. Black, D. G. Steele, B. W. Olive, A. A. Fox, K. J. Reinhard, and L. C. Bement, pp. 39-62. Research Series No. 33. Arkansas Archeological Survey, Fayetteville.

Black, S. L., and A. J. McGraw

1985 The Panther Springs Creek Site: Cultural Change and Continuity in the Upper Salado Creek Drainage, South-Central Texas. Archaeological Survey Report, No. 100. Center for Archaeological Research, The University of Texas at San Antonio.

Black, S. L., L. W. Ellis, D. G. Creel, and G. T. Goode

1997 Hot Rock Cooking on the Greater Edwards Plateau: Four Burned Rock Midden Sites in West Central Texas (two volumes). Studies in Archeology No. 22. Texas Archeological Research Laboratory, The University of Texas at Austin. Archeology Studies Program, Report 2, Texas Department of Transportation Environmental Affairs Department, Austin.

Bousman, C. B.

1998 Paleoenvironmental Change in Central Texas: The Palynological Evidence. Plains Anthropologist 43(164):201-219.

Briggs, A. K.

1992 An Archaeological Survey of Sample Areas within the Proposed Camp Bowie Acquisition Area, near Brownwood, Brown County, Texas. Manuscript on file at the Texas Historical Commission, Austin.

Campbell, T. N.

1952 Early Archaeological Investigations in the Vicinity of Brownwood Texas. The Record 10(3):10-14.

Campbell, T. N., and T. J. Campbell

1981 Historic Indians of the Choke Canyon Reservoir Surrounding Area, Southern Texas. Choke Canyon Series, No. 1. Center for Archaeological Research, The University of Texas at San Antonio.

Clower, D. F.

1980 Soil Survey of Brown and Mills County, Texas. United States Department of Agriculture, Soil Conservation Service and the Texas Agricultural Experimental Station.

Collins, M. B.

1995 Forty Years of Archeology in Central Texas. Bulletin of the Texas Archeological Society 66:361-400. 
Creel, D. G.

1986 A Study of Prehistoric Burned Rock Middens in West Central Texas. Unpublished Ph.D. dissertation, The University of Arizona, Tucson.

Dillehay, T.

1974 Late Quaternary Bison Population Changes on the Southern Plains. Plains Anthropologist 19(64):180196.

Adjutant General's Department of Texas

1992 Environmental Assessment, Camp Bowie Land Acquisition. Adjutant General's Department of Texas, Facilities and Engineering, Austin, Texas.

Fenneman, N.

1931 Physiography of the Western United States. McGraw Hill, New York.

Fox, A. A., and D. E. Fox

1967 The Classen Rockshelter, 41BX23. Manuscript on file, Center for Archaeological Research, The University of Texas at San Antonio.

Gearhart, B., and M. W. Voellinger

1986 Archaeological Testing on Sites 41BR313 and 41BR314, Brown County, Texas. Manuscript on file, Texas Historical Commission, Austin.

Givens, R. D.

1968 A Preliminary Report on Excavations at Hitzfelder Cave. Bulletin of the Texas Archeological Society $38: 47-50$.

Goode, G. T.

1991 Late Prehistoric Burned Rock Middens in Central Texas, In The Burned Rock Middens of Texas: An Archeological Symposium, edited by T. R. Hester, pp. 71-93. Studies in Archeology No. 13. Texas Archeological Research Laboratory, The University of Texas at Austin.

Gose, W. A., and D. L. Nickels

2001[1998] Archaeomagnetic and Magnetic Susceptibility Analyses. In Test Excavations at the Culebra Creek Site, 41BX126, Bexar County, Texas. D. L. Nickels, C. B. Bousman, J. D. Leach, and D. A. Cargill, pp. 204-214. Archaeological Survey Report, No. 265, Center for Archaeological Research, The University of Texas at San Antonio. Archeology Studies Program, Report 3, Environmental Affairs Division, Texas Department of Transportation, Austin.

Gould, F. W.

1975 Texas Plants-A Checklist and Ecological Summary. Bulletin MP-585:5-14. Texas Agricultural Experimentation Station, College Station.

Hall, G. D.

1981 Allens Creek: A Study in the Cultural Prehistory of the Brazos River Valley, Texas. Research Report No. 61. Texas Archeological Survey, The University of Texas at Austin. 
Hester, T. R.

1991 The Burned Rock Middens of Texas: An Archeological Symposium. Studies in Archeology No. 13, Texas Archeological Research Laboratory, The University of Texas at Austin.

1995 The Prehistory of South Texas. Bulletin of the Texas Archeological Society 66:427-459.

Highley, L., C. Graves, and G. Judson

1978 Archeological Investigations at Scorpion Cave (41ME7), Medina County, Texas. Bulletin of the Texas Archeological Society 49:139-194.

Hofman, J. L.

1989 Prehistoric Culture History-Hunters and Gatherers in the Southern Great Plains. In From Clovis to Comanchero: Archeological Overview of the Southern Great Plains, by J. L. Hofman, R. L. Brooks, J. S. Hays, D. W. Owsley, R. L. Jantz, M. K. Marks, and M. H. Manhein, pp. 25-60. Research Series No. 35, Arkansas Archeological Survey, Fayetteville.

Houk, B. A., and J. C. Lohse

1993 Archeological Investigations at the Mingo Site, Bandera County, Texas. Bulletin of the Texas Archeological Society 61:193-247.

Howard, M. A.

1991 Burned Rock Midden Excavations, Hearths and Botanical Remains. In The Burned Rock Middens of Texas: An Archeological Symposium, edited by T. R. Hester, pp. 45-69. Studies in Archeology No. 13, Texas Archeological Research Laboratory, The University of Texas at Austin.

Huebner, J. A.

1991 Late Prehistoric Bison Populations in Central and Southern Texas. Plains Anthropologist 36(137):343358.

Hurt, R. D.

1980 Archeological Investigations of Portions of the Middle Concho Valley. Unpublished master's thesis, Texas Tech University, Lubbock.

Johnson, L., Jr.

1995 Past Cultures and Climates at Jonas Terrace, 41ME29, Medina County, Texas. Office of the State Archeologist, Report 40. Texas Department of Transportation and Texas Historical Commission, Austin.

Johnson, E., and V. T. Holliday

1986 The Archaic Record at Lubbock Lake. In Current Trends in Southern Plains Archeology, edited by T. G. Baugh. Plains Anthropologist Memoir 22:7-54.

Johnson, L., and G. T. Goode

1994 A New Try at Dating and Characterizing Holocene Climates, as well as Archeological Periods, on the Eastern Edwards Plateau. Bulletin of the Texas Archeological Society 65:1-51.

Kegley, G. P., and A. Black

1978 An Archeological Survey of Cordell and Camp Bowie City Park Sites, Brownwood, Texas. Texas Antiquities Committee, Austin, Texas. 
Kirby, F. E., and R. Moir

1976 Brownwood Dam Modifications and Archaeological Assessment. Reports in Archaeology No. 95. Archaeology Research Program, Southern Methodist University, Dallas.

Leach, J. D., and C. B. Bousman

2001[1998] Cultural and Secondary Formation Processes: On the Dynamic Accumulation of Burned Rock Middens. In Test Excavations at the Culebra Creek Site, 41BX126, Bexar County, Texas, pp. 119-145. Archaeological Survey Report, No. 265, Center for Archaeological Research, The University of Texas at San Antonio. Archeology Studies Program, Report 3, Environmental Affairs Division, Texas Department of Transportation, Austin.

Lukowski, P. D.

1988 Archaeological Investigations at 41BX1, Bexar County, Texas. Archaeological Survey Report, No. 135. Center for Archaeological Research, The University of Texas at San Antonio.

McClean, R. G., and W. F. Kean

1993 Contributions of Wood Ash Magnetism to Archeomagnetic Properties of Fire Pits and Hearths. Earth and Planetary Science Letters 119:387-394.

Meissner, B. A.

1993 Where the Buffalo Roam: Archaeological Evidence of Bison Populations in South and Central Texas. Manuscript on file, Center for Archaeological Research, The University of Texas at San Antonio.

Nance, H. S., and E. G. Wermund

1993 Geological and Climatic Survey: Camp Bowie Military Reservation, Brownwood Texas. Bureau of Economic Geology, The University of Texas at Austin, Texas.

Nature Conservancy of Texas

1996 Land Cover Analysis of Texas Army National Guard Training Sites. Report submitted to the Texas Adjutant General's Department.

Nickels, D. L., C. B. Bousman, J. D. Leach, and D. A. Cargill

2001[1998] Test Excavations at the Culebra Creek Site, 41BX126, Bexar County, Texas. Archaeological Survey Report, No. 265, Center for Archaeological Research, The University of Texas at San Antonio; Archeology Studies Program, Report 3, Environmental Affairs Division, Texas Department of Transportation, Austin.

Patterson, L. W.

1988 Intergroup Conflict in Prehistoric Texas. Houston Archeological Society Journal 90:8-10.

Prewitt, E. R.

1974 Archeological Investigations at the Loeve-Fox Site, Williams County, Texas. Research Report 49. Texas Archeological Survey, The University of Texas at Austin.

1981 Culture Chronology in Central Texas. Bulletin of the Texas Archeological Society 52:65-89.

1985 From Circleville to Toyah: Comments on Central Texas Chronology. Bulletin of the Texas Archeological Society 54:201-238.

1991 Burned Rock Middens: A Summary of Previous Investigations and Interpretations. In The Burned Rock Middens of Texas: An Archeological Symposium, edited T. R. Hester, pp. 25-32. Studies in Archeology No. 13. Texas Archeological Research Laboratory, The University of Texas at Austin. 
Prikryl, D. J.

1983 An Archaeological Survey of the City of Brownwood Proposed Sanitary Landfill Site, Brown County, Texas. Prewitt and Associates, Austin, Texas.

Reynolds, R. L., and J. W. King

1995 Magnetic Records of Climate Change. U.S. National Report to I.U.G.G., 1991-1994. American Geophysical Union. <http://www.agu.ong/revgeophys/reyno100/reyno100.html> Viewed May 2001.

Shafer, H. J., E. P. Baxter, and P. Dering

1975a Upper Pecan Bayou Watershed, Brown County, Texas: An Archaeological Survey of Structure No. 30. Archaeological Research Laboratory, Texas A\&M University, College Station.

1975b Brownwood Laterals Watershed, Brown County Texas: Archaeological Surveys of Floodwater Retarding Structures 1, Z24, 5, 18, 24 and 2. Report No. 13, Archaeological Research Laboratory, Texas A\&M University, College Station.

Singer, M. J., and P. Fine

1989 Pedogenic Factors Affecting Magnetic Susceptibility of Northern California Soils. Soil Science of America Journal 53:1119-1127.

Skelton, D. W.

1977 Archeological Investigations at the Fayette Power Project, Fayette County, Texas. Research Report No. 60. Texas Archeological Survey, The University of Texas at Austin.

Skinner, S. A.

1981 Aboriginal Demographic Changes in Central Texas. Plains Anthropologist 26(92):111-118.

Steele, D. G., and C. Assad Hunter

1986 Analysis of Vertebrate Faunal Remains from 41MC222 and 41MC296, McMullen County, Texas. In The Prehistoric Sites at Choke Canyon Reservoir, Southern Texas: Results of Phase II Archaeological Investigations, edited by G. D. Hall, T. R. Hester, and S. L. Black. Choke Canyon Series, No. 10. Center for Archaeological Research, The University of Texas at San Antonio.

Story, D. A.

1985 Adaptive Strategies of Archaic Cultures of the West GulfCoastal Plain. In Prehistoric Food Production in North America, edited by R. I. Ford, pp. 19-56. Anthropological Papers No. 75. Museum of Anthropology, University of Michigan, Ann Arbor.

Swanson, E. R.

1995 Geo-Texas. A Guide to the Earth Sciences. Texas A\&M University Press, College Station, Texas.

Taylor, A. J., and C. L. Highley

1995 Archeological Investigations at the Loma Sandia Site (41LK28): A Prehistoric Campsite in Live Oak County, Texas. 2 volumes. Studies in Archeology No. 20. Texas Archeological Research Laboratory, The University of Texas at Austin.

Texas Parks and Wildlife Department [TPWD]

1994 Biological Inventory of Camp Bowie. Prepared for the Texas National Guard by the Texas Heritage Program Resource Protection Division of the Texas Parks and Wildlife Department, Austin, Texas. 
Turner, E. S., and T. R. Hester

1993 A Field Guide to Stone Artifacts of Texas Indians. Gulf Publishing Company, Houston.

Weir, F. A.

1976 The Central Texas Archaic. Unpublished Ph.D. dissertation. Anthropology Department, Washington State University.

Wormser, A. J., and S. Sullo-Prewitt

2001[1999] Cultural Resources Inventory of Camp Bowie, Brownwood, Texas. Survey Report, No. 317, Center for Archaeological Research, The University of Texas at San Antonio; The Adjutant General's Department of Texas, Texas Army National Guard, Austin, Texas.

Wormser, A. J., G. P. Davis, and C. Leshley

1994 Archaeological Investigation of Proposed Camp Bowie Firebreak, Brown County, Texas. The Adjutant General's Department of Texas. Manuscript on file at the Texas Historical Commission, Austin.

Wormser, A. J., D. M. Sullo, and S. C. Stringer

1997 Archaeological Investigations of the Proposed Tank Training Area at Camp Bowie, Brown County, Texas. The Adjutant General's Department of Texas. Manuscript on file at the Texas Historical Commission, Austin. 



\section{Appendix A}

\section{Magnetic Soil Susceptibility Testing}




\section{Magnetic Soil Susceptibility Testing}

This appendix provides a brief discussion of magnetic susceptibility testing on sediments collected from the current project. In addition, the raw data used in Chapter 5 are presented.

The magnetic susceptibility (MS) of a given sediment sample can be thought of as a measure of how easily that sample can be magnetized (Dearing 1999; Gose and Nickels 2001). At low magnetic field strengths, this measure is primarily related to the concentration and grain size of ferro and ferromagnetic minerals in the sample. A number of processes can result in an increase in MS values in a sediment sample. Of these processes, those that are of concern here are related to an increase in the organic constitutes or changes in the mineralogy of sediments in a given sample (see Collins et al. 1994; McClean and Kean 1993; Singer and Fine 1989). Sediments with higher organic content tend to have higher magnetic susceptibility values, probably as a result of the production of maghemite, an iron oxide, during organic decay (Reynolds and King 1995). Pedogenic processes, such as soil formation and weathering, can result in the concentration of organic material, as well as alterations in the mineralogy of a given zone. These processes can significantly impact susceptibility readings. Cultural processes, such as the concentration of ash, charcoal, and refuse, would also produce higher MS readings. A measure of the magnetic susceptibility of a sediment sample, then, may provide information on both the presence of surfaces, as well as a measure of the concentration of cultural activity upon those surfaces.

\section{Collection Procedures and Laboratory Methods}

A total of 573 samples were collected for magnetic sediment susceptibility from the current project. The samples were collected from both transects and site specific shovel tests from $10-\mathrm{cm}$ levels. These samples were placed in plastic bags and sent to CAR for laboratory analysis. Sediment samples were air dried on a non-metal surface. After drying, the samples were then ground to a uniform grain size using a ceramic mortar and pestle. This was done to standardize particle size and make the material easier to handle and pack into sample containers. After each sample was ground, the mortar and pestle was washed with tap water and wiped dry with a paper towel to avoid cross-sample contamination. The ground sample was then poured into a plastic cube with external dimensions of $2.54 \mathrm{x}$ $2.54 \times 1.94 \mathrm{~cm}$. The cubes have an average weight of 4.85 grams. The sediment filled cube was then weighed, and the weight of the sample calculated by subtracting the empty cube weight. This was done to correct for differences in mass. Assuming that sample volume and material is similar, larger samples will have higher susceptibility values simply as a function of greater mass.

The cube was then placed into a MS2B Dual Frequency Sensor that, in conjunction with a MS2 Magnetic Susceptibility Meter, provided a measure of the magnetic susceptibility of the sample (see Dearing 1999). For each cube, three distinct readings were taken using the standard international (SI) scale. These readings were then averaged to provide a single measure. The value, referred to as volume specific susceptibility and noted with the symbol K. (Kappa), is recorded on a scale of $10^{-5}$, though there are no units associated with the value. That is, the value is dimensionless (Dearing 1999).

In order to correct for differences in sample weights, and provide units to the value $K$, the mass specific susceptibility value (X) was calculated using the formula

$$
\mathrm{X}=\left(\mathrm{K}_{0} / \mathrm{p}\right)
$$

where $\mathrm{p}$ is the sample bulk density expressed in $\mathrm{kg} \mathrm{m}^{-3}$. The bulk density is determined by dividing the sample mass by volume. However, as all samples were measured in identical cubes, and all cubes were full, the sample volume is assumed to be constant. Only the 
mass of the sample varied. Mass specific susceptibility can be determined by

$$
\mathrm{X}=\mathrm{K}_{\mathrm{o}} * \text { calibrated mass/ sample mass }
$$

where sample mass is determined by subtracting the cube weight from the total sample weight (Dearing 1999). Calibrated mass is assumed to be 10 grams.

While the resulting values now have both a scale and associated units, the critical element for the current discussion is related to relative differences between X sample values within a given profile or site, rather than absolute differences. That is, the principal interest is in rapid changes in the mass specific susceptibility values along a profile. This change may signal either a buried surface and/or cultural activity at that location. Comparisons of absolute values between samples from different areas, especially when the parent material of the soils is different, are of limited utility given our current goals.

Table A-1 lists a variety of examples of mass-specific susceptibility values for several different materials. In all cases, the analysis was performed following the procedures outlined above. The values differ widely, from a low of -1.47 for tap water, to a high of 97.62 for sediments collected from a burned-rock midden. Samples 5 and 6 are on two different clays from the same general setting, far northern Lamar County in north Texas. The mass-specific susceptibility is different for these samples, probably as a function of different frequencies of trace elements that, though small in absolute quantity, can dramatically impact the susceptibility values.

The potential impacts of cultural processes on susceptibility values can be seen by considering a data set collected from an archaeological site located in Brown County, 41BR473. A total of 279 sediment susceptibility samples were collected from each level of over 50 shovel tests placed at this site. In all cases, the analytical procedures followed those outlined previously. Table A-2 presents summary data on all 279 cases, along with susceptibility scores for those settings that had fire-cracked rock (FCR) or chipped stone present. If cultural inputs result in higher susceptibility values, then it should be the case that significantly higher susceptibility values will be present in levels that have cultural material.

An examination of Table A-2 will demonstrate that this is indeed the case. Levels that have FCR present do have higher scores relative to those that lack FCR. Similarly, those levels that have chipped stone present have a higher average mass specific susceptibility score relative to those that lack chipped stone. As the distribution is approximately normal, a t-test was used to test the overall significance of these differences. In both the FCR and chipped stone comparisons, the test

Table A-1. Magnetic Soil Susceptibility Data for a Variety of Substances

\begin{tabular}{|l|c|c|c|c|c|c|c|}
\hline Sample Type & $\begin{array}{c}\text { Total } \\
\text { Wt. (gr.) }\end{array}$ & $\begin{array}{c}\text { Sample } \\
\text { Wt. (gr.) }\end{array}$ & $\begin{array}{c}\text { Reading } \\
\mathbf{1}(\mathbf{k})\end{array}$ & $\begin{array}{c}\text { Reading } \\
\mathbf{2}(\mathbf{k})\end{array}$ & $\begin{array}{c}\text { Reading } \\
\mathbf{3} \mathbf{( k )}\end{array}$ & $\begin{array}{c}\text { Average } \\
\mathbf{K}\end{array}$ & $\begin{array}{c}\text { Corrected } \\
\text { Mass (X) }\end{array}$ \\
\hline $\begin{array}{l}\text { 1) Sandy sediment } \\
\text { with organics }\end{array}$ & 13.7 & 8.85 & 27.9 & 28 & 28.1 & 28.00 & 31.64 \\
\hline $\begin{array}{l}\text { 2) Modern mesquite } \\
\text { charcoal and sediment }\end{array}$ & 9.4 & 4.55 & 10.7 & 10.8 & 10.7 & 10.73 & 23.59 \\
\hline $\begin{array}{l}\text { 3) Modern oak } \\
\text { wood ash }\end{array}$ & 7.5 & 2.65 & 16.1 & 16.2 & 16.2 & 16.17 & 61.01 \\
\hline $\begin{array}{l}\text { 4) Sediment from } \\
\text { burned rock midden }\end{array}$ & 11.3 & 6.45 & 62.9 & 63 & 63 & 62.97 & 97.62 \\
\hline $\begin{array}{l}\text { 5) Grey clay - } \\
\text { no human occupation }\end{array}$ & 12.6 & 7.75 & 10.4 & 10.3 & 10.4 & 10.37 & 13.38 \\
\hline $\begin{array}{l}\text { 6) Red clay - } \\
\text { no human occupation }\end{array}$ & 10.8 & 5.95 & 11.9 & 12 & 12 & 11.97 & 20.11 \\
\hline 7) Sandstone & 14.7 & 9.85 & 6.9 & 7 & 7.1 & 7.00 & 7.11 \\
\hline 8) Limestone & 12.7 & 7.85 & -0.5 & -0.5 & -0.5 & -0.50 & -0.64 \\
\hline 9) Tap water & 10.5 & 5.65 & -0.8 & -0.8 & -0.9 & -0.83 & -1.47 \\
\hline
\end{tabular}


Table A-2. Presence/absence of Cultural Material and Mass Specific Soil Susceptibility Values for Shovel Tests at 41BR473

\begin{tabular}{|l|c|c|c|c|c|}
\hline & $\begin{array}{c}\text { All } \\
\text { Cases }\end{array}$ & $\begin{array}{c}\text { FCR } \\
\text { Present }\end{array}$ & $\begin{array}{c}\text { FCR } \\
\text { Absent }\end{array}$ & $\begin{array}{c}\text { Chipped Stone } \\
\text { Present }\end{array}$ & $\begin{array}{c}\text { Chipped Stone } \\
\text { Absent }\end{array}$ \\
\hline $\begin{array}{c}\text { Number } \\
\text { of Samples }\end{array}$ & 279 & 84 & 195 & 38 & 241 \\
\hline Mean Value & 48.3 & 56.9 & 44.6 & 55.2 & 47.2 \\
\hline $\begin{array}{c}\text { Standard } \\
\text { Deviation }\end{array}$ & 17.2 & 17.7 & 15.6 & 16.1 & 17.1 \\
\hline
\end{tabular}

confirms that those levels with cultural material have significantly higher scores than those without cultural material (FCR t-statistic $=5.804, \mathrm{df}=277, \mathrm{p}<.001$; chipped stone t-statistic $=2.674, \mathrm{df}=277, \mathrm{p}=.008$ ). Our preliminary investigations, then, coupled with the previous work application, clearly suggest that an analysis of the magnetic susceptibility of sediment can provide additional information on both the presence of buried surfaces, as well as the impact of cultural material on those surfaces.

\section{Data Presentation}

Tables A-3 and A-4 present the raw data for both transect and non-transect shovel tests. These raw data are summarized in Chapter 5. Note that the mass corrected soil susceptibility values are referred to as MSS values in the tables. The final column in Table A-3 identifies whether or not a transect sample was within a site boundary: $0=$ off site, $1=$ on site. 
Table A-3. Soil Susceptibility Data for Transects

\begin{tabular}{|c|c|c|c|c|c|c|c|c|c|c|}
\hline Transect & Shovel Test & Level & Weight (g) & Read 1 & Read 2 & Read 3 & Average & Correct wt. & MSS Value & On Site \\
\hline 1 & 2 & 1 & 11.8 & 38.9 & 39.1 & 39.2 & 39.1 & 6.95 & 56.21 & 1 \\
\hline 1 & 2 & 2 & 11.6 & 35.3 & 35.6 & 35.1 & 35.3 & 6.75 & 52.35 & 1 \\
\hline 1 & 2 & 3 & 12.5 & 45.6 & 45.6 & 45.7 & 45.6 & 7.65 & 59.65 & 1 \\
\hline 1 & 2 & 4 & 12.1 & 41.7 & 41.5 & 41.8 & 41.7 & 7.25 & 57.47 & 1 \\
\hline 1 & 2 & 5 & 11.7 & 53.6 & 53.6 & 54.4 & 53.9 & 6.85 & 78.64 & 1 \\
\hline 1 & 2 & 6 & 12 & 34.4 & 34.5 & 34.4 & 34.4 & 7.15 & 48.16 & 1 \\
\hline 1 & 3 & 1 & 12.2 & 53.3 & 53 & 53 & 53.1 & 7.35 & 72.24 & 0 \\
\hline 1 & 3 & 2 & 11.9 & 52.3 & 52.2 & 52.5 & 52.3 & 7.05 & 74.23 & 0 \\
\hline 1 & 3 & 3 & 11.6 & 46.7 & 46.8 & 45.9 & 46.5 & 6.75 & 68.84 & 0 \\
\hline 1 & 3 & 4 & 11.8 & 41.8 & 41.9 & 41.7 & 41.8 & 6.95 & 60.14 & 0 \\
\hline 1 & 3 & 5 & 11.5 & 27.6 & 27.6 & 27.3 & 27.5 & 6.65 & 41.35 & 0 \\
\hline 1 & 3 & 6 & 11.9 & 23.9 & 23.7 & 23.7 & 23.8 & 7.05 & 33.71 & 0 \\
\hline 1 & 4 & 1 & 12.4 & 61.6 & 61.3 & 61.4 & 61.4 & 7.55 & 81.37 & 0 \\
\hline 1 & 4 & 2 & 12.3 & 57.8 & 57.9 & 58 & 57.9 & 7.45 & 77.72 & 0 \\
\hline 1 & 4 & 3 & 12.8 & 61.1 & 61.5 & 61.4 & 61.3 & 7.95 & 77.15 & 0 \\
\hline 1 & 4 & 4 & 12.8 & 63.1 & 62.9 & 62.8 & 62.9 & 7.95 & 79.16 & 0 \\
\hline 1 & 4 & 5 & 12.3 & 53.8 & 53.8 & 53.7 & 53.8 & 7.45 & 72.17 & 0 \\
\hline 1 & 5 & 1 & 12.5 & 54.5 & 54.8 & 55 & 54.8 & 7.65 & 71.59 & 0 \\
\hline 1 & 5 & 2 & 12.4 & 42.5 & 42.5 & 42.5 & 42.5 & 7.55 & 56.29 & 0 \\
\hline 1 & 5 & 3 & 12.5 & 47.7 & 47.1 & 47.5 & 47.4 & 7.65 & 62.00 & 0 \\
\hline 1 & 5 & 4 & 12.4 & 45.8 & 45.6 & 45.5 & 45.6 & 7.55 & 60.44 & 0 \\
\hline 1 & 5 & 5 & 12.4 & 46.1 & 45.9 & 45.9 & 46.0 & 7.55 & 60.88 & 0 \\
\hline 1 & 6 & 1 & 12.1 & 46.3 & 47.3 & 47.3 & 47.0 & 7.25 & 64.78 & 0 \\
\hline 1 & 6 & 2 & 11 & 37.2 & 36.4 & 37.7 & 37.1 & 6.15 & 60.33 & 0 \\
\hline 1 & 6 & 3 & 12.6 & 47.5 & 48.1 & 47.8 & 47.8 & 7.75 & 61.68 & 0 \\
\hline 1 & 6 & 4 & 10.8 & 34.4 & 33.6 & 33.6 & 33.9 & 5.95 & 56.92 & 0 \\
\hline 1 & 6 & 5 & 12.3 & 46.1 & 46.9 & 45.1 & 46.0 & 7.45 & 61.79 & 0 \\
\hline 2 & 2 & 1 & 10.6 & 34.6 & 36 & 36.9 & 35.8 & 5.75 & 62.32 & 1 \\
\hline 2 & 2 & 2 & 11.1 & 41.5 & 42.3 & 41.5 & 41.8 & 6.25 & 66.83 & 1 \\
\hline 2 & 2 & 3 & 11.1 & 37.2 & 35.7 & 36.6 & 36.5 & 6.25 & 58.40 & 1 \\
\hline 2 & 2 & 4 & 11.8 & 41.7 & 41 & 41.2 & 41.3 & 6.95 & 59.42 & 1 \\
\hline 2 & 2 & 5 & 11.6 & 41.2 & 41.1 & 41.1 & 41.1 & 6.75 & 60.94 & 1 \\
\hline 2 & 2 & 6 & 12.1 & 48.7 & 48.6 & 49.2 & 48.8 & 7.25 & 67.36 & 1 \\
\hline 2 & 3 & 1 & 12.7 & 63.9 & 64.1 & 64.1 & 64.0 & 7.85 & 81.57 & 0 \\
\hline 2 & 3 & 2 & 12.1 & 62.5 & 62 & 63.1 & 62.5 & 7.25 & 86.25 & 0 \\
\hline 2 & 3 & 3 & 11.9 & 58.7 & 59.1 & 58.7 & 58.8 & 7.05 & 83.45 & 0 \\
\hline 2 & 3 & 4 & 12.4 & 59 & 59.6 & 58.4 & 59.0 & 7.55 & 78.15 & 0 \\
\hline 2 & 3 & 5 & 12.5 & 51.5 & 51.5 & 51.1 & 51.4 & 7.65 & 67.15 & 0 \\
\hline 2 & 3 & 6 & 12.1 & 43.7 & 44 & 43.8 & 43.8 & 7.25 & 60.46 & 0 \\
\hline 2 & 4 & 1 & 11.4 & 48.6 & 48.2 & 48.3 & 48.4 & 6.55 & 73.84 & 0 \\
\hline 2 & 4 & 2 & 11.6 & 50.4 & 50.2 & 50.1 & 50.2 & 6.75 & 74.42 & 0 \\
\hline 2 & 4 & 3 & 11.5 & 58 & 57.5 & 57.5 & 57.7 & 6.65 & 86.72 & 0 \\
\hline 2 & 4 & 4 & 12.4 & 65.1 & 65.3 & 64.8 & 65.1 & 7.55 & 86.18 & 0 \\
\hline 2 & 4 & 5 & 11.4 & 55.6 & 55.6 & 55.1 & 55.4 & 6.55 & 84.63 & 0 \\
\hline 2 & 5 & 1 & 12.8 & 53.3 & 53 & 52.8 & 53.0 & 7.95 & 66.71 & 0 \\
\hline 2 & 5 & 2 & 12.5 & 50.9 & 50.3 & 50.4 & 50.5 & 7.65 & 66.06 & 0 \\
\hline 2 & 5 & 3 & 11.7 & 44.9 & 44.5 & 44.6 & 44.7 & 6.85 & 65.21 & 0 \\
\hline
\end{tabular}


Table A-3. continued...

\begin{tabular}{|c|c|c|c|c|c|c|c|c|c|c|}
\hline Transect & Shovel Test & Level & Weight $(\mathrm{g})$ & Read 1 & Read 2 & Read 3 & Average & Correct wt. & MSS Value & On Site \\
\hline 2 & 5 & 4 & 12.3 & 49 & 48.4 & 48.9 & 48.8 & 7.45 & 65.46 & 0 \\
\hline 2 & 5 & 5 & 12.3 & 47.7 & 47.5 & 47.5 & 47.6 & 7.45 & 63.85 & 0 \\
\hline 2 & 6 & 1 & 12.6 & 50.9 & 52.1 & 51.4 & 51.5 & 7.75 & 66.41 & 0 \\
\hline 2 & 6 & 2 & 12.8 & 52.5 & 52.5 & 52.5 & 52.5 & 7.95 & 66.04 & 0 \\
\hline 2 & 6 & 3 & 12.6 & 48.5 & 48.2 & 48.6 & 48.4 & 7.75 & 62.49 & 0 \\
\hline 2 & 6 & 4 & 12.3 & 45.8 & 45.7 & 45.3 & 45.6 & 7.45 & 61.21 & 0 \\
\hline 2 & 6 & 5 & 12.9 & 48.5 & 48.6 & 48.3 & 48.5 & 8.05 & 60.21 & 0 \\
\hline 3 & 2 & 1 & 11.4 & 44.3 & 45.3 & 45.3 & 45.0 & 6.55 & 68.65 & 1 \\
\hline 3 & 2 & 2 & 11.9 & 49.2 & 48.7 & 49.1 & 49.0 & 7.05 & 69.50 & 1 \\
\hline 3 & 2 & 3 & 11.6 & 51 & 51.8 & 50.7 & 51.2 & 6.75 & 75.80 & 1 \\
\hline 3 & 2 & 4 & 12.5 & 61.9 & 61.8 & 61.7 & 61.8 & 7.65 & 80.78 & 1 \\
\hline 3 & 2 & 5 & 12.2 & 59 & 58.4 & 58.7 & 58.7 & 7.35 & 79.86 & 1 \\
\hline 3 & 2 & 6 & 12.1 & 55.6 & 55.8 & 54.7 & 55.4 & 7.25 & 76.37 & 1 \\
\hline 3 & 2 & 7 & 12.7 & 58.2 & 58.2 & 57.9 & 58.1 & 7.85 & 74.01 & 1 \\
\hline 3 & 3 & 1 & 11.5 & 47.1 & 47.5 & 46.5 & 47.0 & 6.65 & 70.73 & 0 \\
\hline 3 & 3 & 2 & 12 & 53.7 & 53.6 & 53.8 & 53.7 & 7.15 & 75.10 & 0 \\
\hline 3 & 3 & 3 & 11.7 & 48.1 & 48.3 & 48.3 & 48.2 & 6.85 & 70.41 & 0 \\
\hline 3 & 3 & 4 & 12.2 & 59.9 & 60.3 & 60 & 60.1 & 7.35 & 81.72 & 0 \\
\hline 3 & 3 & 5 & 11.8 & 56.8 & 57.9 & 56.5 & 57.1 & 6.95 & 82.11 & 0 \\
\hline 3 & 3 & 6 & 12.5 & 63.9 & 64 & 64.1 & 64.0 & 7.65 & 83.66 & 0 \\
\hline 3 & 3 & 7 & 12.6 & 63.5 & 63.5 & 63.5 & 63.5 & 7.75 & 81.94 & 0 \\
\hline 3 & 4 & 1 & 11.5 & 43.6 & 43.1 & 43.3 & 43.3 & 6.65 & 65.16 & 0 \\
\hline 3 & 4 & 2 & 11.9 & 50.6 & 50.8 & 50.4 & 50.6 & 7.05 & 71.77 & 0 \\
\hline 3 & 4 & 3 & 12.1 & 45.5 & 45.7 & 45.5 & 45.6 & 7.25 & 62.85 & 0 \\
\hline 3 & 4 & 4 & 11.5 & 41.4 & 41.4 & 41.2 & 41.3 & 6.65 & 62.16 & 0 \\
\hline 3 & 4 & 5 & 11.8 & 44.4 & 44.4 & 44.8 & 44.5 & 6.95 & 64.08 & 0 \\
\hline 3 & 5 & 1 & 11.4 & 36 & 36.3 & 36 & 36.1 & 6.55 & 55.11 & 0 \\
\hline 3 & 5 & 2 & 12.3 & 45 & 45.8 & 45.1 & 45.3 & 7.45 & 60.81 & 0 \\
\hline 3 & 5 & 3 & 10.7 & 35 & 34.6 & 34.9 & 34.8 & 5.85 & 59.54 & 0 \\
\hline 3 & 5 & 4 & 11.7 & 43 & 43.4 & 42.7 & 43.0 & 6.85 & 62.82 & 0 \\
\hline 3 & 5 & 5 & 12.2 & 47.7 & 47.8 & 47.6 & 47.7 & 7.35 & 64.90 & 0 \\
\hline 3 & 6 & 1 & 11.5 & 38.7 & 38.6 & 38.3 & 38.5 & 6.65 & 57.94 & 1 \\
\hline 3 & 6 & 2 & 12.5 & 48.3 & 47.5 & 47.8 & 47.9 & 7.65 & 62.57 & 1 \\
\hline 3 & 6 & 3 & 12 & 51.6 & 51.4 & 51.1 & 51.4 & 7.15 & 71.84 & 1 \\
\hline 3 & 6 & 4 & 12.5 & 53.5 & 53.5 & 53.5 & 53.5 & 7.65 & 69.93 & 1 \\
\hline 3 & 6 & 5 & 12.5 & 52.4 & 52.2 & 52 & 52.2 & 7.65 & 68.24 & 1 \\
\hline 4 & 2 & 1 & 11.9 & 52.7 & 52.7 & 53.2 & 52.9 & 7.05 & 74.99 & 0 \\
\hline 4 & 2 & 2 & 12.1 & 57.1 & 56.7 & 56.7 & 56.8 & 7.25 & 78.39 & 0 \\
\hline 4 & 2 & 3 & 11.7 & 60.3 & 60.6 & 60.3 & 60.4 & 6.85 & 88.18 & 0 \\
\hline 4 & 2 & 4 & 11.8 & 58.1 & 58.1 & 57.7 & 58.0 & 6.95 & 83.41 & 0 \\
\hline 4 & 2 & 5 & 11.5 & 51.6 & 51.5 & 52.2 & 51.8 & 6.65 & 77.84 & 0 \\
\hline 4 & 3 & 1 & 12.1 & 47 & 47.3 & 47.2 & 47.2 & 7.25 & 65.06 & 0 \\
\hline 4 & 3 & 2 & 12.1 & 48.6 & 48.3 & 48.8 & 48.6 & 7.25 & 66.99 & 0 \\
\hline 4 & 3 & 3 & 11.9 & 50.7 & 50.3 & 50.1 & 50.4 & 7.05 & 71.44 & 0 \\
\hline 4 & 3 & 4 & 11.8 & 49.6 & 50.2 & 49.5 & 49.8 & 6.95 & 71.61 & 0 \\
\hline 4 & 3 & 5 & 12.2 & 52.2 & 52.1 & 51.6 & 52.0 & 7.35 & 70.70 & 0 \\
\hline 4 & 4 & 1 & 12.5 & 41.7 & 42.1 & 42.3 & 42.0 & 7.65 & 54.95 & 0 \\
\hline
\end{tabular}


Table A-3. continued...

\begin{tabular}{|c|c|c|c|c|c|c|c|c|c|c|}
\hline Transect & Shovel Test & \begin{tabular}{|l|l|} 
Level \\
\end{tabular} & Weight $(\mathrm{g})$ & Read 1 & Read 2 & Read 3 & Average & Correct wt. & MSS Value & On Site \\
\hline 4 & 4 & 2 & 11.9 & 39.6 & 39.6 & 39.2 & 39.5 & 7.05 & 55.98 & 0 \\
\hline 4 & 4 & 3 & 12.5 & 45.8 & 46.2 & 46.4 & 46.1 & 7.65 & 60.31 & 0 \\
\hline 4 & 4 & 4 & 12.5 & 45.7 & 45.6 & 45.4 & 45.6 & 7.65 & 59.56 & 0 \\
\hline 4 & 4 & 5 & 12.3 & 44.1 & 44.5 & 44.4 & 44.3 & 7.45 & 59.51 & 0 \\
\hline 4 & 5 & 1 & 11.5 & 38.8 & 38.7 & 38.4 & 38.6 & 6.65 & 58.10 & 1 \\
\hline 4 & 5 & 2 & 11.3 & 37.9 & 37 & 36.9 & 37.3 & 6.45 & 57.78 & 1 \\
\hline 4 & 5 & 3 & 11.1 & 35.9 & 35.8 & 35.3 & 35.7 & 6.25 & 57.07 & 1 \\
\hline 4 & 5 & 4 & 12 & 44.7 & 44.7 & 44.5 & 44.6 & 7.15 & 62.42 & 1 \\
\hline 4 & 5 & 5 & 12.5 & 48.7 & 48.9 & 48.3 & 48.6 & 7.65 & 63.57 & 1 \\
\hline 4 & 6 & 1 & 12.2 & 38.2 & 37.9 & 38.2 & 38.1 & 7.35 & 51.84 & 1 \\
\hline 4 & 6 & 2 & 12.4 & 44.3 & 44.2 & 44 & 44.2 & 7.55 & 58.50 & 1 \\
\hline 4 & 6 & 3 & 11.9 & 39.6 & 39.7 & 39.7 & 39.7 & 7.05 & 56.26 & 1 \\
\hline 4 & 6 & 4 & 12.5 & 42.3 & 42.9 & 42.4 & 42.5 & 7.65 & 55.60 & 1 \\
\hline 4 & 6 & 5 & 12.1 & 37.8 & 37.7 & 37.5 & 37.7 & 7.25 & 51.95 & 1 \\
\hline 5 & 2 & 1 & 10.9 & 41.6 & 41.6 & 41.8 & 41.7 & 6.05 & 68.87 & 0 \\
\hline 5 & 2 & 2 & 12.5 & 52.6 & 52.7 & 52.7 & 52.7 & 7.65 & 68.85 & 0 \\
\hline 5 & 2 & 3 & 12.2 & 53.7 & 53.4 & 53.5 & 53.5 & 7.35 & 72.83 & 0 \\
\hline 5 & 2 & 4 & 12.1 & 57.1 & 57.7 & 57.5 & 57.4 & 7.25 & 79.22 & 0 \\
\hline 5 & 2 & 5 & 12.2 & 59.3 & 59 & 59.7 & 59.3 & 7.35 & 80.73 & 0 \\
\hline 5 & 3 & 1 & 12.3 & 37.2 & 36.9 & 36.7 & 36.9 & 7.45 & 49.57 & 0 \\
\hline 5 & 3 & 2 & 12.3 & 41.8 & 41.8 & 41.7 & 41.8 & 7.45 & 56.06 & 0 \\
\hline 5 & 3 & 3 & 12.3 & 44.3 & 44.4 & 44.3 & 44.3 & 7.45 & 59.51 & 0 \\
\hline 5 & 3 & 4 & 12.4 & 45.9 & 45.7 & 45.9 & 45.8 & 7.55 & 60.71 & 0 \\
\hline 5 & 3 & 5 & 12.5 & 46.5 & 46.6 & 46.3 & 46.5 & 7.65 & 60.74 & 0 \\
\hline 5 & 4 & 1 & 12.4 & 40.4 & 40.9 & 40.8 & 40.7 & 7.55 & 53.91 & 0 \\
\hline 5 & 4 & 2 & 12.1 & 42.4 & 42.3 & 42.5 & 42.4 & 7.25 & 58.48 & 0 \\
\hline 5 & 4 & 3 & 12.5 & 46.4 & 46 & 46.1 & 46.2 & 7.65 & 60.35 & 0 \\
\hline 5 & 4 & 4 & 12.7 & 47.4 & 47.2 & 47.2 & 47.3 & 7.85 & 60.21 & 0 \\
\hline 5 & 4 & 5 & 13 & 48.5 & 48.7 & 48.8 & 48.7 & 8.15 & 59.71 & 0 \\
\hline 5 & 5 & 1 & 11.6 & 34.6 & 32.8 & 32.7 & 33.4 & 6.75 & 49.43 & 1 \\
\hline 5 & 5 & 2 & 12.1 & 41.7 & 41.7 & 41.4 & 41.6 & 7.25 & 57.38 & 1 \\
\hline 5 & 5 & 3 & 12 & 40.3 & 40.3 & 40.3 & 40.3 & 7.15 & 56.36 & 1 \\
\hline 5 & 5 & 4 & 12.1 & 39.1 & 39 & 38.9 & 39.0 & 7.25 & 53.79 & 1 \\
\hline 5 & 5 & 5 & 12.7 & 42.7 & 42.7 & 42.7 & 42.7 & 7.85 & 54.39 & 1 \\
\hline 5 & 6 & 1 & 11.6 & 32.7 & 32 & 33.6 & 32.8 & 6.75 & 48.54 & 1 \\
\hline 5 & 6 & 2 & 12 & 37.2 & 37.1 & 37 & 37.1 & 7.15 & 51.89 & 1 \\
\hline 5 & 6 & 3 & 11.9 & 36.3 & 37.3 & 37.3 & 37.0 & 7.05 & 52.43 & 1 \\
\hline 5 & 6 & 4 & 13 & 39.3 & 39.6 & 39.5 & 39.5 & 8.15 & 48.43 & 1 \\
\hline 5 & 6 & 5 & 12.3 & 33.9 & 33.8 & 33.9 & 33.9 & 7.45 & 45.46 & 1 \\
\hline 6 & 2 & 1 & 11.9 & 45.7 & 45.6 & 45.5 & 45.6 & 7.05 & 64.68 & 0 \\
\hline 6 & 2 & 2 & 12.2 & 46.1 & 46.3 & 46.5 & 46.3 & 7.35 & 62.99 & 0 \\
\hline 6 & 2 & 3 & 12.2 & 48.8 & 49.1 & 48.8 & 48.9 & 7.35 & 66.53 & 0 \\
\hline 6 & 2 & 4 & 11.6 & 43.4 & 42.9 & 43.5 & 43.3 & 6.75 & 64.10 & 0 \\
\hline 6 & 2 & 5 & 12.4 & 48.8 & 48.8 & 48.5 & 48.7 & 7.55 & 64.50 & 0 \\
\hline 6 & 3 & 1 & 12.8 & 35.4 & 36.4 & 36.4 & 36.1 & 7.95 & 45.37 & 0 \\
\hline 6 & 3 & 2 & 12.4 & 34.5 & 34 & 34.4 & 34.3 & 7.55 & 45.43 & 0 \\
\hline 6 & 3 & 3 & 12.8 & 36.2 & 36.6 & 36.5 & 36.4 & 7.95 & 45.83 & 0 \\
\hline
\end{tabular}


Table A-3. continued...

\begin{tabular}{|c|c|c|c|c|c|c|c|c|c|c|}
\hline Transect & Shovel Test & Level & Weight $(\mathrm{g})$ & Read 1 & Read 2 & Read 3 & Average & Correct wt. & MSS Value & On Site \\
\hline 6 & 3 & 4 & 12.5 & 34.9 & 35.6 & 35 & 35.2 & 7.65 & 45.97 & 0 \\
\hline 6 & 3 & 5 & 13 & 38.1 & 38.4 & 38 & 38.2 & 8.15 & 46.83 & 0 \\
\hline 6 & 4 & 1 & 12.2 & 38.2 & 35.7 & 38.9 & 37.6 & 7.35 & 51.16 & 0 \\
\hline 6 & 4 & 2 & 12.1 & 38.6 & 39.3 & 38.6 & 38.8 & 7.25 & 53.56 & 0 \\
\hline 6 & 4 & 3 & 12.8 & 42.1 & 41.5 & 42.2 & 41.9 & 7.95 & 52.75 & 0 \\
\hline 6 & 4 & 4 & 12.9 & 40 & 40.3 & 40 & 40.1 & 8.05 & 49.81 & 0 \\
\hline 6 & 4 & 5 & 13.1 & 43.2 & 43.9 & 43.4 & 43.5 & 8.25 & 52.73 & 0 \\
\hline 6 & 5 & 1 & 11.5 & 36.9 & 37 & 36.9 & 36.9 & 6.65 & 55.54 & 0 \\
\hline 6 & 5 & 2 & 11.8 & 39.2 & 39.2 & 39.2 & 39.2 & 6.95 & 56.40 & 0 \\
\hline 6 & 5 & 3 & 12.3 & 38.1 & 38.3 & 38 & 38.1 & 7.45 & 51.19 & 0 \\
\hline 6 & 5 & 4 & 13.2 & 42.3 & 42.6 & 42.7 & 42.5 & 8.35 & 50.94 & 0 \\
\hline 6 & 5 & 5 & 12.5 & 37.9 & 37.7 & 37.7 & 37.8 & 7.65 & 49.37 & 0 \\
\hline 6 & 6 & 1 & 11.9 & 42.7 & 43.5 & 42.6 & 42.9 & 7.05 & 60.90 & 0 \\
\hline 6 & 6 & 2 & 12.6 & 51.4 & 51.4 & 51.6 & 51.5 & 7.75 & 66.41 & 0 \\
\hline 6 & 6 & 3 & 12.9 & 53 & 53.2 & 53.1 & 53.1 & 8.05 & 65.96 & 0 \\
\hline 6 & 6 & 4 & 12.1 & 44.5 & 45.1 & 44.6 & 44.7 & 7.25 & 61.70 & 0 \\
\hline 6 & 6 & 5 & 12.1 & 45.2 & 44.6 & 46.4 & 45.4 & 7.25 & 62.62 & 0 \\
\hline 7 & 2 & 1 & 11.8 & 44.3 & 44 & 44 & 44.1 & 6.95 & 63.45 & 0 \\
\hline 7 & 2 & 2 & 12 & 44.7 & 44.8 & 45.3 & 44.9 & 7.15 & 62.84 & 0 \\
\hline 7 & 2 & 3 & 11.1 & 39.8 & 40.2 & 40.5 & 40.2 & 6.25 & 64.27 & 0 \\
\hline 7 & 2 & 4 & 11.7 & 46.1 & 45.7 & 45.9 & 45.9 & 6.85 & 67.01 & 0 \\
\hline 7 & 2 & 5 & 12.3 & 54.9 & 55.3 & 55 & 55.1 & 7.45 & 73.91 & 0 \\
\hline 7 & 3 & 1 & 12 & 33 & 33.5 & 33.3 & 33.3 & 7.15 & 46.53 & 0 \\
\hline 7 & 3 & 2 & 12.1 & 33.5 & 33.7 & 33.8 & 33.7 & 7.25 & 46.44 & 0 \\
\hline 7 & 3 & 3 & 12.5 & 35.2 & 35.3 & 35.2 & 35.2 & 7.65 & 46.06 & 0 \\
\hline 7 & 3 & 4 & 12.3 & 33.3 & 33 & 33.2 & 33.2 & 7.45 & 44.52 & 0 \\
\hline 7 & 3 & 5 & 12.1 & 31.9 & 32.3 & 32.2 & 32.1 & 7.25 & 44.32 & 0 \\
\hline 7 & 4 & 1 & 11.9 & 29 & 29.9 & 30.4 & 29.8 & 7.05 & 42.22 & 0 \\
\hline 7 & 4 & 2 & 11.9 & 27.2 & 27.1 & 27 & 27.1 & 7.05 & 38.44 & 0 \\
\hline 7 & 4 & 3 & 11.5 & 24.1 & 24.3 & 24.1 & 24.2 & 6.65 & 36.34 & 0 \\
\hline 7 & 4 & 4 & 12.2 & 25.5 & 25.7 & 25.7 & 25.6 & 7.35 & 34.88 & 0 \\
\hline 7 & 4 & 5 & 12.3 & 25.7 & 25.8 & 25.7 & 25.7 & 7.45 & 34.54 & 0 \\
\hline 7 & 5 & 1 & 11.5 & 45.8 & 44.6 & 44.4 & 44.9 & 6.65 & 67.57 & 0 \\
\hline 7 & 5 & 2 & 12.8 & 54.9 & 55.2 & 55 & 55.0 & 7.95 & 69.22 & 0 \\
\hline 7 & 5 & 3 & 13.1 & 52.6 & 52.7 & 52.6 & 52.6 & 8.25 & 63.80 & 0 \\
\hline 7 & 5 & 4 & 12 & 47.6 & 47.1 & 47 & 47.2 & 7.15 & 66.06 & 0 \\
\hline 7 & 5 & 5 & 13.3 & 58.1 & 58 & 57.7 & 57.9 & 8.45 & 68.56 & 0 \\
\hline 7 & 6 & 1 & 12.4 & 36.8 & 37.3 & 37 & 37.0 & 7.55 & 49.05 & 0 \\
\hline 7 & 6 & 2 & 12.6 & 43.4 & 43.5 & 43 & 43.3 & 7.75 & 55.87 & 0 \\
\hline 7 & 6 & 3 & 11.6 & 38.7 & 38.1 & 38 & 38.3 & 6.75 & 56.69 & 0 \\
\hline 7 & 6 & 4 & 12.6 & 47.8 & 47.9 & 47.3 & 47.7 & 7.75 & 61.51 & 0 \\
\hline 7 & 6 & 5 & 12.7 & 45.7 & 45.6 & 46.8 & 46.0 & 7.85 & 58.64 & 0 \\
\hline 9 & 2 & 1 & 12.4 & 35.3 & 35.4 & 35.6 & 35.4 & 7.55 & 46.93 & 0 \\
\hline 9 & 2 & 2 & 12.4 & 35.1 & 35.3 & 35.1 & 35.2 & 7.55 & 46.58 & 0 \\
\hline 9 & 2 & 3 & 12.2 & 33.4 & 33.5 & 33.5 & 33.5 & 7.35 & 45.53 & 0 \\
\hline 9 & 2 & 4 & 12.7 & 35 & 35.4 & 34.9 & 35.1 & 7.85 & 44.71 & 0 \\
\hline 9 & 2 & 5 & 12.5 & 33.5 & 33 & 33.6 & 33.4 & 7.65 & 43.62 & 0 \\
\hline
\end{tabular}


Table A-3. continued...

\begin{tabular}{|c|c|c|c|c|c|c|c|c|c|c|}
\hline Transect & Shovel Test & Level & Weight (g) & Read 1 & Read 2 & Read 3 & Average & Correct wt. & MSS Value & On Site \\
\hline 9 & 3 & 1 & 12.3 & 37.6 & 37.7 & 37.5 & 37.6 & 7.45 & 50.47 & 0 \\
\hline 9 & 3 & 2 & 12.5 & 36.6 & 36.1 & 36.3 & 36.3 & 7.65 & 47.49 & 0 \\
\hline 9 & 3 & 3 & 12.3 & 37.1 & 37.3 & 36.8 & 37.1 & 7.45 & 49.75 & 0 \\
\hline 9 & 3 & 4 & 12.6 & 36.3 & 35.8 & 36.2 & 36.1 & 7.75 & 46.58 & 0 \\
\hline 9 & 3 & 5 & 12.6 & 34.9 & 35.2 & 24.7 & 31.6 & 7.75 & 40.77 & 0 \\
\hline 9 & 4 & 1 & 12.6 & 45.9 & 44.6 & 45 & 45.2 & 7.75 & 58.28 & 0 \\
\hline 9 & 4 & 2 & 12.7 & 44.5 & 44.6 & 44.5 & 44.5 & 7.85 & 56.73 & 0 \\
\hline 9 & 4 & 3 & 12.2 & 42.6 & 42.7 & 42.7 & 42.7 & 7.35 & 58.05 & 0 \\
\hline 9 & 4 & 4 & 12.7 & 45.5 & 45.2 & 45.5 & 45.4 & 7.85 & 57.83 & 0 \\
\hline 9 & 4 & 5 & 12.6 & 42.9 & 42.8 & 42.7 & 42.8 & 7.75 & 55.23 & 0 \\
\hline 9 & 5 & 1 & 12.4 & 41.7 & 41.6 & 41.7 & 41.7 & 7.55 & 55.19 & 1 \\
\hline 9 & 5 & 2 & 12.5 & 45.3 & 45 & 45.3 & 45.3 & 7.65 & 59.22 & 1 \\
\hline 9 & 5 & 3 & 12 & 41 & 41.4 & 41.4 & 41.3 & 7.15 & 57.72 & 1 \\
\hline 9 & 5 & 4 & 11.3 & 33.3 & 33.2 & 33.3 & 33.3 & 6.45 & 51.58 & 1 \\
\hline 9 & 5 & 5 & 11.8 & 35.4 & 35.2 & 35.1 & 35.2 & 6.95 & 50.70 & 1 \\
\hline 9 & 6 & 1 & 10.8 & 23.8 & 23.6 & 23.5 & 23.6 & 5.95 & 39.72 & 1 \\
\hline 9 & 6 & 2 & 11.3 & 26.2 & 26.1 & 26.1 & 26.1 & 6.45 & 40.52 & 1 \\
\hline 9 & 6 & 3 & 11.1 & 26.9 & 26.1 & 26.2 & 26.4 & 6.25 & 42.24 & 1 \\
\hline 9 & 6 & 4 & 11.3 & 33.5 & 33.2 & 33.4 & 33.4 & 6.45 & 51.73 & 1 \\
\hline 9 & 6 & 5 & 11.8 & 34.3 & 34 & 34 & 34.1 & 6.95 & 49.06 & 1 \\
\hline 11 & 2 & 1 & 12 & 36.2 & 36.1 & 36 & 36.1 & 7.15 & 50.49 & 0 \\
\hline 11 & 2 & 2 & 12.1 & 44.9 & 45 & 44.6 & 44.8 & 7.25 & 61.84 & 0 \\
\hline 11 & 2 & 3 & 12.8 & 45.4 & 45.5 & 45.1 & 45.3 & 7.95 & 57.02 & 0 \\
\hline 11 & 2 & 4 & 12.7 & 43.6 & 43.7 & 43.5 & 43.6 & 7.85 & 55.54 & 0 \\
\hline 11 & 2 & 5 & 12 & 39.8 & 39.7 & 39.8 & 39.8 & 7.15 & 55.62 & 0 \\
\hline 11 & 3 & 1 & 12.1 & 38.7 & 38.4 & 38.5 & 38.5 & 7.25 & 53.15 & 0 \\
\hline 11 & 3 & 2 & 12.3 & 41.1 & 40.9 & 41.2 & 41.1 & 7.45 & 55.12 & 0 \\
\hline 11 & 3 & 3 & 12.5 & 41.4 & 41.3 & 41 & 41.2 & 7.65 & 53.90 & 0 \\
\hline 11 & 3 & 4 & 12.4 & 42.4 & 42.5 & 42.3 & 42.4 & 7.55 & 56.16 & 0 \\
\hline 11 & 3 & 5 & 12.6 & 40.4 & 40.6 & 40.1 & 40.4 & 7.75 & 52.09 & 0 \\
\hline 11 & 4 & 1 & 12.5 & 40.2 & 39.9 & 40.2 & 40.1 & 7.65 & 52.42 & 1 \\
\hline 11 & 4 & 2 & 12.1 & 43.2 & 43.4 & 43.5 & 43.4 & 7.25 & 59.82 & 1 \\
\hline 11 & 4 & 3 & 12.2 & 39.8 & 39.8 & 40.1 & 39.9 & 7.35 & 54.29 & 1 \\
\hline 11 & 4 & 4 & 12.2 & 39 & 39 & 39.4 & 39.1 & 7.35 & 53.24 & 1 \\
\hline 11 & 4 & 5 & 12.1 & 43.1 & 43.7 & 43.7 & 43.5 & 7.25 & 60.00 & 1 \\
\hline 11 & 5 & 1 & 12.3 & 39.3 & 39 & 39.1 & 39.1 & 7.45 & 52.53 & 1 \\
\hline 11 & 5 & 2 & 12.1 & 41.3 & 41.6 & 41.3 & 41.4 & 7.25 & 57.10 & 1 \\
\hline 11 & 5 & 3 & 12.4 & 40.3 & 39.9 & 40.2 & 40.1 & 7.55 & 53.16 & 1 \\
\hline 11 & 5 & 4 & 12.1 & 40.3 & 40.1 & 40.3 & 40.2 & 7.25 & 55.49 & 1 \\
\hline 11 & 5 & 5 & 12 & 39.2 & 39.8 & 39.2 & 39.4 & 7.15 & 55.10 & 1 \\
\hline 11 & 6 & 1 & 12.2 & 30.2 & 30.5 & 30.3 & 30.3 & 7.35 & 41.27 & 0 \\
\hline 11 & 6 & 2 & 12.6 & 38 & 38.4 & 38.9 & 38.4 & 7.75 & 49.59 & 0 \\
\hline 11 & 6 & 3 & 12 & 31 & 31.3 & 31 & 31.1 & 7.15 & 43.50 & 0 \\
\hline 11 & 6 & 4 & 12.8 & 35.9 & 35.3 & 35.9 & 35.7 & 7.95 & 44.91 & 0 \\
\hline 11 & 6 & 5 & 12.2 & 30.2 & 29.8 & 30.4 & 30.1 & 7.35 & 41.00 & 0 \\
\hline 13 & 2 & 1 & 12 & 35 & 35.2 & 35 & 35.1 & 7.15 & 49.04 & 0 \\
\hline 13 & 2 & 2 & 12.1 & 39.5 & 39.9 & 39.9 & 39.8 & 7.25 & 54.85 & 0 \\
\hline
\end{tabular}


Table A-3. continued...

\begin{tabular}{|c|c|c|c|c|c|c|c|c|c|c|}
\hline Transect & Shovel Test & Level & Weight (g) & Read 1 & Read 2 & Read 3 & Average & Correct wt. & MSS Value & On Site \\
\hline 13 & 2 & 3 & 12.4 & 41.8 & 41.3 & 41.5 & 41.5 & 7.55 & 55.01 & 0 \\
\hline 13 & 2 & 4 & 12.6 & 42.9 & 42.8 & 42.7 & 42.8 & 7.75 & 55.23 & 0 \\
\hline 13 & 2 & 5 & 12.6 & 42.5 & 42.4 & 42.3 & 42.4 & 7.75 & 54.71 & 0 \\
\hline 13 & 3 & 1 & 12.4 & 26.2 & 26.1 & 26.1 & 26.1 & 7.55 & 34.61 & 0 \\
\hline 13 & 3 & 2 & 12.2 & 25.4 & 25.5 & 25.2 & 25.4 & 7.35 & 34.51 & 0 \\
\hline 13 & 3 & 3 & 12.4 & 17.8 & 18.1 & 18 & 18.0 & 7.55 & 23.80 & 0 \\
\hline 13 & 3 & 4 & 12.2 & 17.5 & 17.5 & 17.4 & 17.5 & 7.35 & 23.76 & 0 \\
\hline 13 & 3 & 5 & 12 & 14.7 & 14.3 & 14.7 & 14.6 & 7.15 & 20.37 & 0 \\
\hline 13 & 4 & 1 & 12.4 & 29.6 & 29.2 & 29.4 & 29.4 & 7.55 & 38.94 & 0 \\
\hline 13 & 4 & 2 & 12 & 29.4 & 29.5 & 29.4 & 29.4 & 7.15 & 41.17 & 0 \\
\hline 13 & 4 & 3 & 12.6 & 31.3 & 31.8 & 31.6 & 31.6 & 7.75 & 40.73 & 0 \\
\hline 13 & 4 & 4 & 12.3 & 28.4 & 28 & 28.2 & 28.2 & 7.45 & 37.85 & 0 \\
\hline 13 & 4 & 5 & 12.4 & 30.1 & 30.4 & 29.9 & 30.1 & 7.55 & 39.91 & 0 \\
\hline 13 & 5 & 1 & 12.6 & 28.4 & 28 & 28.1 & 28.2 & 7.75 & 36.34 & 0 \\
\hline 13 & 5 & 2 & 12.1 & 28.9 & 28.8 & 28.7 & 28.8 & 7.25 & 39.72 & 0 \\
\hline 13 & 5 & 3 & 12.5 & 29.3 & 29 & 29.2 & 29.2 & 7.65 & 38.13 & 0 \\
\hline 13 & 5 & 4 & 12.4 & 22.7 & 22.8 & 22.6 & 22.7 & 7.55 & 30.07 & 0 \\
\hline 13 & 5 & 5 & 12.1 & 20.3 & 20.1 & 19.9 & 20.1 & 7.25 & 27.72 & 0 \\
\hline 13 & 6 & 1 & 12.1 & 20.1 & 20.5 & 20 & 20.2 & 7.25 & 27.86 & 0 \\
\hline 13 & 6 & 2 & 12.1 & 22.4 & 22.3 & 22 & 22.2 & 7.25 & 30.67 & 0 \\
\hline 13 & 6 & 3 & 12.2 & 29.3 & 29.2 & 29 & 29.2 & 7.35 & 39.68 & 0 \\
\hline 13 & 6 & 4 & 12 & 28.4 & 28.7 & 28.9 & 28.7 & 7.15 & 40.09 & 0 \\
\hline 13 & 6 & 5 & 12.1 & 25.8 & 25.7 & 25.8 & 25.8 & 7.25 & 35.54 & 0 \\
\hline 15 & 2 & 1 & 12.5 & 23.9 & 24.4 & 24.1 & 24.1 & 7.65 & 31.55 & 0 \\
\hline 15 & 2 & 2 & 12.6 & 26.4 & 26.5 & 26.5 & 26.5 & 7.75 & 34.15 & 0 \\
\hline 15 & 2 & 3 & 12.5 & 24.3 & 24.2 & 24 & 24.2 & 7.65 & 31.59 & 0 \\
\hline 15 & 2 & 4 & 12.6 & 22.8 & 22.6 & 22.8 & 22.7 & 7.75 & 29.33 & 0 \\
\hline 15 & 2 & 5 & 12.6 & 19.5 & 19.8 & 19.6 & 19.6 & 7.75 & 25.33 & 0 \\
\hline 15 & 3 & 1 & 12.3 & 28.5 & 28.2 & 28.6 & 28.4 & 7.45 & 38.17 & 0 \\
\hline 15 & 3 & 2 & 12.1 & 25.4 & 25.6 & 25.4 & 25.5 & 7.25 & 35.13 & 0 \\
\hline 15 & 3 & 3 & 12.3 & 20 & 20.4 & 20 & 20.1 & 7.45 & 27.02 & 0 \\
\hline 15 & 3 & 4 & 12.3 & 18.4 & 18.8 & 18.4 & 18.5 & 7.45 & 24.88 & 0 \\
\hline 15 & 3 & 5 & 12 & 17.2 & 17.1 & 17.3 & 17.2 & 7.15 & 24.06 & 0 \\
\hline 15 & 4 & 1 & 12.6 & 26.9 & 26.7 & 26.9 & 26.8 & 7.75 & 34.62 & 0 \\
\hline 15 & 4 & 2 & 12.4 & 30.6 & 29.8 & 30.2 & 30.2 & 7.55 & 40.00 & 0 \\
\hline 15 & 4 & 3 & 12.6 & 27.1 & 27.1 & 27.5 & 27.2 & 7.75 & 35.14 & 0 \\
\hline 15 & 4 & 4 & 12.4 & 30.5 & 30.3 & 30 & 30.3 & 7.55 & 40.09 & 0 \\
\hline 15 & 4 & 5 & 12.6 & 50.5 & 51 & 50.4 & 50.6 & 7.75 & 65.33 & 0 \\
\hline 15 & 5 & 1 & 12.6 & 25.5 & 25.8 & 26 & 25.8 & 7.75 & 33.25 & 0 \\
\hline 15 & 5 & 2 & 12.6 & 30.3 & 30.3 & 30.6 & 30.4 & 7.75 & 39.23 & 0 \\
\hline 15 & 5 & 3 & 12.6 & 30 & 30.5 & 30.3 & 30.3 & 7.75 & 39.05 & 0 \\
\hline 15 & 5 & 4 & 12.4 & 33.1 & 31.6 & 31.7 & 32.1 & 7.55 & 42.56 & 0 \\
\hline 15 & 5 & 5 & 12.5 & 33.1 & 32.9 & 32.8 & 32.9 & 7.65 & 43.05 & 0 \\
\hline 15 & 6 & 1 & 12.4 & 25 & 24.7 & 24.6 & 24.8 & 7.55 & 32.80 & 0 \\
\hline 15 & 6 & 2 & 12.5 & 26.8 & 26.8 & 26.7 & 26.8 & 7.65 & 34.99 & 0 \\
\hline 15 & 6 & 3 & 12.6 & 25.7 & 25.9 & 25.7 & 25.8 & 7.75 & 33.25 & 0 \\
\hline 15 & 6 & 4 & 12.5 & 24.9 & 24.7 & 24.7 & 24.8 & 7.65 & 32.37 & 0 \\
\hline
\end{tabular}


Table A-3. continued...

\begin{tabular}{|c|c|c|c|c|c|c|c|c|c|c|}
\hline Transect & Shovel Test & Level & Weight (g) & Read 1 & Read 2 & Read 3 & Average & Correct wt. & MSS Value & On Site \\
\hline 15 & 6 & 5 & 12.4 & 24.1 & 25.6 & 25.4 & 25.0 & 7.55 & 33.16 & 0 \\
\hline 15 & 6 & 6 & 12.5 & 25.2 & 25 & 24.9 & 25.0 & 7.65 & 32.72 & 0 \\
\hline 15 & 7 & 1 & 12.5 & 25.2 & 25.1 & 25.5 & 25.3 & 7.65 & 33.03 & 0 \\
\hline 15 & 7 & 2 & 12.6 & 22.2 & 22.5 & 22.3 & 22.3 & 7.75 & 28.82 & 0 \\
\hline 15 & 7 & 3 & 12.6 & 17.8 & 17.7 & 17.8 & 17.8 & 7.75 & 22.92 & 0 \\
\hline 15 & 7 & 4 & 12.5 & 16.5 & 16.8 & 16.3 & 16.5 & 7.65 & 21.61 & 0 \\
\hline 15 & 7 & 5 & 12.6 & 17 & 16.9 & 16.5 & 16.8 & 7.75 & 21.68 & 0 \\
\hline 15 & 8 & 1 & 12.5 & 21.1 & 21 & 20.9 & 21.0 & 7.65 & 27.45 & 0 \\
\hline 15 & 8 & 2 & 12.6 & 22.2 & 22.4 & 22.8 & 22.5 & 7.75 & 28.99 & 0 \\
\hline 15 & 8 & 3 & 12.6 & 19.2 & 18.6 & 19.1 & 19.0 & 7.75 & 24.47 & 0 \\
\hline 15 & 8 & 4 & 12.6 & 20.5 & 20.6 & 20.3 & 20.5 & 7.75 & 26.41 & 0 \\
\hline 15 & 8 & 5 & 12.4 & 22.9 & 22.7 & 22.8 & 22.8 & 7.55 & 30.20 & 0 \\
\hline 17 & 2 & 1 & 12.2 & 31.1 & 30.8 & 30.8 & 30.9 & 7.35 & 42.04 & 0 \\
\hline 17 & 2 & 2 & 12.3 & 30.3 & 30.5 & 30.2 & 30.3 & 7.45 & 40.72 & 0 \\
\hline 17 & 2 & 3 & 12.6 & 29.7 & 29.7 & 29.5 & 29.6 & 7.75 & 38.24 & 0 \\
\hline 17 & 2 & 4 & 12.1 & 24.8 & 25 & 24.9 & 24.9 & 7.25 & 34.34 & 0 \\
\hline 17 & 2 & 5 & 12 & 19 & 18.9 & 19.1 & 19.0 & 7.15 & 26.57 & 0 \\
\hline 17 & 3 & 1 & 12.2 & 21.9 & 22.1 & 21.6 & 21.9 & 7.35 & 29.75 & 0 \\
\hline 17 & 3 & 2 & 12.3 & 22.7 & 22.6 & 22.2 & 22.5 & 7.45 & 30.20 & 0 \\
\hline 17 & 3 & 3 & 12.9 & 18 & 17.9 & 18.1 & 18.0 & 8.05 & 22.36 & 0 \\
\hline 17 & 3 & 4 & 12.5 & 21.2 & 20.9 & 21.4 & 21.2 & 7.65 & 27.67 & 0 \\
\hline 17 & 3 & 5 & 12.3 & 17.1 & 17 & 17.2 & 17.1 & 7.45 & 22.95 & 0 \\
\hline 17 & 4 & 1 & 12.4 & 24.1 & 24 & 24.7 & 24.3 & 7.55 & 32.14 & 0 \\
\hline 17 & 4 & 2 & 12.3 & 23.1 & 23 & 23 & 23.0 & 7.45 & 30.92 & 0 \\
\hline 17 & 4 & 3 & 12.7 & 29.9 & 23 & 23 & 25.3 & 7.85 & 32.23 & 0 \\
\hline 17 & 4 & 4 & 11.8 & 21.4 & 21.4 & 21.4 & 21.4 & 6.95 & 30.79 & 0 \\
\hline 17 & 4 & 5 & 12.5 & 18.4 & 18.4 & 18.5 & 18.4 & 7.65 & 24.10 & 0 \\
\hline 17 & 5 & 1 & 12 & 21.8 & 22 & 22.2 & 22.0 & 7.15 & 30.77 & 0 \\
\hline 17 & 5 & 2 & 12.5 & 17.9 & 18.1 & 17.4 & 17.8 & 7.65 & 23.27 & 0 \\
\hline 17 & 5 & 3 & 12.1 & 15.3 & 15.5 & 15.8 & 15.5 & 7.25 & 21.43 & 0 \\
\hline 17 & 5 & 4 & 11.9 & 13.5 & 13.2 & 13.5 & 13.4 & 7.05 & 19.01 & 0 \\
\hline 17 & 5 & 5 & 12.1 & 16.3 & 16.5 & 16 & 16.3 & 7.25 & 22.44 & 0 \\
\hline 17 & 6 & 1 & 12 & 10.4 & 10.9 & 10.4 & 10.6 & 7.15 & 14.78 & 0 \\
\hline 17 & 6 & 2 & 12.4 & 13.1 & 13.1 & 12.6 & 12.9 & 7.55 & 17.13 & 0 \\
\hline 17 & 6 & 3 & 12 & 47.2 & 47.8 & 47.1 & 47.4 & 7.15 & 66.25 & 0 \\
\hline 17 & 6 & 4 & 12 & 14 & 14.3 & 14.2 & 14.2 & 7.15 & 19.81 & 0 \\
\hline 17 & 6 & 5 & 12.8 & 14.1 & 14.4 & 14.4 & 14.3 & 7.95 & 17.99 & 0 \\
\hline 17 & 7 & 1 & 12.5 & 13.6 & 13.4 & 13.6 & 13.5 & 7.65 & 17.69 & 0 \\
\hline 17 & 7 & 2 & 12.5 & 15.6 & 15.3 & 15 & 15.3 & 7.65 & 20.00 & 0 \\
\hline 17 & 7 & 3 & 12.5 & 16 & 16 & 16.6 & 16.2 & 7.65 & 21.18 & 0 \\
\hline 17 & 7 & 4 & 12.4 & 15.7 & 15.2 & 15.3 & 15.4 & 7.55 & 20.40 & 0 \\
\hline 17 & 7 & 5 & 12.4 & 14 & 14 & 13.9 & 14.0 & 7.55 & 18.50 & 0 \\
\hline 17 & 8 & 1 & 12.6 & 18.8 & 18.5 & 18.1 & 18.5 & 7.75 & 23.83 & 0 \\
\hline 17 & 8 & 2 & 12.6 & 16.1 & 15.8 & 15.7 & 15.9 & 7.75 & 20.47 & 0 \\
\hline 17 & 8 & 3 & 12.5 & 15.2 & 14.9 & 15.6 & 15.2 & 7.65 & 19.91 & 0 \\
\hline 17 & 8 & 4 & 12.4 & 15 & 15.2 & 15.1 & 15.1 & 7.55 & 20.00 & 0 \\
\hline 17 & 8 & 5 & 12 & 14.1 & 14 & 14 & 14.0 & 7.15 & 19.63 & 0 \\
\hline
\end{tabular}


Table A-3. continued...

\begin{tabular}{|c|c|c|c|c|c|c|c|c|c|c|}
\hline Transect & Shovel Test & Level & Weight $(\mathrm{g})$ & Read 1 & Read 2 & Read 3 & Average & Correct wt. & MSS Value & On Site \\
\hline 19 & 2 & 1 & 12.4 & 18.2 & 18.1 & 18 & 18.1 & 7.55 & 23.97 & 0 \\
\hline 19 & 2 & 2 & 12.5 & 17.3 & 17.5 & 17.5 & 17.4 & 7.65 & 22.79 & 0 \\
\hline 19 & 2 & 3 & 12.4 & 16.2 & 16.4 & 16 & 16.2 & 7.55 & 21.46 & 0 \\
\hline 19 & 2 & 4 & 12.5 & 16 & 16.3 & 16.2 & 16.2 & 7.65 & 21.13 & 0 \\
\hline 19 & 2 & 5 & 12.5 & 16 & 15.8 & 16.1 & 16.0 & 7.65 & 20.87 & 0 \\
\hline 19 & 3 & 1 & 12.4 & 18.4 & 18.2 & 18.5 & 18.4 & 7.55 & 24.33 & 0 \\
\hline 19 & 3 & 2 & 12.6 & 16.4 & 16.6 & 16.3 & 16.4 & 7.75 & 21.20 & 0 \\
\hline 19 & 3 & 3 & 12.6 & 32.4 & 32.7 & 32.5 & 32.5 & 7.75 & 41.98 & 0 \\
\hline 19 & 3 & 4 & 12.5 & 15.4 & 15.2 & 15.3 & 15.3 & 7.65 & 20.00 & 0 \\
\hline 19 & 3 & 5 & 12.6 & 14.9 & 14.5 & 15.2 & 14.9 & 7.75 & 19.18 & 0 \\
\hline 19 & 4 & 1 & 12.5 & 24.3 & 23.8 & 24.1 & 24.1 & 7.65 & 31.46 & 0 \\
\hline 19 & 4 & 2 & 12.5 & 26.1 & 25.6 & 26 & 25.9 & 7.65 & 33.86 & 0 \\
\hline 19 & 4 & 3 & 12.5 & 23.8 & 23.9 & 23.5 & 23.7 & 7.65 & 31.02 & 0 \\
\hline 19 & 4 & 4 & 12.6 & 23.1 & 23.1 & 22.9 & 23.0 & 7.75 & 29.72 & 0 \\
\hline 19 & 4 & 5 & 12.6 & 21.3 & 21.2 & & 14.2 & 7.75 & 18.28 & 0 \\
\hline 19 & 5 & 1 & 12.4 & 18.9 & 19.1 & 18.8 & 18.9 & 7.55 & 25.08 & 0 \\
\hline 19 & 5 & 2 & 12.6 & 17.8 & 18 & 17.6 & 17.8 & 7.75 & 22.97 & 0 \\
\hline 19 & 5 & 3 & 12.5 & 19.7 & 20 & 20 & 19.9 & 7.65 & 26.01 & 0 \\
\hline 19 & 5 & 4 & 12.5 & 16.6 & 16.7 & 16.6 & 16.6 & 7.65 & 21.74 & 0 \\
\hline 19 & 5 & 5 & 12.5 & 16.2 & 15.8 & 16 & 16.0 & 7.65 & 20.92 & 0 \\
\hline 19 & 6 & 1 & 12.4 & 17.1 & 17.5 & 17.5 & 17.4 & 7.55 & 23.00 & 0 \\
\hline 19 & 6 & 2 & 12.6 & 17.5 & 17.2 & 17.1 & 17.3 & 7.75 & 22.28 & 0 \\
\hline 19 & 6 & 3 & 12.5 & 14.9 & 14.8 & 14.7 & 14.8 & 7.65 & 19.35 & 0 \\
\hline 19 & 6 & 4 & 12.5 & 14.1 & 13.8 & 13.8 & 13.9 & 7.65 & 18.17 & 0 \\
\hline 19 & 6 & 5 & 12.6 & 12.2 & 12.2 & 12.4 & 12.3 & 7.75 & 15.83 & 0 \\
\hline 19 & 7 & 1 & 12.6 & 26.2 & 26 & 26.1 & 26.1 & 7.75 & 33.68 & 0 \\
\hline 19 & 7 & 2 & 12.6 & 24.4 & 24.4 & 24.6 & 24.5 & 7.75 & 31.57 & 0 \\
\hline 19 & 7 & 3 & 12.5 & 21.8 & 21.3 & 21.2 & 21.4 & 7.65 & 28.02 & 0 \\
\hline 19 & 7 & 4 & 12.4 & 19.2 & 19 & 18.9 & 19.0 & 7.55 & 25.21 & 0 \\
\hline 19 & 7 & 5 & 12.4 & 18.8 & 19 & 18.8 & 18.9 & 7.55 & 24.99 & 0 \\
\hline 19 & 8 & 1 & 12.4 & 18.5 & 18.3 & 18.7 & 18.5 & 7.55 & 24.50 & 0 \\
\hline 19 & 8 & 2 & 12.6 & 19.4 & 19.3 & 19.8 & 19.5 & 7.75 & 25.16 & 0 \\
\hline 19 & 8 & 3 & 12.5 & 17 & 17.2 & 17.1 & 17.1 & 7.65 & 22.35 & 0 \\
\hline 19 & 8 & 4 & 12.5 & 21.1 & 20.7 & 20.3 & 20.7 & 7.65 & 27.06 & 0 \\
\hline 19 & 8 & 5 & 12.6 & 17.4 & 17.4 & 17.7 & 17.5 & 7.75 & 22.58 & 0 \\
\hline 21 & 2 & 1 & 12.5 & 21.1 & 21.3 & 21.3 & 21.2 & 7.65 & 27.76 & 0 \\
\hline 21 & 2 & 2 & 12.4 & 21.6 & 21.6 & 21.4 & 21.5 & 7.55 & 28.52 & 0 \\
\hline 21 & 2 & 3 & 12.4 & 18.1 & 18.1 & 18.1 & 18.1 & 7.55 & 23.97 & 0 \\
\hline 21 & 2 & 4 & 12.4 & 16.1 & 16.7 & 16.2 & 16.3 & 7.55 & 21.63 & 0 \\
\hline 21 & 2 & 5 & 12.4 & 15.2 & 15 & 14.8 & 15.0 & 7.55 & 19.87 & 0 \\
\hline 21 & 3 & 1 & 12.5 & 20.8 & 20.7 & 20.9 & 20.8 & 7.65 & 27.19 & 0 \\
\hline 21 & 3 & 2 & 12.6 & 20.7 & 20.7 & 20.9 & 20.8 & 7.75 & 26.80 & 0 \\
\hline 21 & 3 & 3 & 12.5 & 23.9 & 24 & 24.1 & 24.0 & 7.65 & 31.37 & 0 \\
\hline 21 & 3 & 4 & 12.6 & 13.6 & 13 & 13.3 & 13.3 & 7.75 & 17.16 & 0 \\
\hline 21 & 3 & 5 & 12.6 & 12.9 & 12.6 & 12.8 & 12.8 & 7.75 & 16.47 & 0 \\
\hline 21 & 4 & 1 & 12.6 & 27.6 & 27.3 & 27.6 & 27.5 & 7.75 & 35.48 & 0 \\
\hline 21 & 4 & 2 & 12.4 & 29.1 & 29.4 & 29.6 & 29.4 & 7.55 & 38.90 & 0 \\
\hline
\end{tabular}


Table A-3. continued...

\begin{tabular}{|c|c|c|c|c|c|c|c|c|c|c|}
\hline Transect & Shovel Test & Level & Weight (g) & Read 1 & Read 2 & Read 3 & Average & Correct wt. & MSS Value & On Site \\
\hline 21 & 4 & 3 & 12.5 & 33.7 & 33.3 & 33.3 & 33.4 & 7.65 & 43.70 & 0 \\
\hline 21 & 4 & 4 & 12.5 & 29.2 & 28.9 & 28.9 & 29.0 & 7.65 & 37.91 & 0 \\
\hline 21 & 4 & 5 & 12.5 & 45.6 & 45.4 & 45.3 & 45.4 & 7.65 & 59.39 & 0 \\
\hline 21 & 5 & 1 & 12.6 & 28.8 & 28.7 & 28.2 & 28.6 & 7.75 & 36.86 & 0 \\
\hline 21 & 5 & 2 & 12.5 & 40 & 39.7 & 39.9 & 39.9 & 7.65 & 52.11 & 0 \\
\hline 21 & 5 & 3 & 12.5 & 30.5 & 30.9 & 31 & 30.8 & 7.65 & 40.26 & 0 \\
\hline 21 & 5 & 4 & 12.6 & 31 & 31.2 & 30.8 & 31.0 & 7.75 & 40.00 & 0 \\
\hline 21 & 5 & 5 & 12.4 & 29.7 & 29.3 & 29.2 & 29.4 & 7.55 & 38.94 & 0 \\
\hline 21 & 6 & 1 & 12.6 & 24.6 & 24.6 & 24.5 & 24.6 & 7.75 & 31.70 & 0 \\
\hline 21 & 6 & 2 & 12.4 & 34.7 & 34.7 & 34.9 & 34.8 & 7.55 & 46.05 & 0 \\
\hline 21 & 6 & 3 & 12.5 & 27.8 & 28.1 & 28 & 28.0 & 7.65 & 36.56 & 0 \\
\hline 21 & 6 & 4 & 12.4 & 24.7 & 24.5 & 24.2 & 24.5 & 7.55 & 32.41 & 0 \\
\hline 21 & 6 & 5 & 12.6 & 18.7 & 18.9 & 19 & 18.9 & 7.75 & 24.34 & 0 \\
\hline 21 & 7 & 1 & 12.5 & 26.7 & 26.8 & 26.6 & 26.7 & 7.65 & 34.90 & 0 \\
\hline 21 & 7 & 2 & 12.5 & 23.4 & 23.5 & 23.2 & 23.4 & 7.65 & 30.54 & 0 \\
\hline 21 & 7 & 3 & 12.4 & 19.5 & 19.1 & 19.8 & 19.5 & 7.55 & 25.78 & 0 \\
\hline 21 & 7 & 4 & 12.6 & 19.3 & 19.3 & 19.4 & 19.3 & 7.75 & 24.95 & 0 \\
\hline 21 & 7 & 5 & 12.5 & 20.3 & 20.5 & 20.4 & 20.4 & 7.65 & 26.67 & 0 \\
\hline 21 & 8 & 1 & 12.5 & 18.5 & 18.8 & 18.7 & 18.7 & 7.65 & 24.40 & 0 \\
\hline 21 & 8 & 2 & 12.4 & 25.6 & 25.6 & 25.9 & 25.7 & 7.55 & 34.04 & 0 \\
\hline 21 & 8 & 3 & 12.4 & 27.2 & 27.2 & 26.9 & 27.1 & 7.55 & 35.89 & 0 \\
\hline 21 & 8 & 4 & 12.4 & 23.7 & 23.9 & 23.8 & 23.8 & 7.55 & 31.52 & 0 \\
\hline 21 & 8 & 5 & 12.5 & 16.3 & 15.8 & 15.8 & 16.0 & 7.65 & 20.87 & 0 \\
\hline 23 & 2 & 1 & 12.5 & 21.3 & 21.4 & 21.8 & 21.5 & 7.65 & 28.10 & 0 \\
\hline 23 & 2 & 2 & 12.4 & 18 & 18.4 & 18.1 & 18.2 & 7.55 & 24.06 & 0 \\
\hline 23 & 2 & 3 & 12.5 & 18.2 & 18.4 & 17.9 & 18.2 & 7.65 & 23.75 & 0 \\
\hline 23 & 2 & 4 & 12.4 & 16.9 & 17.3 & 17 & 17.1 & 7.55 & 22.60 & 0 \\
\hline 23 & 2 & 5 & 12.5 & 15.7 & 15.8 & 15.4 & 15.6 & 7.65 & 20.44 & 0 \\
\hline 23 & 3 & 1 & 12.5 & 21.2 & 21.3 & 21 & 21.2 & 7.65 & 27.67 & 0 \\
\hline 23 & 3 & 2 & 12.4 & 21.4 & 21.7 & 21.2 & 21.4 & 7.55 & 28.39 & 0 \\
\hline 23 & 3 & 3 & 12.6 & 18.8 & 19.1 & 19.2 & 19.0 & 7.75 & 24.56 & 0 \\
\hline 23 & 3 & 4 & 12.5 & 16.6 & 16.8 & 16.7 & 16.7 & 7.65 & 21.83 & 0 \\
\hline 23 & 3 & 5 & 12.5 & 15.2 & 15.4 & 15 & 15.2 & 7.65 & 19.87 & 0 \\
\hline 23 & 4 & 1 & 12.6 & 24.7 & 24.6 & 24.7 & 24.7 & 7.75 & 31.83 & 0 \\
\hline 23 & 4 & 2 & 12.6 & 24.2 & 24.1 & 24 & 24.1 & 7.75 & 31.10 & 0 \\
\hline 23 & 4 & 3 & 12.5 & 15.9 & 16 & 15.9 & 15.9 & 7.65 & 20.83 & 0 \\
\hline 23 & 4 & 4 & 12.5 & 16 & 16.1 & 15.9 & 16.0 & 7.65 & 20.92 & 0 \\
\hline 23 & 5 & 1 & 12.6 & 20.3 & 30.6 & 20.3 & 23.7 & 7.75 & 30.62 & 0 \\
\hline 23 & 5 & 2 & 12.4 & 17.6 & 17.8 & 17.6 & 17.7 & 7.55 & 23.40 & 0 \\
\hline 23 & 5 & 3 & 12.4 & 11.1 & 11 & 11.5 & 11.2 & 7.55 & 14.83 & 0 \\
\hline 23 & 5 & 4 & 12.6 & 9 & 8 & 9 & 8.7 & 7.75 & 11.18 & 0 \\
\hline 23 & 5 & 5 & 12.5 & 12.1 & 11.9 & 12 & 12.0 & 7.65 & 15.69 & 0 \\
\hline 23 & 6 & 1 & 12.5 & 24.9 & 24.8 & 24.8 & 24.8 & 7.65 & 32.46 & 0 \\
\hline 23 & 6 & 2 & 12.6 & 23.6 & 23.7 & 23.7 & 23.7 & 7.75 & 30.54 & 0 \\
\hline 23 & 6 & 3 & 12.5 & 20.7 & 20.7 & 20.2 & 20.5 & 7.65 & 26.84 & 0 \\
\hline 23 & 6 & 4 & 12.4 & 19.5 & 19.1 & 19.8 & 19.5 & 7.55 & 25.78 & 0 \\
\hline 23 & 6 & 5 & 12.4 & 14.9 & 14.7 & 15.1 & 14.9 & 7.55 & 19.74 & 0 \\
\hline
\end{tabular}


Table A-3. continued...

\begin{tabular}{|c|c|c|c|c|c|c|c|c|c|c|}
\hline Transect & Shovel Test & Level & Weight $(\mathrm{g})$ & Read 1 & Read 2 & Read 3 & Average & Correct wt. & MSS Value & On Site \\
\hline 23 & 7 & 1 & 12.5 & 27.5 & 27.7 & 27.8 & 27.7 & 7.65 & 36.17 & 0 \\
\hline 23 & 7 & 2 & 12.4 & 33.6 & 33.1 & 33.6 & 33.4 & 7.55 & 44.28 & 0 \\
\hline 23 & 7 & 3 & 12.5 & 26.1 & 26.3 & 26.2 & 26.2 & 7.65 & 34.25 & 0 \\
\hline 23 & 7 & 4 & 12.6 & 24 & 24.3 & 24.3 & 24.2 & 7.75 & 31.23 & 0 \\
\hline 23 & 7 & 5 & 12.4 & 30.4 & 30.8 & 30.2 & 30.5 & 7.55 & 40.35 & 0 \\
\hline 23 & 8 & 1 & 12.4 & 20.3 & 20.1 & 19.9 & 20.1 & 7.55 & 26.62 & 0 \\
\hline 23 & 8 & 2 & 12.4 & 25 & 25.1 & 24.9 & 25.0 & 7.55 & 33.11 & 0 \\
\hline 23 & 8 & 3 & 12.5 & 26 & 26.3 & 26.3 & 26.2 & 7.65 & 34.25 & 0 \\
\hline 23 & 8 & 4 & 12.5 & 25.9 & 25.6 & 25.8 & 25.8 & 7.65 & 33.68 & 0 \\
\hline 23 & 8 & 5 & 12.4 & 22.9 & 23.3 & 22.8 & 23.0 & 7.55 & 30.46 & 0 \\
\hline 23 & 9 & 1 & 12.5 & 21.1 & 21 & 19.8 & 20.6 & 7.65 & 26.97 & 0 \\
\hline 23 & 9 & 2 & 12.5 & 21.8 & 21.5 & 21.7 & 21.7 & 7.65 & 28.32 & 0 \\
\hline 23 & 9 & 3 & 12.4 & 16.9 & 16.4 & 16.6 & 16.6 & 7.55 & 22.03 & 0 \\
\hline 23 & 9 & 4 & 12.5 & 12.6 & 12.5 & 12.6 & 12.6 & 7.65 & 16.43 & 0 \\
\hline 23 & 9 & 5 & 12.56 & 11.3 & 11.3 & 11.2 & 11.3 & 7.71 & 14.61 & 0 \\
\hline 25 & 2 & 1 & 12.5 & 14.1 & 14.2 & 14.5 & 14.3 & 7.65 & 18.65 & 0 \\
\hline 25 & 2 & 2 & 12.4 & 12 & 11.9 & & 8.0 & 7.55 & 10.55 & 0 \\
\hline 25 & 2 & 3 & 12.4 & 11.2 & 11.3 & 11.3 & 11.3 & 7.55 & 14.92 & 0 \\
\hline 25 & 2 & 4 & 12.4 & 9.6 & 9.8 & 9.7 & 9.7 & 7.55 & 12.85 & 0 \\
\hline 25 & 2 & 5 & 12.6 & 9.9 & 9.7 & 10 & 9.9 & 7.75 & 12.73 & 0 \\
\hline 25 & 3 & 1 & 12.5 & 16 & 16.9 & 16.4 & 16.4 & 7.65 & 21.48 & 0 \\
\hline 25 & 3 & 2 & 12.5 & 11.6 & 11.3 & 11.1 & 11.3 & 7.65 & 14.81 & 0 \\
\hline 25 & 3 & 3 & 12.6 & 12.1 & 12.4 & 12.3 & 12.3 & 7.75 & 15.83 & 0 \\
\hline 25 & 3 & 4 & 12.5 & 11.7 & 12 & 11.8 & 11.8 & 7.65 & 15.47 & 0 \\
\hline 25 & 3 & 5 & 12.5 & 12.5 & 12.4 & 12.2 & 12.4 & 7.65 & 16.17 & 0 \\
\hline 25 & 4 & 1 & 12.6 & 47.5 & 48.4 & 48.2 & 48.0 & 7.75 & 61.98 & 0 \\
\hline 25 & 4 & 2 & 12.4 & 17.6 & 17.9 & 18.1 & 17.9 & 7.55 & 23.66 & 0 \\
\hline 25 & 4 & 3 & 12.5 & 17 & 16.9 & 16.8 & 16.9 & 7.65 & 22.09 & 0 \\
\hline 25 & 4 & 4 & 12.5 & 16.8 & 16.8 & 16.7 & 16.8 & 7.65 & 21.92 & 0 \\
\hline 25 & 4 & 5 & 12.6 & 18.8 & 18.4 & 18.9 & 18.7 & 7.75 & 24.13 & 0 \\
\hline 25 & 5 & 1 & 12.5 & 18.7 & 18.8 & 18.7 & 18.7 & 7.65 & 24.49 & 0 \\
\hline 25 & 5 & 2 & 12.4 & 19.9 & 19.6 & 19.6 & 19.7 & 7.55 & 26.09 & 0 \\
\hline 25 & 5 & 3 & 12.5 & 14.9 & 15.3 & 15 & 15.1 & 7.65 & 19.69 & 0 \\
\hline 25 & 5 & 4 & 12.4 & 14.5 & 14.4 & 14.5 & 14.5 & 7.55 & 19.16 & 0 \\
\hline 25 & 5 & 5 & 12.4 & 14 & 14.6 & 14.2 & 14.3 & 7.55 & 18.90 & 0 \\
\hline 25 & 6 & 1 & 12.5 & 20.8 & 20.5 & 20.1 & 20.5 & 7.65 & 26.75 & 0 \\
\hline 25 & 6 & 2 & 12.6 & 9.9 & 9.8 & 10.2 & 10.0 & 7.75 & 12.86 & 0 \\
\hline 25 & 6 & 3 & 12.4 & 10.3 & 9.8 & 10.5 & 10.2 & 7.55 & 13.51 & 0 \\
\hline 25 & 6 & 4 & 12.4 & 10.7 & 10.5 & 10.7 & 10.6 & 7.55 & 14.08 & 0 \\
\hline 25 & 6 & 5 & 12.5 & 11.6 & 11.1 & 11.4 & 11.4 & 7.65 & 14.86 & 0 \\
\hline 25 & 7 & 1 & 12.3 & 21.3 & 21 & 20.9 & 21.1 & 7.45 & 28.28 & 0 \\
\hline 25 & 7 & 2 & 12.5 & 23.3 & 23.1 & 23.3 & 23.2 & 7.65 & 30.37 & 0 \\
\hline 25 & 7 & 3 & 12.6 & 22.9 & 22.7 & 22.8 & 22.8 & 7.75 & 29.42 & 0 \\
\hline 25 & 7 & 4 & 12.5 & 22.4 & 22.5 & 22.5 & 22.5 & 7.65 & 29.37 & 0 \\
\hline 25 & 7 & 5 & 12.4 & 21.5 & 21.8 & 21.7 & 21.7 & 7.55 & 28.70 & 0 \\
\hline 25 & 8 & 1 & 12.5 & 17.4 & 17.4 & 17.1 & 17.3 & 7.65 & 22.61 & 0 \\
\hline 25 & 8 & 2 & 12.5 & 16.2 & 15.9 & 16.1 & 16.1 & 7.65 & 21.00 & 0 \\
\hline
\end{tabular}


Table A-3. continued...

\begin{tabular}{|c|c|c|c|c|c|c|c|c|c|c|}
\hline Transect & Shovel Test & Level & Weight $(\mathrm{g})$ & Read 1 & Read 2 & Read 3 & Average & Correct wt. & MSS Value & On Site \\
\hline 25 & 8 & 3 & 12.6 & 16.6 & 16.1 & 16.3 & 16.3 & 7.75 & 21.08 & 0 \\
\hline 25 & 8 & 4 & 12.5 & 17.6 & 17.6 & 17.1 & 17.4 & 7.65 & 22.79 & 0 \\
\hline 25 & 8 & 5 & 12.5 & 15.8 & 16.1 & 15.8 & 15.9 & 7.65 & 20.78 & 0 \\
\hline 25 & 9 & 1 & 12.5 & 21.2 & 21.8 & 21.3 & 21.4 & 7.65 & 28.02 & 0 \\
\hline 25 & 9 & 2 & 12.5 & 19.3 & 18.9 & 19.3 & 19.2 & 7.65 & 25.05 & 0 \\
\hline 25 & 9 & 3 & 12.5 & 15.3 & 15.8 & 15.2 & 15.4 & 7.65 & 20.17 & 0 \\
\hline 25 & 9 & 4 & 12.5 & 12.4 & 12.6 & 12.5 & 12.5 & 7.65 & 16.34 & 0 \\
\hline 25 & 9 & 5 & 12.4 & 12.8 & 13 & 13.1 & 13.0 & 7.55 & 17.17 & 0 \\
\hline 27 & 2 & 1 & 12.6 & 19.5 & 19.8 & 19.3 & 19.5 & 7.75 & 25.20 & 0 \\
\hline 27 & 2 & 2 & 12.6 & 21.5 & 21.3 & 21.6 & 21.5 & 7.75 & 27.70 & 0 \\
\hline 27 & 2 & 3 & 12.6 & 20.4 & 20.9 & 20.9 & 20.7 & 7.75 & 26.75 & 0 \\
\hline 27 & 2 & 4 & 12.5 & 18.4 & 18.2 & 18.4 & 18.3 & 7.65 & 23.97 & 0 \\
\hline 27 & 2 & 5 & 12.4 & 14.4 & 14.4 & 14.3 & 14.4 & 7.55 & 19.03 & 0 \\
\hline 27 & 3 & 1 & 12.5 & 22.2 & 22.6 & 22.4 & 22.4 & 7.65 & 29.28 & 0 \\
\hline 27 & 3 & 2 & 12.4 & 19.7 & 19.6 & 19.2 & 19.5 & 7.55 & 25.83 & 0 \\
\hline 27 & 3 & 3 & 12.5 & 20.5 & 20.6 & 20.5 & 20.5 & 7.65 & 26.84 & 0 \\
\hline 27 & 3 & 4 & 12.4 & 14 & 13.9 & 13.7 & 13.9 & 7.55 & 18.37 & 0 \\
\hline 27 & 3 & 5 & 12.5 & 13.2 & 13 & 13.1 & 13.1 & 7.65 & 17.12 & 0 \\
\hline 27 & 4 & 1 & 12.5 & 20.9 & 20.8 & 20.8 & 20.8 & 7.65 & 27.23 & 0 \\
\hline 27 & 4 & 2 & 12.5 & 21.4 & 21.1 & 21.1 & 21.2 & 7.65 & 27.71 & 0 \\
\hline 27 & 4 & 3 & 12.4 & 16.6 & 16.7 & 16.9 & 16.7 & 7.55 & 22.16 & 0 \\
\hline 27 & 4 & 4 & 12.4 & 16.3 & 16.1 & 16.3 & 16.2 & 7.55 & 21.50 & 0 \\
\hline 27 & 4 & 5 & 12.5 & 11.6 & 12 & 12 & 11.9 & 7.65 & 15.51 & 0 \\
\hline 27 & 5 & 1 & 12.4 & 21.7 & 21.2 & 21.4 & 21.4 & 7.55 & 28.39 & 0 \\
\hline 27 & 5 & 2 & 12.4 & 23.5 & 23.7 & 23.5 & 23.6 & 7.55 & 31.21 & 0 \\
\hline 27 & 5 & 3 & 12.4 & 21.1 & 21.4 & 21.3 & 21.3 & 7.55 & 28.17 & 0 \\
\hline 27 & 5 & 4 & 12.5 & 19.3 & 19.1 & 19.5 & 19.3 & 7.65 & 25.23 & 0 \\
\hline 27 & 5 & 5 & 12.6 & 18.6 & 18.7 & 18.1 & 18.5 & 7.75 & 23.83 & 0 \\
\hline 27 & 6 & 1 & 12.5 & 29.1 & 29.5 & 29.6 & 29.4 & 7.65 & 38.43 & 0 \\
\hline 27 & 6 & 2 & 12.4 & 47.8 & 47.3 & 47 & 47.4 & 7.55 & 62.74 & 0 \\
\hline 27 & 6 & 3 & 12.4 & 34.6 & 35 & 35.2 & 34.9 & 7.55 & 46.27 & 0 \\
\hline 27 & 6 & 4 & 12.5 & 19.6 & 19.1 & 19.6 & 19.4 & 7.65 & 25.40 & 0 \\
\hline 27 & 6 & 5 & 12.5 & 18.8 & 19 & 19.1 & 19.0 & 7.65 & 24.79 & 0 \\
\hline 27 & 7 & 1 & 12.5 & 23.4 & 23.4 & 23.9 & 23.6 & 7.65 & 30.81 & 0 \\
\hline 27 & 7 & 2 & 12.6 & 25.6 & 25.3 & 25.2 & 25.4 & 7.75 & 32.73 & 0 \\
\hline 27 & 7 & 3 & 12.5 & 20.4 & 20.7 & 20 & 20.4 & 7.65 & 26.62 & 0 \\
\hline 27 & 7 & 4 & 12.6 & 18.5 & 18.6 & 18.6 & 18.6 & 7.75 & 23.96 & 0 \\
\hline 27 & 7 & 5 & 12.5 & 18.2 & 18.3 & 18.3 & 18.3 & 7.65 & 23.88 & 0 \\
\hline 27 & 8 & 1 & 12.4 & 26.2 & 27.1 & 26.6 & 26.6 & 7.55 & 35.28 & 0 \\
\hline 27 & 8 & 2 & 12.4 & 41.5 & 41.7 & 41.2 & 41.5 & 7.55 & 54.92 & 0 \\
\hline 27 & 8 & 3 & 12.6 & 58.8 & 59 & 58.6 & 58.8 & 7.75 & 75.87 & 0 \\
\hline 27 & 8 & 4 & 12.6 & 34.1 & 33.9 & 33.7 & 33.9 & 7.75 & 43.74 & 0 \\
\hline 27 & 8 & 5 & 12.5 & 20.4 & 20.4 & 20.5 & 20.4 & 7.65 & 26.71 & 0 \\
\hline
\end{tabular}


Table A-4. Site Level Soil Susceptibility Values

\begin{tabular}{|c|c|c|c|c|c|c|c|c|c|}
\hline Site & Shovel Test & Level & Weight (g) & Adjusted wt. & Read 1 & Read 2 & Read 3 & Average & MSS Value \\
\hline 41BR499 & 1 & 1 & 12.4 & 7.55 & 47.2 & 48.1 & 48.1 & 47.8 & 63.31 \\
\hline 41BR499 & 1 & 2 & 12.2 & 7.35 & 44.8 & 44.1 & 44.3 & 44.4 & 60.41 \\
\hline 41BR499 & 1 & 3 & 12.1 & 7.25 & 43.6 & 43.3 & 43.4 & 43.4 & 59.91 \\
\hline 41BR499 & 1 & 4 & 12.5 & 7.65 & 45.3 & 45.4 & 45.1 & 45.3 & 59.17 \\
\hline 41BR499 & 1 & 5 & 12.6 & 7.75 & 39.2 & 39.1 & 39.4 & 39.2 & 50.62 \\
\hline 41BR499 & 2 & 1 & 11.4 & 6.55 & 44.3 & 44.4 & 44.1 & 44.3 & 67.58 \\
\hline 41BR499 & 2 & 2 & 11.3 & 6.45 & 41.8 & 42.1 & 41.5 & 41.8 & 64.81 \\
\hline 41BR499 & 2 & 3 & 10.6 & 5.75 & 34.4 & 36.7 & 36.8 & 36.0 & 62.55 \\
\hline 41BR499 & 2 & 4 & 11.5 & 6.65 & 42.2 & 42.7 & 42.5 & 42.5 & 63.86 \\
\hline 41BR499 & 2 & 5 & 11.9 & 7.05 & 38.6 & 38.9 & 38.7 & 38.7 & 54.94 \\
\hline 41BR500 & 1 & 1 & 12.3 & 7.45 & 53.9 & 53.8 & 54.1 & 53.9 & 72.39 \\
\hline 41BR500 & 1 & 2 & 11.1 & 6.25 & 46.9 & 47.1 & 47.5 & 47.2 & 75.47 \\
\hline 41BR500 & 1 & 3 & 11.2 & 6.35 & 47.9 & 48.4 & 48.1 & 48.1 & 75.80 \\
\hline $41 \mathrm{BR} 500$ & 1 & 4 & 11.5 & 6.65 & 46.8 & 47.4 & 47.7 & 47.3 & 71.13 \\
\hline $41 \mathrm{BR} 500$ & 1 & 5 & 12.1 & 7.25 & 52.8 & 53.4 & 52.9 & 53.0 & 73.15 \\
\hline 41BR500 & 2 & 1 & 12.1 & 7.25 & 36.9 & 36.6 & 36.7 & 36.7 & 50.67 \\
\hline 41BR500 & 2 & 2 & 11.7 & 6.85 & 52.9 & 53.1 & 52.8 & 52.9 & 77.27 \\
\hline 41BR500 & 2 & 3 & 12.3 & 7.45 & 47 & 47.1 & 47.2 & 47.1 & 63.22 \\
\hline $41 \mathrm{BR} 500$ & 2 & 4 & 11.9 & 7.05 & 40.3 & 40 & 39.8 & 40.0 & 56.78 \\
\hline $41 \mathrm{BR} 500$ & 2 & 5 & 11.7 & 6.85 & 37.8 & 37.9 & 37.8 & 37.8 & 55.23 \\
\hline 41BR500 & 3 & 1 & 12 & 7.15 & 33.1 & 33.6 & 33.6 & 33.4 & 46.76 \\
\hline 41BR500 & 3 & 2 & 12.3 & 7.45 & 36.4 & 36.6 & 36.6 & 36.5 & 49.04 \\
\hline $41 \mathrm{BR} 500$ & 3 & 3 & 11.5 & 6.65 & 38.5 & 38.6 & 38.7 & 38.6 & 58.05 \\
\hline 41BR500 & 3 & 4 & 11.9 & 7.05 & 39.7 & 39.9 & 40 & 39.9 & 56.55 \\
\hline 41BR500 & 3 & 5 & 12.1 & 7.25 & 38.8 & 39.4 & 39 & 39.1 & 53.89 \\
\hline 41BR500 & 4 & 1 & 12.2 & 7.35 & 34.7 & 34.8 & 34.8 & 34.8 & 47.30 \\
\hline 41BR500 & 4 & 2 & 11.3 & 6.45 & 40.2 & 40.4 & 40.5 & 40.4 & 62.58 \\
\hline 41BR500 & 4 & 3 & 11.1 & 6.25 & 47.4 & 46.9 & 47.2 & 47.2 & 75.47 \\
\hline 41BR500 & 4 & 4 & 12.3 & 7.45 & 55.4 & 55.7 & 55.2 & 55.4 & 74.41 \\
\hline 41BR500 & 4 & 5 & 12.4 & 7.55 & 49.4 & 49.5 & 49.7 & 49.5 & 65.61 \\
\hline 41BR500 & 5 & 1 & 11.5 & 6.65 & 44.2 & 44 & 44 & 44.1 & 66.27 \\
\hline 41BR500 & 5 & 2 & 11.8 & 6.95 & 55.9 & 56.2 & 55.8 & 56.0 & 80.53 \\
\hline 41BR500 & 5 & 3 & 12.1 & 7.25 & 59.1 & 59.3 & 59 & 59.1 & 81.56 \\
\hline 41BR500 & 5 & 4 & 12.1 & 7.25 & 57.1 & 57.5 & 57.2 & 57.3 & 78.99 \\
\hline 41BR500 & 5 & 5 & 11.9 & 7.05 & 52.2 & 52.3 & 52.7 & 52.4 & 74.33 \\
\hline 41BR500 & 6 & 1 & 11.5 & 6.65 & 17 & 17.8 & 17.6 & 17.5 & 26.27 \\
\hline 41BR500 & 6 & 2 & 11.8 & 6.95 & 26 & 26 & 26 & 26.0 & 37.41 \\
\hline $41 \mathrm{BR} 500$ & 6 & 3 & 11.4 & 6.55 & 33.5 & 33.5 & 33.5 & 33.5 & 51.15 \\
\hline $41 \mathrm{BR} 500$ & 6 & 4 & 11.8 & 6.95 & 32.1 & 32 & 32.1 & 32.1 & 46.14 \\
\hline 41BR500 & 6 & 5 & 11.9 & 7.05 & 46.1 & 47.3 & 46.9 & 46.8 & 66.34 \\
\hline 41BR500 & 7 & 1 & 11.6 & 6.75 & 34.7 & 34.6 & 35 & 34.8 & 51.51 \\
\hline 41BR500 & 7 & 2 & 12 & 7.15 & 143.4 & 144.3 & 144.2 & 144.0 & 201.35 \\
\hline 41BR500 & 7 & 3 & 11.9 & 7.05 & 83.1 & 82.4 & 81.8 & 82.4 & 116.93 \\
\hline $41 \mathrm{BR} 500$ & 7 & 4 & 12.3 & 7.45 & 54.3 & 54.1 & 54.5 & 54.3 & 72.89 \\
\hline $41 \mathrm{BR} 500$ & 7 & 5 & 12.4 & 7.55 & 41 & 41.1 & 40.8 & 41.0 & 54.26 \\
\hline 41BR500 & 8 & 1 & 12.7 & 7.85 & 37.7 & 37.6 & 37.8 & 37.7 & 48.03 \\
\hline 41BR500 & 8 & 2 & 11.5 & 6.65 & 38 & 38.1 & 38.1 & 38.1 & 57.24 \\
\hline
\end{tabular}


Table A-4. continued...

\begin{tabular}{|c|c|c|c|c|c|c|c|c|c|}
\hline Site & Shovel Test & Level & Weight (g) & Adjusted wt. & Read 1 & Read 2 & Read 3 & Average & MSS Value \\
\hline 41BR500 & 8 & 3 & 13.1 & 8.25 & 46 & 46.1 & 46.2 & 46.1 & 55.88 \\
\hline 41BR500 & 8 & 4 & 11.7 & 6.85 & 23.6 & 24.1 & 23.9 & 23.9 & 34.84 \\
\hline 41BR500 & 8 & 5 & 12.5 & 7.65 & 32.3 & 32.8 & 33.4 & 32.8 & 42.92 \\
\hline 41BR501 & 1 & 1 & 11.9 & 7.05 & 35.3 & 35.6 & 35.5 & 35.5 & 50.31 \\
\hline 41BR501 & 1 & 2 & 12 & 7.15 & 33.2 & 34.5 & 34.5 & 34.1 & 47.65 \\
\hline 41BR501 & 1 & 3 & 12.1 & 7.25 & 35.6 & 35.4 & 35.4 & 35.5 & 48.92 \\
\hline 41BR501 & 1 & 4 & 11.9 & 7.05 & 35.1 & 34.9 & 35.4 & 35.1 & 49.83 \\
\hline 41BR501 & 1 & 5 & 11.7 & 6.85 & 49.6 & 49.7 & 50 & 49.8 & 72.65 \\
\hline 41BR501 & 2 & 1 & 11.5 & 6.65 & 33 & 33.4 & 33.1 & 33.2 & 49.87 \\
\hline 41BR501 & 2 & 2 & 12.5 & 7.65 & 42.7 & 43 & 42.8 & 42.8 & 55.99 \\
\hline 41BR501 & 2 & 3 & 10.1 & 5.25 & 27.3 & 27.4 & 27.2 & 27.3 & 52.00 \\
\hline 41BR501 & 2 & 4 & 12.8 & 7.95 & 44.3 & 44.3 & 44.1 & 44.2 & 55.64 \\
\hline 41BR501 & 2 & 5 & 12.5 & 7.65 & 38.6 & 38.8 & 38.8 & 38.7 & 50.63 \\
\hline
\end{tabular}




\section{References Cited}

Collins, M. B., W. A. Gose, and S. Shaw

1994 Preliminary Geomorphological Findings at Dust and Nearby Caves. Journal of Alabama Archaeology 40:35-56.

Dearing, J.

1999 Environmental Magnetic Susceptibility. Chi publishing, Kenilworth, England.

Gose, W. A., and D. L. Nickels

2001[1998] Archaeomagnetic and Magnetic Susceptibility Analyses. In Test Excavations at the Culebra Creek Site, 41BX126, Bexar County, Texas, by D. L. Nickels, C. B. Bousman, J. D. Leach, and D. A. Cargill, pp. 204-214. Archaeological Survey Report, No. 265, Center for Archaeological Research, The University of Texas at San Antonio; Archeology Studies Program, Report 3, Environmental Affairs Division, Texas Department of Transportation, Austin.

McClean, R. G., and W. F. Kean

1993 Contributions of Wood Ash Magnetism to Archeomagnetic Properties of Fire Pits and Hearths. Earth and Planetary Science Letters 119:387-394.

Reynolds, R. L., and J. W. King

1995 Magnetic Records of Climate Change. U.S. National Report to I.U.G.G., 1991-1994. American Geophysical Union. <http://www.agu.ong/revgeophys/reyno100/reyno100.html> Viewed April 2001.

Singer, M. J., and P. Fine

1989 Pedogenic Factors Affecting Magnetic Susceptibility of Northern California Soils. Soil Science of America Journal 53:1119-1127. 